\title{
Environmental Assessment Methodology for the Nuclear Fuel Cycle
}

D. L. Brenchley

J. K. Soldat

J. A. McNeese

E. C. Watson

July 1977

Prepared for the Energy Research

and Development Administration

under Contract EY-76-C-06-1830

\section{Baltelle}


NOTICE

This report was prepared as an account of work sponsored by the United States Government. Neither the United States nor the Energy Research and Development Administration, nor any of their employees, nor any of their contractors, subcontractors, or thetr empioyees, makes any warranty, express or implied, or assumes any lega! liability or responsibility for the accuracy, completeness or usefulness of any information, apparatus, product or process disc'osed, or represents that its use would not infringe privately owned rights.

PACIFIC NORTHWEST LABORATORY

operated by

BATTELLE

for the

ENERGY RESEARCH AND OEVELOPMENT ADMINISTRATION

Linder Contract EY-76-C-06-1830

\author{
Printed in the United sraces of Noreflica \\ Available from \\ vatuondi Technical information Service \\ U.5. Department of Commerce \\ 5285 Port Royal Road \\ Springnield, Virg nia 2757
}

Frice: Priated Copy

: Microliche $\$ 3.00$

\begin{tabular}{|c|c|}
\hline "Pages & $\begin{array}{c}\text { NTIS } \\
\text { Seltirg Price }\end{array}$ \\
\hline $007-925$ & 5450 \\
\hline 0.6 .050 & $\$ 5.00$ \\
\hline $051-075$ & 55.50 \\
\hline $076-700$ & 55.00 \\
\hline $101-125$ & 56.50 \\
\hline $126-150$ & 57.00 \\
\hline $157-7-75$ & 37.75 \\
\hline $176-200$ & $\$ 6.50$ \\
\hline 201.225 & $\$ 8.75$ \\
\hline $226-250$ & 59.00 \\
\hline 251.275 & 570.00 \\
\hline $276-300$ & 510.25 \\
\hline
\end{tabular}


ENVIRONMENTAL ASSESSMENT METHODOLOGY

FOR THE NUCLEAR FUEL CYCLE

\footnotetext{
by

D. L. Brenchley

J. K. Soldat

J. A. McNeese

E. C. Watson
}

Ju1y 1977

\section{BATTELLE}

Pacific Northwest Laboratories

Richland, Washington 99352 


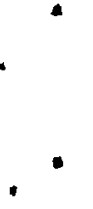

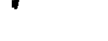

4

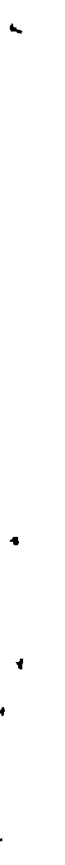

? , 
The remaining reports will describe the nuclear fuel cycle facilities to be studied and the results of our analyses.

These reports are all available from the National Technical Information Service.

T. J. Kabele

Project Manager 

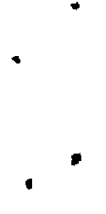


\section{PREFACE}

The operation of nuclear fuel cycle facilities will introduce noxious materials, both radiological and chemical, into the environment through routine discharges of both liquid and airborne effluents. The environmental implications of continued development of existing nuclear fuel cycles and implementation of new fuel cycles must be determined systematically to assure the timely development and demonstration of technologies which control or eliminate the discharge of these materials.

To address this need for a comprehensive systems analysis of effluent control technologies for the nuclear fuel cycles, ERDA's Division of Environmental Control Technology has funded a program, Analysis of Nuclear Fuel Cycles, at Battelle, Pacific Northwest Laboratory (PNL). The objective of this program is to identify areas in developing nuclear fuel cycles (1) where environmental controls seem to be inadequate, (2) where inconsistencies and conflicts exist in environmental policy, and (3) where improved environmental controls can be justified on a cost/benefit basis (i.e., ensure that funds are not expended in cases where neither potential effects nor public concerns warrant such expenditures). The program initially focuses on current and "near future" LWR effluent control technology. Later work will focus on cost/benefit analyses of effluent control technologies for advanced LWR alternative fuel cycles and for LMFBR fuel cycles. Further work will concentrate on analyzing other advanced nuclear energy systems (e.g., thorium, fusion) and integrating results from the various energy technology studies to evaluate the total status of environmental control technology for the nuclear industry.

The key elements in the program are:

- A computer code which permits calculation of mass balances of some 500 materials in a given fuel cycle as a function of time and projected electrical energy demand 
- A cost analysis of each facility in a given fuel cycle (both capital and operating costs)

- An environmental assessment analysis for each effluent in a given fuel cycle which compares calculated effluent rates with current and projected NRC and EPA standards

- An analysis which ties the preceding three elements into a single evaluation of effluent control technologies for a given fuel cycle.

The outputs of this program will be a series of reports which:

- Identify the effluents from and the control technologies for a series of nuclear fuel cycles

- Define problem areas where current effluent control technologies will not be adequate to meet existing or proposed effluent standards

- Evaluate alternative effluent control technologies for application to those nuclear fuel cycle effluents which were defined as having inadequate controls

- Recommend improvements in specific effluent control technolgies, including new research and. new applications of existing technology.

This report is one of approximately ten that will be published during the course of the program. The first three reports to be published describe the analytical tools used in the study. Since these analytical methodologies have applications far beyond the scope of this study, they deserve special attention, particularly by those engaged in environmental analyses and cost/benefit studies of environmental impacts. These documents are:

ENFORM: An ENergy InFORMation System, BNWL-2195, by C. M. Heeb, W. L. Purcell, and B. M. Cole.

Procedures for Estimating Nuclear Fuel Cycle Costs, BNWL-2110, by John Young.

Environmental Assessment Methodology for the Nuclear Fuel Cycle, BNWL-2219, by D. L. Brenchley, J. K. Soldat, J. A. Mcneese and E. C. Watson. 
This report describes the methodology for determining where environmental control technology is required for the nuclear fuel cycle. This methodology must satisfy four main requirements, which together make up the environmental assessment. It must:

- identify any effluents that exceed environmental standards

- assess the impact of effluents for which no environmental standards exist and identify any potentially hazardous effluents

- estimate the level of control efficiency required for each effluent's source (industrial activity or process)

- rank effluents emitted from each nuclear fuel cycle facility according to their relative environmental impact.

The methodology addresses routine emission of chemical and radioactive effluents, and applies to mining, milling, conversion, enrichment, fuel fabrication, reactors (LWR and BWR) and fuel reprocessing. Chemical and radioactive effluents are evaluated independently. Radioactive effluents are evaluated on the basis of maximum exposed individual dose and population dose calculations for a 1-year emission period and a 50-year commitment. Sources of radionuclides for each facility are then listed according to their relative contribution to the total calculated dose.

Effluent, ambient and toxicology standards are used to evaluate the effect of chemical effluents. First, each chemical and source configuration is determined. Sources are tagged if they exceed existing standards. The combined effect of a 11 chemicals is assessed for each facility. If the additive effects are unacceptable, then additional control technology is recommended. Finally, sources and their chemicals at each facility are ranked according to their relative contribution to the ambient pollution level. This ranking identifies those sources most in need of environmental control. 
The assessment methodology is subject to several important limitations which should be considered when making subsequent calculations, evaluations and recommendations. They include:

- The method assumes chemical and radioactive effiuents may be treated independently.

- Accidental releases and occupational exposure are not evaluated.

- Calculation procedures for estimating concentrations and doses are at best accurate within a factor of 10 .

- Calculation procedures do not directly estimate health and welfare effects.

- The effect of radioactive and chemical effluents on groundwater quality is not evaluated.

- The effects of solid waste and thermal discharges are not evaluated. 


\section{CONTENTS}

PREFACE

SUMMARY

INTRODUCTION

ASSESSMENT METHODOLOGY FOR RADIOACTIVE EFFLUENTS . . . . . . . . 3

DOSE CALCULATION METHODS . . . . . . . . . . . . . . 3

DOSE TO MAN - BASIC CONSIDERATIONS . . . . . . . . . . 5

Concentrations of Nuclides in Environmental Media, $\mathrm{C}_{\mathrm{ip}} \cdot{ } \cdot 7$

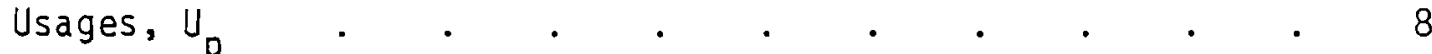

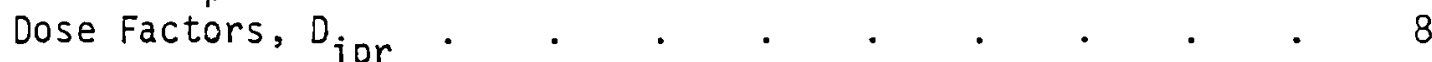

DOSE TO MAN - LIQUID PATHWAYS . . . . . . . . . . . . . 11

Drinking Water. $. \quad . \quad . \quad . \quad . \quad . \quad . \quad . \quad . \quad 11$

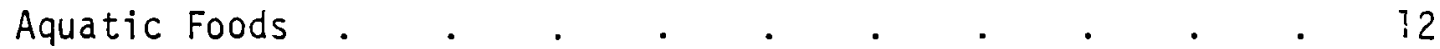

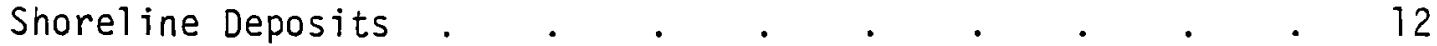

Swimming and Boating . . . . . . . . . . . 15

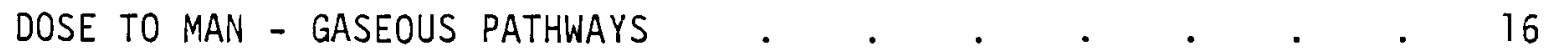

Air Submersion .

Doses from Inhalation . . . . . . . . . . . 17

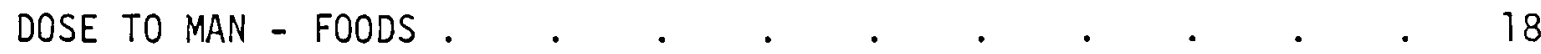

Deposition on Food Products . . . . . . . . . . . 19

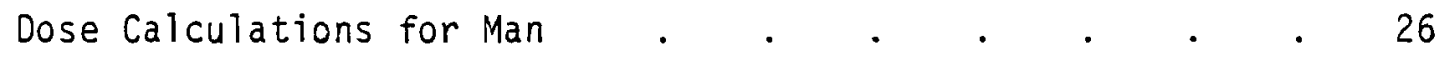

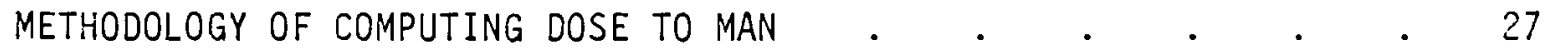

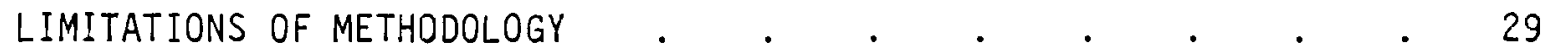

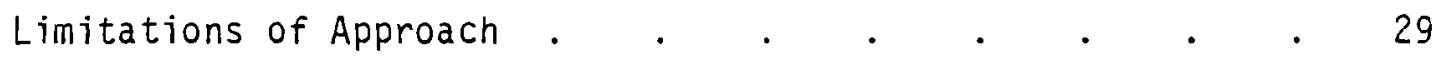

Quality of Data . . . . . . . . . . . . . 30

Accuracy of Calculation Procedures . . . . . . . . 30

ASSESSMENT METHODOLOGY FOR CHEMICAL EFFLUENTS . . • . • • . 31

THE APPROACH . . . . . . . . . . . . . . . . 32

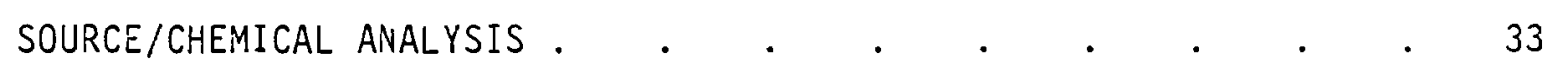

Methodology Based on Effluent Standards . . . . . . 33

Methodology Based on Ambient Standards . . . . . . . 35

Methodology Based on Toxicological Standards and Data . . 39 


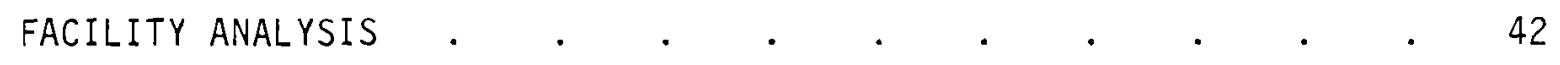

Multiple Chemical Effects . . . . . . . . 42

Large-Scale Effects. . . . . . . . . . . . . 45

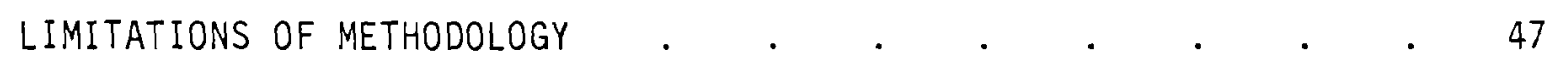

Limitations of Approach . . . . . . . . . . . . 47

Quality of Data . . . . . . . . . . . . . . . 47

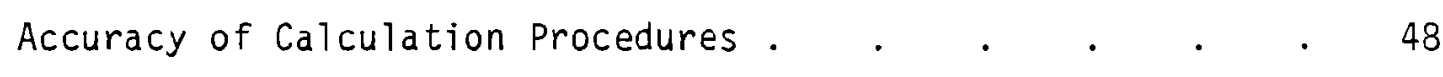

REFERENCES

APPENDIX A - ENVIRONMENTAL STANDARDS FOR RADIOACTIVE EFFLUENTS

APPENDIX B - ENVIRONMENTAL STANDARDS FOR GASEOUS CHEMICAL EFFLUENTS

APPENDIX $C$ - ENVIRONMENTAL STANDARDS FOR LIQUID CHEMICAL EFFLUENTS

APPENDIX D - REVIEW OF ENVIRONMENTAL ASSESSMENT METHODOLOGIES FOR CHEMICAL EFFLUENTS 


\section{$\underline{\text { TABLES }}$}

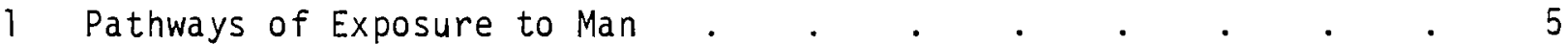

2 Programs for Calculating Radiation Doses . . . . . . . 6

3 Nuclides for Which Dose Factors are Currently Available . . 10

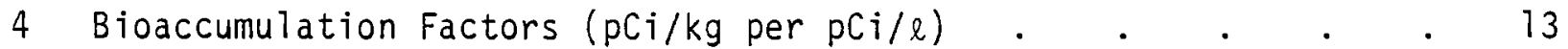

5 Shore Width Factors Used in Eq. (5) and Eq. (6) . . . . . 15

6 Consumption Rates of Feed and Water by Farm Animals . 22

$7 \quad$ Plant Concentration Factors and Animal Product

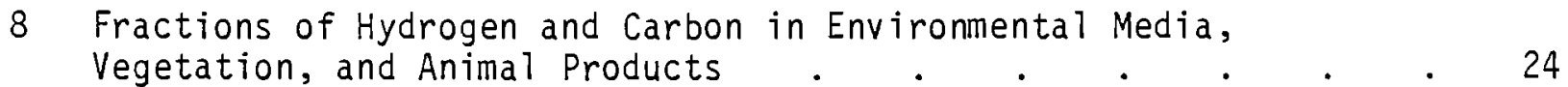

\begin{tabular}{l}
9 Increases in Air Pollution that Represent Significant \\
Deterioration . \\
\hline
\end{tabular} 


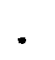

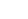

• 


\section{INTRODUCTION}

Nuclear fuel cycle facilities are subject to an increasing number of environmental regulations. Present and future facilities must comply with these regulations if nuclear power is to expand its role in meeting electrical power demands. Furthermore, the cost of compliance must not appreciably alter the cost of electricity. An environmental assessment is required to estimate the need for environmental control technology for the complete LWR fuel cycle covering periods of 30 to 100 years in the future. Once this assessment is completed, sources requiring new or improved environmental control technology can be identified and the environmental control costs can be estimated.

Battelle, Pacific Northwest Laboratory (PNL) is preparing a document which describes the nuclear fuel cycle facilities, including the processes, raw materials, products and effluents, and sites for each of the following facilities:

Mining

Milling

Conversion

Enrichment

Fuel Fabrication

Reactors

Fuel Reprocessing surface mine underground mine

acid leach and solvent extraction process to produce ammonium diuranate (yellow cake)

aqueous conversion process to produce uranium hexafluoride

process for power reactor enrichment using uranium hexafluoride from conversion plant

uranium dioxide facility uranium dioxide/plutonium dioxide facility

PWR reactor

BWR reactor

modeled after Barnwell, SC facility

The fuel cycle and facility descriptions represent conditions that are typical today or are expected to be typical in the near future. Actual facilities were selected wherever possible to ensure realistic descriptions. 
Two site descriptions have been developed in the PNL study for use with the facilities. Once applies to the mine and the mill; the second applies to all of the other facilities. These site descriptions provide meteorological, hydrological and demographic data. The descriptions define all surface waters; identify topographical features; provide wind speed, wind direction and air quality data; and provide population distribution data.

The facility descriptions provide the necessary information for environmental assessment work. The PNL study has generated lists of radioactive and chemical effluents for each facility; these are tabulated in Appendices $A$, $B$ and $C$. The description of the various processes also provides emission factors (not given here) for each species; these data, along with the site description, provide the necessary input for exposure and dose calculations. 


\section{ASSESSMENT METHODOLOGY FOR RADIOACTIVE EFFLUENTS}

The objective of this environmental assessment is to define and rank the needs for controlling radioactive effluents from nuclear fuel cycle facilities. The assessment will be based on environmental standards (see Appendix A) and dose-to-man calculations.

The study will make three calculations for each isotope from each facility:

- Maximum individual dose for a 50-yr dose commitment from a 1-yr exposure according to the organ affected.

- Population dose for a 50-yr dose commitment from a 1-yr exposure according to the organ affected.

- Annual dose rate for the maximally exposed individual.

The relative contribution of a specific nuclide and source to the total dose provides a method of ranking the nuclides, which in turn identifies the sources that should receive the greatest control in the future. These results will be used in subsequent tasks to assess the environmental impact of the total nuclear fuel cycle.

\section{DOSE CALCULATION METHODS}

Evaluation of radiological impacts must be included in any comparison of fuel cycle alternatives. To evaluate the radiological impacts of fuel cycle alternatives, exposure paths to man must first be identified. The major pathways by which man can be exposed to radiation from a nuclear facility are illustrated in Figure 1. The exposure pathways can be grouped into those associated with gaseous effluents, those associated with liquid effluents, and those associated with exposure to direct radiation from the facility or from transportation of radioactive materials to or from the 


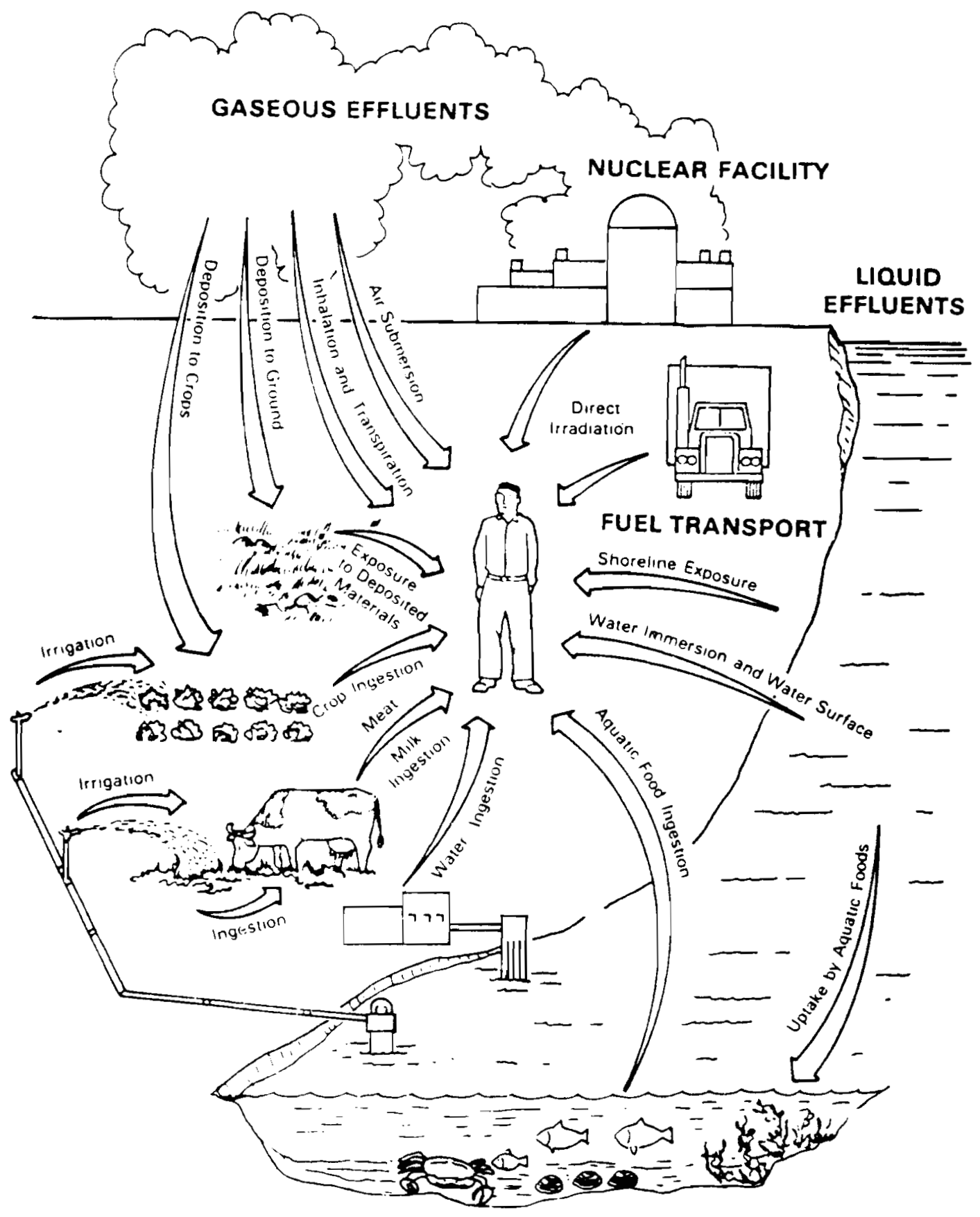

FIGURE 1. Exposure Pathways to Man 
facility (Table 1). Calculations for each pathway are then made for those selected organs which could potentially receive the highest radiation dose. Some of the programs developed at PNL for calculating radiation doses from radionuclides in the environment are described in Table 2.

\section{TABLE 1. Pathways of Exposure to Man}

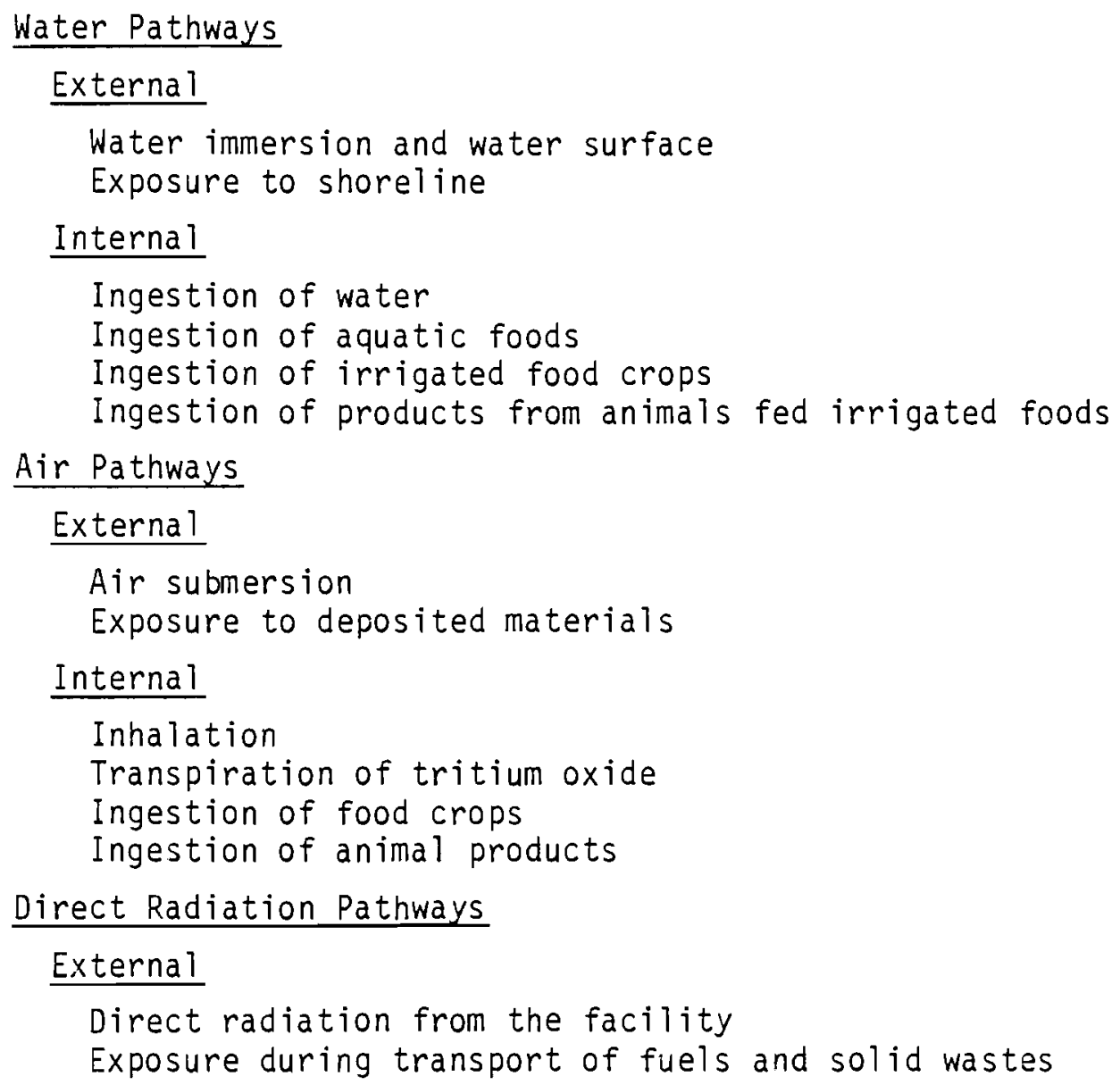

DOSE TO MAN - BASIC CONSIDERATIONS

The fundamental equation for calculating radiation dose rate from the pathways listed in Table 1 is

$$
R_{i p r}=C_{i p} U_{p} D_{i p r}
$$




\section{TABLE 2. Programs for Calculating Radiation Doses}

\begin{tabular}{|c|c|c|c|}
\hline Program & Item Calculated & Organ Doses Calculated & Reference \\
\hline \multirow[t]{4}{*}{ ARRRG } & $\begin{array}{l}\text { Individual and population doses from } \\
\text { ingested water }\end{array}$ & $\begin{array}{l}\text { Annual dose to total body, } \\
\text { GI-LLI, } a \text { g thyroid, bone, } \\
\text { liver, kidney }\end{array}$ & BNWL-1754(1) \\
\hline & $\begin{array}{l}\text { Individual and population doses from } \\
\text { aquatic foods (fish, crustacea, } \\
\text { molluscs, plants) }\end{array}$ & $\begin{array}{l}\text { Annual dose to total body, } \\
\text { GI-LLI, thyroid, bone, liver, } \\
\text { kidney }\end{array}$ & \\
\hline & $\begin{array}{l}\text { Individual and population doses from } \\
\text { sediment exposure (shoreline) }\end{array}$ & $\begin{array}{l}\text { Annual dose to skin, total } \\
\text { body }(b)\end{array}$ & \\
\hline & $\begin{array}{l}\text { Individual and population doses from } \\
\text { swimming and boating }\end{array}$ & $\begin{array}{l}\text { Annual dose to skin, total } \\
\text { body (b) }\end{array}$ & \\
\hline \multirow[t]{2}{*}{ FOOD } & $\begin{array}{l}\text { Concentrations in produce, milk, eggs, } \\
\text { meat from aerial deposition or irriga- } \\
\text { tion at specified location }\end{array}$ & --- & $\begin{array}{l}B N W L-S A-5523(2) \\
B N W L-2209(3)\end{array}$ \\
\hline & $\begin{array}{l}\text { Individual doses from ingestion of } \\
\text { farm products }(c)\end{array}$ & $\begin{array}{l}\text { Annual dose to total body, } \\
\text { GI-LLI, thyroid, bone, liver, } \\
\text { lung, kidney }\end{array}$ & \\
\hline \multirow[t]{4}{*}{ VITTLS $(d)$} & $\begin{array}{l}\text { Concentrations on soil from aerial } \\
\text { deposition or irrigation at specified } \\
\text { locations }\end{array}$ & -- & --- \\
\hline & $\begin{array}{l}\text { Individual doses from exposure to } \\
\text { soil }(c)\end{array}$ & $\begin{array}{l}\text { Annual dose and dose commit- } \\
\text { ment to skin, total body }(b)\end{array}$ & \\
\hline & $\begin{array}{l}\text { Concentrations in produce, milk, eggs, } \\
\text { meat from aerial deposition or irriga- } \\
\text { tion at specified location }\end{array}$ & -- & \\
\hline & $\begin{array}{l}\text { Individual doses from ingestion of } \\
\text { farm products }(\mathrm{c})\end{array}$ & $\begin{array}{l}\text { Annual dose to total body, } \\
\text { GI-LLI, thyroid, bone, liver, } \\
\text { lung, kidney }\end{array}$ & \\
\hline \multirow[t]{4}{*}{ GRONK } & $\begin{array}{l}\text { Annual average atmospheric dilution } \\
\text { factors ( } \mathrm{C} / \mathrm{m} 3 \text { per Ci/sec released) } \\
\text { versus distance and direction from } \\
\text { the source }\left(\bar{X} / \mathrm{Q}^{\prime}\right)\end{array}$ & -- & BNWL-1754(1) \\
\hline & $\begin{array}{l}\text { Individual doses from exposure to half- } \\
\text { infinite cloud of effluents, versus } \\
\text { distance and direction from the source }\end{array}$ & $\begin{array}{l}\text { Annual dose to skin, total } \\
\text { body }\end{array}$ & \\
\hline & $\begin{array}{l}\text { Integrated man-rem doses to total } \\
\text { population within } 50 \text { miles }\end{array}$ & Annual dose to total body & \\
\hline & $\begin{array}{l}\text { Doses to child and adult from inhala- } \\
\text { tion, and consumption of milk and } \\
\text { leafy vegetables }\end{array}$ & Annual dose to thyroid & \\
\hline \multirow[t]{3}{*}{ GAUCHE } & $\begin{array}{l}\text { Individual doses from air submersion } \\
\text { at a specified location }\end{array}$ & $\begin{array}{l}\text { Annual dose and dose commit- } \\
\text { ment to skin and total body }\end{array}$ & -- \\
\hline & $\begin{array}{l}\text { Individual doses from inhalation and } \\
\text { tritium transpiration at a specified } \\
\text { location(c) }\end{array}$ & $\begin{array}{l}\text { Annual jose and dose commit- } \\
\text { ment to total body, GI-LLI, } \\
\text { thyroid, bone, liver, kidney }\end{array}$ & $\rightarrow$ \\
\hline & $\begin{array}{l}\text { Doses to child and adult from inhala- } \\
\text { tion, and consumption of milk and } \\
\text { leafy vegetables, at any specified } \\
\bar{x} / Q^{\prime}\end{array}$ & Annual dose to thyroid & \\
\hline
\end{tabular}

(a) GI-LLI means gastrointestinal tract-lower large intestine.

(b) For these pathways, the calculated total-body dose is also listed under organs other than skin on the printout and is added into the total dose to these organs.

(c) Population doses can be calculated by using population weighted average input data.

(d) VITTLS also calculates the same internal doses as does FOOD, plus dose commitments. 
where

$$
\begin{aligned}
& R_{i p r} \text { is the dose rate to organ } r \text { from nuclide } i \text { via pathway } p \text {, } \\
& C_{i p} \text { is the concentration of nuclide } i \text { in the medium pathway } p \text {, } \\
& U_{p} \text { is the usage: the exposure or intake rate associated with pathway } p \text {, } \\
& \text { and } \\
& D_{i p r} \text { is the dose rate factor: a number specific to a given nuclide } i, \\
& \text { pathway } p \text {, and organ } r \text { which can be used to calculate radiation } \\
& \text { dose rate from exposure to a given radionuclide concentration or a } \\
& \text { radionuclide intake. }
\end{aligned}
$$

Equation (1) can also be used to calculate a dose commitment, rather than a dose rate by using a dose commitment factor in place of a dose rate factor. A dose commitment factor is defined as the dose delivered to an organ over 50 years per unit intake of a nuclide during the first year, including the dose delivered the year of intake.

Equations tailored to each specific exposure pathway are derived from this equation. The principal difference between pathways is the manner in which the radionuclide concentrations are calculated. The three terms on the right of the equation are discussed in the following subsections.

\section{Concentrations of Nuclides in Envirormental Media, $\mathrm{C}_{i p}$}

Concentrations of nuclides in air, water soil or food are calculated as intermediate steps in the computer programs. Concentrations in water, in aquatic foods, and on shoreline sediment are calculated from the radionuclide release rates, the effluent flow rate, the mixing and dilution in the receiving waters, and bioaccumulation factors for aquatic foods. Concentrations in air and on vegetation from aerial deposition are calculated from radionuclide release rates and from equations for atmospheric dispersion.

Concentrations of nuclides in irrigated farm produce are calculated from concentrations of radionuclides in the irrigation water, irrigation rate, facility lifetime (which determines long-term soil buildup), and decay time between nuclide release and produce consumption. 
$\underset{\text { Usages, } U_{p}}{\longrightarrow}$

Usage refers to duration of exposure to external sources of radiation and to intake rates of ingested water and food. For pathways other than air submersion, the usage depends on the specific situation. Since noble gases are the principal contributors to air submersion dose, the air concentrations of radionuclides are assumed to be essentially the same indoors as outdoors. Thus, no shielding and occupancy factors are applied, and $8766 \mathrm{hr} / \mathrm{yr}$ is used for the air submersion pathway.

In the absence of site-specific data, average usages and exposure times can be used to calculate individual adult doses. $(1,4)$ For calculating population dose the usages of the average adult are multiplied by the size of the population.

Dose Factors, $\mathrm{D}_{\mathrm{ipr}}$

Equations for calculating internal dose rate factors as defined in Equation (1) have been published. $(5,6)$ They were derived originally from those given by the International Commission on Radiological Protection (ICRP) $(7)$ for body burden and maximum permissible concentration. For this study, effective decay energies for the radionuclides are calculated from the ICRP model, which assumes that all of the radionuclide is at the center of a spherical organ with an appropriate effective radius. Where data are lacking, metabolic parameters for the Standard Man (7) are used for other ages as well. Internal dose rate factors have units of mrem/yr per $\mathrm{pCi} / \mathrm{yr}$ intake via ingestion or inhalation, and represent the first year's dose from 1-yr chronic intake.

Dose commitment factors have units of mrem over 50 yr per $\mathrm{PC} i$ intake during the first year and include the dose during the year of intake. (Periods other than $50 \mathrm{yr}$ can be used for the dose commitment calculations.)

For calculating external dose rate factors from air submersion or water immersion, the penetrating power of the radiation emitted determines whether it contributes to skin dose only, or to both skin and total body dose. 
Beta and gamma radiation which can penetrate $7 \times 10^{-3} \mathrm{~cm}$ of tissue is considered to contribute to skin dose; that which can penetrate $5 \mathrm{~cm}$ of tissue is considered to contribute to total body dose (and dose to internal organs). The dose rate factors for air submersion and water immersion are derived by assuming that the contaminated medium is an infinite volume compared to the range of the emitted radiations. Under this assumption the energy emitted per gram of medium equals the energy absorbed per gram of medium. Corrections must be applied for differences in energy absorption between tissue and air or water, physical geometry of the specific exposure situation and the conversion from MeV per disintegration per gram to rem. The resulting dose rate factors have units of $\mathrm{mrem} / \mathrm{hr}$ per $\mathrm{pCi} / \mathrm{m}^{3}$ of air or $\mathrm{mrem} / \mathrm{hr}$ per $\mathrm{pCi} / \ell$ of water. There is no additional external dose contribution from air or water after the 1-yr exposure.

Material deposited from the air or from irrigation water onto the ground represents a fairly large, nearly uniform, thin sheet of contamination. The factors for converting surface contamination in $\mathrm{pCi} / \mathrm{m}^{2}$ to gamma dose at $1 \mathrm{~m}$ above a uniformly contaminated plane are described in References 1, 5, and 6 . Dose rate factors for exposure to soil (or river sediment) have units of $\mathrm{mrem} / \mathrm{hr}$ per $\mathrm{pCi} / \mathrm{m}^{2}$ of surface. A dose commitment could be calculated for soil exposure by accounting for the contamination remaining on the surface after the year of deposition is over; this capability exists in the VITTLS computer program. Dose rate factors have been generated for nearly 200 radionuclides (Table 3 ) and are periodically recalculated using the latest available decay schemes. Also, first-year dose rate and 50-yr dose commitment factors have been calculated for adults for a single (acute) intake of the radionuclides via ingestion and inhalation. These factors are intended for assessing releases and therefore have not been entered into the programs for routine dose calculation.

The standard format for making calculations proposed by the U.S. Nuclear Regulatory Commission (NRC) ${ }^{(6)}$ is a 50-yr internal dose commitment from a $1-y r$ chronic intake, plus a 1 -yr external dose from air submersion, swimming, 
TABLE 3. Nuclides for Which Dose Factors are Currently Available

\begin{tabular}{|c|c|c|c|c|c|}
\hline $3_{H}$ & ${ }^{84} \mathrm{Br}$ & ${ }^{101} \mathrm{TC}$ & $132 \mathrm{I}$ & $147 \mathrm{Pm}$ & ${ }^{232} \mathrm{Th+}$ \\
\hline $10_{\mathrm{Be}}$ & $85_{B r}$ & $103_{R u+d}$ & $133 \mathrm{I}$ & ${ }^{148 m_{P m+d}}$ & ${ }^{234} T h+d$ \\
\hline${ }^{14} \mathrm{C}$ & $83 m_{K r}$ & ${ }^{106} R u+d$ & $134 \mathrm{I}$ & $148 \mathrm{Pm}$ & $231 p$ \\
\hline $13_{N}$ & $85 m_{K r}$ & ${ }^{106} \mathrm{Ru+d}$ & $135 \mathrm{I}+d$ & ${ }^{149} \mathrm{Pm}$ & ${ }^{233} \mathrm{~Pa}$ \\
\hline $18 \mathrm{~F}$ & $85_{\mathrm{Kr}}$ & $105_{R h}$ & $131 \mathrm{~m}_{\mathrm{Xe}}$ & ${ }^{151} \mathrm{Pm}$ & ${ }^{232} u+d$ \\
\hline${ }^{22} \mathrm{Na}$ & $87_{\mathrm{Kr}}$ & $107 \mathrm{Pd}$ & $133 m_{X e}$ & $151 \mathrm{Sm}$ & $233 \mathrm{J+d}$ \\
\hline${ }^{24} \mathrm{Na}$ & $88_{K r}$ & ${ }^{109} \mathrm{Pd}$ & $133 \mathrm{Xe}$ & ${ }^{153} \mathrm{Sm}$ & ${ }^{234} U$ \\
\hline $32 p$ & $89 \mathrm{Kr}$ & $110 m_{A g+d}$ & $135 m_{X e}$ & $152 \mathrm{Eu}$ & $235_{U+d}$ \\
\hline${ }^{33} p$ & ${ }^{86} \mathrm{Rb}$ & ${ }^{111} \mathrm{Ag}$ & $135 \mathrm{xe}$ & ${ }^{154}{ }_{E U}$ & $236 u$ \\
\hline${ }^{39} \mathrm{Ar}$ & ${ }^{87} \mathrm{Rb}$ & $113 m_{C d}$ & $137 \mathrm{Xe}$ & $155_{\mathrm{Eu}}$ & $237_{U}$ \\
\hline${ }^{41} \mathrm{Ar}$ & ${ }^{88} \mathrm{Rb}$ & $115 m_{C d}$ & $138 \mathrm{xe}$ & $156_{E u}$ & $238_{u+d}$ \\
\hline${ }^{41} \mathrm{Ca}$ & ${ }^{89} R b+d$ & ${ }^{123} S n$ & ${ }^{134 m} \mathrm{Cs}$ & ${ }^{160} \mathrm{~Tb}$ & $237 N p+d$ \\
\hline${ }^{46} \mathrm{Sc}$ & ${ }^{89} \mathrm{Sr}+d$ & $125_{S n+d}$ & ${ }^{134} \mathrm{Cs}$ & $166 \mathrm{~m}_{\mathrm{HO}}$ & ${ }^{238} \mathrm{~Np}$ \\
\hline${ }^{51} \mathrm{Cr}$ & $90 \mathrm{sr+d}$ & $126_{S n+d}$ & ${ }^{135} \mathrm{Cs}$ & $181_{W}$ & ${ }^{239} \mathrm{~Np}$ \\
\hline${ }^{54}{ }_{M n}$ & ${ }^{91} \mathrm{Sr+d}$ & ${ }^{124} \mathrm{Sb}$ & ${ }^{136} \mathrm{Cs}$ & $185_{W}$ & $238 \mathrm{Pu}$ \\
\hline${ }^{56}{ }_{\mathrm{Mn}}$ & ${ }^{92} s r+d$ & $125_{S b+d}$ & ${ }^{137} \mathrm{Cs}+\mathrm{d}$ & 187 W & ${ }^{239} \mathrm{Pu}$ \\
\hline${ }^{55} \mathrm{Fe}$ & $90_{Y}$ & ${ }^{126} \mathrm{Sb}$ & ${ }^{138} \mathrm{Cs}$ & $210 p b+d$ & $240 \mathrm{Pu}$ \\
\hline${ }^{59} \mathrm{Fe}$ & $91 m_{Y+d}$ & 127 Sb & ${ }^{139} \mathrm{Cs}+\mathrm{d}$ & $210_{B i+d}$ & $241 \mathrm{Pu}$ \\
\hline${ }^{57} \mathrm{Co}$ & ${ }^{91} Y$ & ${ }^{125 m_{T e}}$ & $139 \mathrm{Ba}$ & $210_{\mathrm{PO}}$ & $242 \mathrm{Pu}$ \\
\hline${ }^{58} \mathrm{Co}$ & $92 y$ & $127 \mathrm{~m}_{\mathrm{Te}+\mathrm{d}}$ & $140 \mathrm{Ba}+\mathrm{d}$ & $222 R n+d$ & $244 \mathrm{Pu}$ \\
\hline${ }^{60} \mathrm{CO}$ & $93 y$ & ${ }^{127} \mathrm{Te}$ & ${ }^{141_{\mathrm{Ba}}}$ & ${ }^{223} \mathrm{Ra}+\mathrm{d}$ & ${ }^{241} \mathrm{Am}$ \\
\hline${ }^{59} \mathrm{Ni}$ & ${ }^{93} \mathrm{Zr+d}$ & $129 \mathrm{~m}_{\mathrm{Te}+\mathrm{d}}$ & ${ }^{142} \mathrm{Ba}$ & ${ }^{224} R a+d$ & $242 m_{A m}$ \\
\hline${ }^{63_{\mathrm{Ni}}}$ & ${ }^{95} \mathrm{Zr+d}$ & ${ }^{129} \mathrm{Te}$ & $140_{\mathrm{La}}$ & ${ }^{225} \mathrm{Ra}+\mathrm{d}$ & ${ }^{243} \mathrm{Am}$ \\
\hline${ }^{65} \mathrm{Ni}$ & $97 \mathrm{Zr+d}$ & $131 \mathrm{~m}_{\mathrm{Te}+\mathrm{d}}$ & $141_{\mathrm{La}}$ & $226_{\mathrm{Ra}+\mathrm{d}}$ & $242 \mathrm{~cm}$ \\
\hline${ }^{64} \mathrm{Cu}$ & $93 m_{N b}$ & $131 \mathrm{Te}+\mathrm{d}$ & ${ }^{142} \mathrm{La}$ & $228 \mathrm{Ra}+d$ & ${ }^{243} \mathrm{~cm}$ \\
\hline${ }^{65} \mathrm{Zn}$ & ${ }^{95} \mathrm{Nb}$ & ${ }^{132} \mathrm{Te}+\mathrm{d}$ & ${ }^{141} \mathrm{Ce}$ & $225 \mathrm{AC}$ & ${ }^{244} \mathrm{Cm}$ \\
\hline $69 m_{\mathrm{Zn}}$ & $97 \mathrm{Nb}$ & $133 m_{T e+d}$ & ${ }^{143} \mathrm{Ce}+\mathrm{d}$ & ${ }^{227} A c+d$ & ${ }^{245} \mathrm{Cm}$ \\
\hline${ }^{69} \mathrm{Zn}$ & ${ }^{93} \mathrm{MO}$ & ${ }^{134} \mathrm{Te}$ & ${ }^{144} \mathrm{Ce}+\mathrm{d}$ & $227_{T h+d}$ & ${ }^{246} \mathrm{Cm}$ \\
\hline${ }^{79} \mathrm{Se}$ & ${ }^{99} \mathrm{Mo}+\mathrm{d}$ & ${ }^{129} \mathrm{I}$ & ${ }^{143} \mathrm{Pr}$ & ${ }^{228} T h+d$ & ${ }^{247} \mathrm{Cm}$ \\
\hline $82_{B r}$ & ${ }^{99} m_{T c}$ & $130 \mathrm{I}$ & ${ }^{144} \mathrm{Pr}$ & ${ }^{229} T h$ & ${ }^{248} \mathrm{C}$ \\
\hline $83_{B r+d}$ & ${ }^{99} \mathrm{TC}$ & $131 \mathrm{I}+\mathrm{d}$ & $147 \mathrm{Nd}$ & ${ }^{230} T h+d$ & 252 \\
\hline
\end{tabular}


contaminated soil, etc. This type of dose calculation is planned for the current study although the first year internal dose will be added since the existing programs generate these doses automatically.

Other more complicated dose commitments can be calculated but the time and expense may not warrant such calculations. For example, the accumulated dose could be calculated for a person living for $50 \mathrm{yr}$ in the vicinity of the nuclear facility, who is not only exposed continuously during the facility's lifetime (30 to $40 \mathrm{yr}$ for a reactor or reprocessing plant) but is also exposed to residual contamination in soil as well as the food grown in that soil after the facility shuts down; thus, a total exposure time of $50 \mathrm{yr}$. This discussion generally applies only to the doses received by a maximally exposed individual in the vicinity of a nuclear facility or the population residing within a reasonable distance $(50 \mathrm{miles}$ or $80 \mathrm{~km})$ of a nuclear facility.

\section{DOSE TO MAN - LIQUID PATHWAYS}

A computer program ARRRG calculates radiation doses to man from liquid effluent releases via the pathways of drinking water, aquatic foods, and aquatic recreation. The mathematical model is described below.

Drinking water

The dose rate from ingestion of water is calculated by

$$
R_{p r}=1119 \sum_{i=1}^{n} \frac{Q_{i} N_{i}}{F} M_{p} U_{p} D_{i p r} \exp \left(-\lambda_{i} t_{p}\right)
$$

where

$R_{p r}$ is dose rate to organ $r$ from all of the nuclides $i$ via pathway $p$

$Q_{i}$ is release rate of nuclide $i(\mathrm{C} / \mathrm{yr})$,

$N_{i}$ is reconcentration factor,

$F$ is flow rate of the liquid effluent $\left(\mathrm{ft}^{3} / \mathrm{sec}\right)$, 
$M_{p}$ is the mixing ratio at the point of exposure (or the point of withdrawal of drinking water or the point of harvest of aquatic food),

$\lambda_{i}$ is the radiological decay constant of nculide $i\left(\mathrm{hr}^{-1}\right)$,

$t_{p}$ is the transit time required for nuclides to reach the point of exposure [for internal dose, $t_{p}$ is the total time elapsed between release of the nuclides and ingestion of food or water (hr)], and

1119 is a constant which converts from $(\mathrm{Ci} / \mathrm{yr}) /\left(\mathrm{ft}^{3} / \mathrm{sec}\right)$ to $\mathrm{pCi} / \mathrm{l}$.

The terms $\frac{Q_{i} N_{i}}{F}$ in Eq. (2) define the concentration of nuclide $i$ in the effluent at the point of discharge. The expression $\frac{Q_{i} N_{j}}{F} M_{p} \exp \left(-\lambda_{i} t_{p}\right)$ yields the concentration at the time that the water is consumed. This latter concentration is the term $C_{\text {ip }}$ in Eq. (1).

Aquatic Foods

Concentrations of radionuclides in aquatic foods are directly related to the concentrations of the nuclides in water. Equilibrium ratios between the two concentrations, called bioaccumulation factors in this report, were taken from References 8 and 9 and are listed in Table 4 . The equation to calculate internal dose rate from consumption of aquatic food is

$$
R_{p r}=1119 \sum_{i=1}^{n} \frac{Q_{i} N_{i}}{F} M_{p} B_{i p} U_{p} D_{i p r} \exp \left(-\lambda_{i} t_{p}\right)
$$

where $B_{i p}$ is the bioaccumulation factor for nuclide $i$ via pathway $p(p C i / k g$ per $\mathrm{pCi} / \ell)$.

Shoreline Deposits

The calculation of sediment load, transport, and concentrations of radionuclides associated with suspended and deposited materials is a complex problem. One approach to this problem was used in the Year 2000 study. For the program ARRRG, a simplified scheme for obtaining an order of magnitude estimate of the concentration of shoreline sediments was developed. The concentration of nuclide $i$ in the sediment can be estimated from

$$
S_{i}=\frac{K A_{i}}{\lambda_{i}}\left[1-\exp \left(-\lambda_{i} t_{s}\right)\right]
$$


TABLE 4. Bioaccumulation Factors ( $p C i / k g$ per $p C i / l$ )

\begin{tabular}{|c|c|c|c|c|c|c|c|c|}
\hline \multirow[b]{2}{*}{ Element } & \multicolumn{4}{|c|}{ Salt Water Factors } & \multicolumn{4}{|c|}{ Fresh Water Factors } \\
\hline & Fish & Crus. & Mol1. & Algae & Fish & Crus. & Moll. & Algae \\
\hline $\mathrm{H}$ & 1 & 1 & 1 & 1 & 0.9 & 0.9 & 0.9 & 0.9 \\
\hline Be & 1,000 & 10,000 & 10,000 & 10,000 & & 10 & 10 & 20 \\
\hline${ }_{N}^{C}(a)$ & & & & & 4,600 & 9,100 & 9,100 & 4,600 \\
\hline $\mathrm{N}^{2}(\mathrm{a})$ & 0 & 0 & 0 & 0 & & & & \\
\hline $\mathrm{F}$ & 4 & 4 & 4 & 1 & 10 & 100 & 100 & 2 \\
\hline $\mathrm{Na}$ & 1 & 1 & 1 & 1 & 100 & 200 & 200 & 500 \\
\hline$P$ & 10,000 & 10,000 & 10,000 & 100,000 & 100,000 & 20,000 & 20,000 & 500,000 \\
\hline Ar & 1 & 1 & 1 & 1 & 1 & & 1 & \\
\hline $\mathrm{Ca}$ & 10 & 10 & 10 & 1 & 40 & 330 & 330 & 130 \\
\hline Sc & 100 & 300 & 300 & 1,000 & 2 & 1,000 & 1,000 & 10,000 \\
\hline $\mathrm{Cr}$ & 100 & 1,000 & 1,000 & 1,000 & 20 & 2,000 & 2,000 & 4,000 \\
\hline$M n$ & 3,000 & 10,000 & 50,000 & 10,000 & 400 & 90,000 & 90,000 & 10,000 \\
\hline $\mathrm{Fe}$ & 1,000 & 4,000 & 20,000 & 6,000 & 100 & 3,200 & 3,200 & 1,000 \\
\hline Co & 100 & 10,000 & 300 & 100 & 50 & 200 & 200 & 200 \\
\hline $\mathrm{Ni}$ & 500 & 100 & 100 & 100 & 100 & 100 & 100 & 50 \\
\hline $\mathrm{Cu}$ & 1,000 & 5,000 & 5,000 & 1,000 & 50 & 400 & 400 & 2,000 \\
\hline Zn & 5,000 & 5,000 & 50,000 & 1,000 & 2,000 & 10,000 & 10,000 & 20,000 \\
\hline Se & 10 & 10 & 10 & 100 & 170 & 170 & 170 & 1,000 \\
\hline $\mathrm{Br}$ & 3 & 10 & 10 & 100 & 420 & 330 & 330 & 50 \\
\hline $\mathrm{kr}$ & 1 & 1 & 1 & 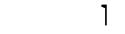 & 1 & 1 & 1 & 1 \\
\hline $\mathrm{Rb}$ & 30 & 50 & 10 & 10 & 2,000 & 1,000 & 1,000 & 1,000 \\
\hline Sr & 1 & 1 & 1 & 20 & 30 & 100 & 100 & 500 \\
\hline Y & 30 & 100 & 100 & 300 & 25 & 1,000 & 1,000 & 5,000 \\
\hline $\mathrm{Zr}$ & 30 & 100 & 100 & 1,000 & 3 & 6 & 6 & 1,000 \\
\hline $\mathrm{Nb}$ & 100 & 200 & 200 & 100 & 30,000 & 100 & 100 & 800 \\
\hline Mo & 10 & 100 & 100 & 100 & 10 & 10 & 10 & 1,000 \\
\hline Tc & 10 & 100 & 100 & 1,000 & 15 & 5 & 5 & 40 \\
\hline Ru & 3 & 100 & 100 & 1,000 & 10 & 300 & 300 & 2,000 \\
\hline $\mathrm{Rh}$ & 10 & 100 & 100 & 100 & 10 & 300 & 300 & 200 \\
\hline Pd & 10 & 100 & 100 & 100 & 10 & 300 & 300 & 200 \\
\hline $\mathrm{Ag}$ & 1,000 & 5,000 & 5,000 & 1,000 & 2 & 770 & 770 & 200 \\
\hline$C d$ & 100 & 3,000 & 10,000 & 10,000 & 200 & 2,000 & 2,000 & 1,000 \\
\hline Sn & 3 & 3 & 3 & 10 & 3,000 & 1,000 & 1,000 & 100 \\
\hline Sb & 1,000 & 1,000 & 1,000 & 10,000 & 1 & 10 & 10 & 1,500 \\
\hline $\mathrm{Te}$ & 10 & 10 & 100 & 1,000 & 400 & 75 & 75 & 100 \\
\hline I & 20 & 100 & 100 & 10,000 & 15 & 5 & 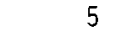 & 40 \\
\hline $\mathrm{Xe}_{\mathrm{e}}$ & 1 & 1 & 1 & 1 & 1 & 1 & 1 & 1 \\
\hline Cs & 30 & 50 & 10 & 10 & 2,000 & 100 & 100 & 500 \\
\hline $\mathrm{Ba}$ & 3 & 3 & 3 & 100 & 4 & 200 & 200 & 500 \\
\hline La & 30 & 100 & 100 & 30 & 25 & 1,000 & 1,000 & 5,000 \\
\hline $\mathrm{Ce}$ & 30 & 100 & 100 & 36 & 1 & & & 4,000 \\
\hline $\mathrm{Pr}$ & 100 & 1,000 & 1,000 & 1,000 & 25 & 1,000 & 1,0 & 5,000 \\
\hline Nd & 100 & 1,000 & & 1,0 & 25 & 1,000 & 1,000 & 000 \\
\hline$P m$ & 100 & & & & 25 & 1 , & 1, & 000 \\
\hline Sm & 100 & 1, & & 1, & 25 & 1, & 1, & 100 \\
\hline Eu & 100 & & & & 25 & 1,000 & 1,0 & 000 \\
\hline T & 10 & & & & 25 & 1,000 & & 000 \\
\hline Ho & 100 & 0 & 00 & 1, & 25 & 1,000 & 1,000 & 000 \\
\hline W & 10 & 10 & 10 & 10 & 1,200 & 10 & 10 & 1,200 \\
\hline PD & 300 & 1,000 & & & 100 & 100 & 100 & 200 \\
\hline$B i$ & 15 & & & 10 & 15 & 10 & 10 & 1,500 \\
\hline Bo & 300 & 5,000 & 5,000 & 2,000 & 500 & 20,000 & 20,000 & 2,000 \\
\hline $\mathrm{Rn}$ & 1 & & & & 57 & & & \\
\hline Ra & 50 & 100 & 100 & 100 & 50 & 250 & 250 & 2,500 \\
\hline$A C$ & 25 & 1,000 & 1,000 & 5,000 & 25 & 1,000 & 1,000 & 5,000 \\
\hline Th &, 000 & 2,000 & 2,000 & 3,000 & 30 & 500 & 500 & 1,500 \\
\hline $\mathrm{Pa}$ & 10 & 10 & 10 & 6 & 11 & 110 & 110 & 1,100 \\
\hline U & 10 & 10 & 10 & 67 & 2 & 60 & 60 & \\
\hline$N p$ & 10 & 10 & 10 & 6 & 10 & 400 & 400 & 300 \\
\hline $\mathrm{Pu}$ & 3 & 200 & 200 & 1,000 & 3 & 100 & 100 & 350 \\
\hline Am & 25 & 1,000 & 1,000 & 5,000 & 25 & 1,000 & 1,000 & 5,000 \\
\hline $\mathrm{Cm}$ & 25 & 1,000 & 1,000 & 5,000 & 25 & 1,000 & 1,000 & 5,000 \\
\hline Cf & 25 & 1,000 & 1,000 & 5,000 & 25 & 1,000 & 1,000 & 5,000 \\
\hline
\end{tabular}

(a) The values for nitrogen (0) were selected because $N-13$ has a half life of only $9.6 \mathrm{~min}$. 
where

$S_{i}$ is the concentration of nuclide $i$ in sediment ( $\left.\mathrm{pC} i / \mathrm{kg}\right)$,

$K$ is the assumed constant in units of $l / k g-d a y$,

$A_{i}$ is the concentration of the nuclide $i$ in the water adjacent to sediment $(p C i / \ell)$, and

$t_{s}$ is the total time the sediment is exposed to the contaminated water, nominally taken to be the operating lifetime of the facility (hr).

In the original evaluation of the equation, $\lambda_{i}$ was chosen to be the radiological decay constant, although the true value should include an unknown "environmental" removal constant. If the presence of a radionuclide in water and sediment is controlled primarily by radioactive equilibrium with its parent nuclide, then the water concentration and half-life of the parent should be used in the equation.

The relationship was tested and the value of $K$ derived from radionuclide concentrations measured in water and sediment samples collected over a period of several years in the Columbia River between Richland, Washington and the river mouth and in Tillamook Bay, Oregon, $75 \mathrm{~km}$ (47 miles) south of the river mouth. $(10,11)$ since the primary use of the equation is to facilitate estimates of the exposure rate from gamma emitters $1 \mathrm{~m}$ above the sediment, an effective surface contamination was devised. This surface contamination level was taken to be all of the nuclides contained within the top $2.5 \mathrm{~cm}$ (1 in.) of sediment. (a) The dose contribution from the radionuclides below $2.5 \mathrm{~cm}$ in depth was ignored. The resulting equation is

$$
S_{i}^{\prime}=100 T_{i} A_{i} W\left[1-\exp \left(-\lambda_{i} t_{s}\right)\right]
$$

where

$s_{i}^{\prime}$ is "effective" surface contamination $\left(\mathrm{pci} / \mathrm{m}^{2}\right)$,

$T_{i}$ is radiological half-life of nuclide $i$ (days), and

$W$ is shore width factor (unitless).

Shore width factors were derived from data given in Figure 3.1(5) of Reference 12 and are summarized in Table 5 .

(a) Calculated by multiplying the concentration $(\mathrm{pCi} / \mathrm{kg})$ by a mass thickness $\left(40 \mathrm{~kg} / \mathrm{m}^{2}\right)$. 
TABLE 5. Shore width Factors Used in Eq. (5) and (6)

\begin{tabular}{lc}
\multicolumn{1}{c}{ Exposure Situation } & Shore Width Factor, $W$ \\
\hline Discharge canal bank & 0.1 \\
River shoreline & 0.2 \\
Lake shore & 0.3 \\
Nominal ocean site & 0.5 \\
Tidal basin & 1.0 \\
Organisms on surface or & 2.0 \\
in burrow(a) &
\end{tabular}
(a) Since the radionuclide concentration normally decreases with depth in the mud, the dose to a buried organism is probably no higher than that to one lying on the mud surface.

The combination of Eq. (2) and (5) yields Eq. (6) which calculates the radiation dose rate from exposure to shoreline sediments.

$$
\begin{aligned}
R_{p r} & =\sum_{i=1}^{n} S_{i}^{\prime} U_{p} D_{i p r}=100 \sum_{i=1}^{n} T_{i} A_{j} w U_{p} D_{i p r}\left[1-\exp \left(-\lambda_{i} t_{s}\right)\right] \\
& =111,900 \sum_{i=1}^{n} T_{i} \frac{Q_{i} N_{i}}{F} M_{p} \exp \left(-\lambda_{i} t_{p}\right) W U_{p} D_{i p r}\left[1-\exp \left(-\lambda_{i} t_{s}\right)\right]
\end{aligned}
$$

Swimming and Boating

The equation for external dose rate to the skin and total body from swimming (water immersion) or boating (water surface) is

$$
R_{p r}=1119 \sum_{i=1}^{n} \frac{Q_{i} N_{i}}{F K_{p}} M_{p} U_{p} D_{i p r} \exp \left(-\lambda_{i} t_{p}\right)
$$

where $k_{p}$ is a geometry correction factor equal to 1 for swimming and 2 for boating. 
DOSE TO MAN - GASEOUS PATHWAYS

The computer program GRONK is used to calculate radiation doses to man from radionuclides released with gaseous effluents.

\section{Air Submersion}

The formulas used to calculate dose rate from air submersion are Eq. (8) and (9). (13)

$$
R_{p r}(x, \theta, d)=\sum_{i=1}^{n} \bar{x}_{i} u_{p} D_{i p r}
$$

where

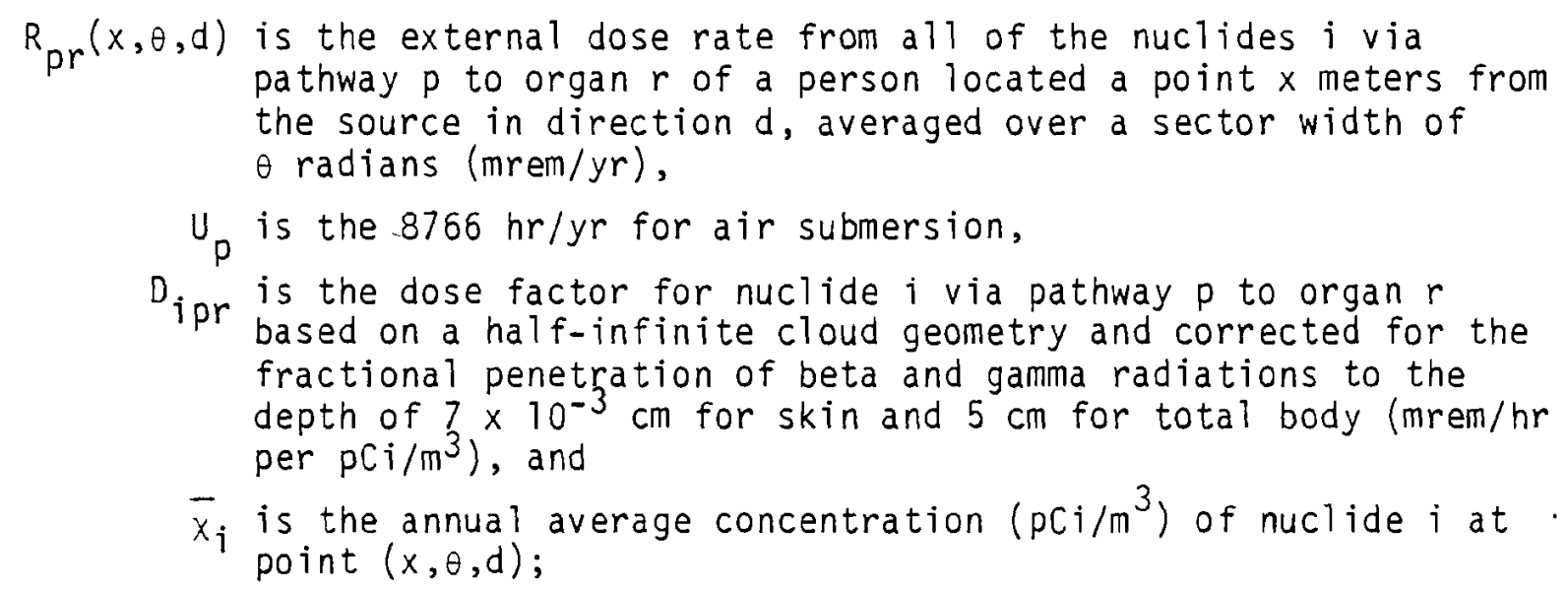

and

$$
\bar{x}_{i}=\sum_{j=1}^{j}\left(\frac{2}{\pi}\right)^{1 / 2} \frac{\left(0.01 f_{j}\right) 10^{12} Q_{i}^{\prime}}{\left(\sigma_{z}\right)_{j} \bar{u}_{j} \theta x}\left[\exp \left(-\frac{h^{2}}{2\left(\sigma_{z}\right)^{2}}\right)\right]\left[\exp \left(-\frac{\lambda_{j} x}{\bar{u}_{j}}\right)\right]
$$

where

$f_{j}$ is percent of time wind blows in direction d under meterological $10^{12}$ is picocuries per curie,

$Q_{i}^{\prime}$ is relsease rate of nuclide $i$ ( $\left.\mathrm{C} / \mathrm{sec}\right)$, 
$\theta$ is sector width $=2 \pi / n$ radians, where the number of sectors $n$ is normally 16 ,

$x$ is downwind distance $(m)$,

$\bar{u}_{j}$ is average wind speed for meteorological condition $j(\mathrm{~m} / \mathrm{sec})$,

$x$ is travel time of released material to point $(x, \theta, d)$ under metero-

$\bar{u}_{j}$ logical condition $j$ (sec),

$\lambda_{i}$ is radiological decay constant for nuclide $i\left(\mathrm{sec}^{-1}\right)$,

$h$ is height of effluent release $(m)$,

$\left(\sigma_{z}\right)_{j}$ is standard deviation of vertical dispersion under meterological

$J$ is number of meteorological conditions ("stability classes").

The standard deviation of vertical dispersion may be derived for the Hanford (Fuquay-Simpson) four-stability-class method from equations given in Reference 13 (pp. 141 and 392), or from tables of $\sigma_{z}$ versus $x$ by Pasquill stability category, Reference 13 (p. 409). Both the Hanford and the Pasquill formats are programmed into GRONK since raw meterology data may be given in either format, depending upon the particular system employed at the nuclear facility.

Equation (8) yields the yearly external dose to a person located at point $(x, \theta, d)$. The population dose in man-rem/yr is determined by multiplying this dose by the population located within the sector of the annulus of concern. Values of the dose at the point $(x, \theta, d)$ are assumed to apply to all individuals located in that sector.

Doses from Inhalation

The equation used to calculate inhalation dose rate is given by:

$$
R_{i p r}(x, \theta, d)=\sum_{i=1}^{n} 3.169 \times 10^{4} D_{i p r} \bar{x}_{i} u_{p}
$$


where

$$
\begin{aligned}
& R_{i p r}(x, \theta, d) \text { is internal dose rate from } n \text { nuclides } i \text { via pathway } p \text { to } \\
& \text { organ } r \text { of a person located at a point } x \text { meters from the } \\
& \text { source in a direction } d \text {, averaged over a sector width of } \\
& \\
& \theta \text { radians (mrem/yr), }
\end{aligned}
$$

$3.169 \times 10^{4}$ is dimensional conversion constant ( $\mathrm{pCi} / \mathrm{sec}$ per $\mathrm{Ci} / \mathrm{yr}$ ),

$$
\begin{aligned}
& \text { Dipr is dose factor for organ } r \text { from inhalation of nuclide } i \\
& \text { (mrem/yr per } p(i / y r) \text {, and }
\end{aligned}
$$$$
U_{p} \text { is ventilation rate }\left(\mathrm{m}^{3} / \mathrm{yr}\right) \text {. }
$$

Equation (10) yields the yearly internal radiation dose to an individual located at point $(x, \theta, d)$. The population dose in man-rem/yr is determined by multiplying the dose to an individual by the population located within the sector of the annulus of interest. Values of the dose at the point $(x, \theta, d)$ are assumed to apply to all individuals located in that sector. The total population dose in a region can be obtained by summing the population doses within al1 of the sectors of the region.

\section{DOSE TO MAN - FOODS}

The computer program FOOD is designed to calculate radiation doses to man from ingestion of foods, such as produce, milk, eggs and meat contaminated by radionuclides. These radionuclides may be deposited on vegetation and on the ground by water used for irrigation or directly from the air. A total of 14 food categories can be selected with corresponding consumption rates, growing periods and irrigation rates or atmospheric deposition assigned by the user. The program can presently calculate doses to the total body and to six internal organs from 187 radionuclides; dose summaries are displayed at the local terminal. Additional details on the percent of contribution to dose by radionuclide and by food type are available from an auxiliary high-speed printer. This latter output also includes estimated radionuclide concentrations in soil, plants and animal products. The program is designed to be compatible with files of releases and dose factors which are used by the program ARRRG. 
The mathematical model presented for estimating the transfer of radionuclides (except for ${ }^{3} H$ and ${ }^{14} \mathrm{C}$ ) from irrigation water or from air to plants through both leaves and soil to food products was derived by Soldat (HEDLTME-71-168) ${ }^{(6)}$ for a study of the potential doses to people from a nuclear power complex in the year 2000.

Deposition on Food Products

Radionuclide contamination of foods may be either via deposition with water used for sprinkler irrigation or deposition of airborne radionuclides. In the absence of specific data, sprinkler rather than surface irrigation was assumed for this study, because the aerial spray produced by the sprinkler leads to foliar deposition, which results in higher radionuclide concentrations in the plants (and animals consuming them) than would irrigation via furrows or drip.

Deposition by Irrigation Water

The deposition rate $d_{i}$ from irrigation water is defined by the relation

$$
d_{i}=C_{i w} I \text { (water deposition) }
$$

where

$d_{j}$ represents deposition rate or flux $\left(p C i \cdot m^{-2} \cdot d^{-1}\right)$ of radionuclide $i$, $C_{i w}$ represents concentration of radionuclide $i$ in water used for irrigation $(p C i / \ell)$, and

I represents irrigation rate $\left(2 \cdot \mathrm{m}^{-2} \cdot \mathrm{d}^{-1}\right)$; amount of water sprinkled on unit area of field in 1 day.

Deposition Directly from Air

The deposition rate onto the foliage from airborne radionuclides is:

$$
d_{i}=86,400 \bar{x}_{i} V_{d i} \text { (air deposition) }
$$

where

86,400 is dimensional conversion factor (sec/d),

$\bar{x}_{i}$ is annual average air concentration $\left(\mathrm{pCi} / \mathrm{m}^{3}\right)$ of radionuclide $i$, and $v_{d i}$ is deposition "velocity" of radionuclide $i(\mathrm{~m} / \mathrm{sec})$. 


\section{Concentration in Vegetation}

The concentration of radioactive material in vegetation resulting from deposition onto the plant foliage and uptake from the soil of prior depositions is given by:

$c_{i v}=d_{i}\left[\frac{r T_{V}\left[1-\exp \left(-\lambda_{E i} t_{e}\right)\right]}{Y_{V} \lambda_{E i}}+\frac{B_{i v}\left[1-\exp \left(-\lambda_{i} t_{b}\right)\right]}{P \lambda_{i}}\right] \exp \left(-\lambda_{i} t_{h}\right)$

where

$c_{i v}$ is concentration of radionuclide $i$ in edible portion of plant $v$

$r$ is fraction of deposition retained on plant (dimensionless), taken to be 0.25 ,

$T_{v}$ is factor for the translocation of externally deposited radionuclide to edible parts of plants (dimensionless). For simplicity it is taken to be independent of radionuclide and set to 1 for leafy vegetables and fresh forage, and 0.1 for all other produce, including grain. (Reference 6 lists values of this parameter which vary with nuclide.),

$\lambda_{i}$ is radiological decay constant for radionuclide $i\left(d^{-1}\right)$,

$\lambda_{E i}$ is effective removal constant of radionuclide $i$ from plant $\left(d^{-1}\right)$ $\lambda_{E i}=\lambda_{i}+\lambda_{w}$,

$\lambda_{W}$ is weathering removal constant $=0.693 / 14\left(d^{-1}\right)$,

$t_{e}$ is time of above ground exposure of crop to contamination during growing season (d),

$Y_{v}$ is plant yield [ $\mathrm{kg}$ (wet weight)/ $\left./ \mathrm{m}^{2}\right]$,

$B_{i v}$ is concentration factor for plant uptake of nuclide $i$ from soil $[\mathrm{pCi} / \mathrm{kg}$ (wet weight) per $\mathrm{pCi} / \mathrm{kg}$ (dry soil)],

$t_{b}$ is time for buildup of radionuclide in soil (d) (In this analysis $t_{b}$ was $1.10 \times 10^{4}$ days, i.e., the $30-y r$ operating life time of the nuclear facility.),

$P$ is soil "surface density" $\left[\mathrm{kg}(\operatorname{dry}\right.$ soil $\left.) / \mathrm{m}^{2}\right]$. Assuming a uniform mixing of all radionuclides in a plowlayer of $15-\mathrm{cm}$ depth, $P$ has a value of $224 \mathrm{~kg} / \mathrm{m}^{2},(6)$ and

$t_{h}$ is holdup time (d) (time between harvest and consumption of the food. 
The first term inside the brackets of Eq. (13) relates to the concentration derived from direct foliar deposition during the growing season, whereas the second term relates to uptake from soil and reflects the deposition throughout the time from start of deposition until harvest of the plant.

For a cow grazing on fresh forage, $t_{e}$ in Eq. (13) is set equal to 30 days, the typical time for a cow to return to a particular portion of a grazing site.

\section{Concentration in Animal Products}

The radionuclide concentration in an animal product such as meat, milk or eggs is dependent on the amount of contaminated feed or forage eaten by the animal and its intake of contaminated water. The following equation describes this calculation. ${ }^{(6)}$

$$
c_{i a}=s_{i a}\left[c_{i F} Q_{F}+c_{i a w} Q_{a w}\right]
$$

where

$C_{i a}$ is the concentration in animal product $(p C i / 2)$ or $(p C i / k g)$,

$S_{i a}$ is the transfer coefficient of radionuclide $i$ from daily intake of animal to edible portion of animal product [ $\mathrm{pCi} / \mathrm{l}(\mathrm{mi} 1 \mathrm{k}) \mathrm{per}$ - $\mathrm{pCi} / \mathrm{d}]$ or $[\mathrm{pCi} / \mathrm{kg}$ (animal product) per $\mathrm{pCi} / \mathrm{d}]$,

$C_{i F}$ is the concentration of nuclide $i$ in feed or forage $(\mathrm{pCi} / \mathrm{kg}$ ) calculated from Eq. (2) above,

$Q_{F}$ is the consumption rate of contaminated feed or forage by animal $(\mathrm{kg} / \mathrm{d})$,

$C_{i a w}$ is the concentration of nuclide $i$ in water consumed by animals ( $p C i / l)$; assumed to be equal to $C_{i w}$, and

$Q_{a w}$ is the consumption rate of contaminated water by animal $(\ell / d)$.

The second set of terms in the brackets in Eq. (14) is omitted if the animal does not drink contaminated water. Animal consumption rates normally assumed are given in Table 6 .

Plant concentration factors and animal product transfer coefficients for the elements considered in the study are given in Table 7. Plant concentration factors were taken from UCRL-50163, pt. IV ${ }^{(14)}$ and supplemented with 
TABLE 6. Consumption Rates (1) of Feed
and Water by Farm Animals

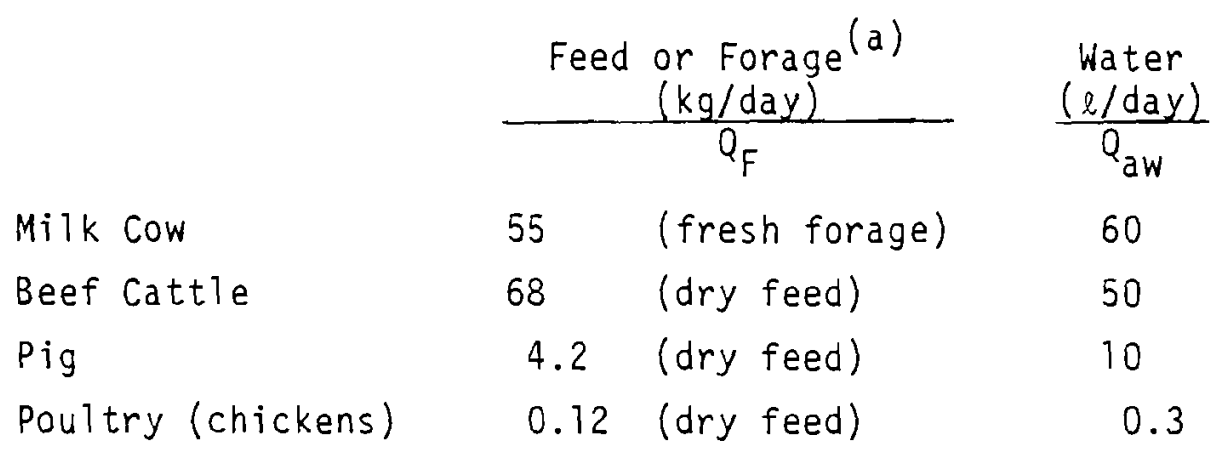

(a) Equivalent fresh weight used to ensure proper calculation of radionuclide intake by animal.

radionuclide data as explained in Reference 6 . The 1iterature yielded coefficients of transfer from feed to animal products for a 1 imited number of radionuclides. For those radionuclides lacking data, comparisons were made with the behavior of chemically similar elements in man (7) and animals. In some instances, those identified with an asterisk in Table 7 , the value was set to $9.9 \times 10^{-4}$. The most complete listing of transfer coefficients to be found is that for milk in Reference 14. The milk transfer coefficients given in this reference were intended to be maximum or "worst case" values. The authors imply, by reference to ${ }^{131} \mathrm{I}$, that average values would be about one-half of their listed values. As a result, the milk transfer values in Table 7 for elements lacking specific radionuclide data are one-half of those found in Reference 14.

Some experimental data are available on the transfer of several radionuclides for chicken, eggs and meat. $(15,16)$ Some of these literature sources were referenced in HERMES. (5) Unfortunately very little data are currently available on the transfer of radionuclides to beef and pork. Uncontrolled studies have been performed on the principal constituents of fallout ${ }^{90} \mathrm{Sr}$, ${ }^{131} \mathrm{I}$ and ${ }^{137} \mathrm{CS}^{(6)}$, and the EPA National Environmental Research Center at Las Vegas has an ongoing study of radionuclides in cattle and milk, which we hope will continue to generate usable data for our model. 


\section{TABLE 7. Plant Concentration Factors and Animal Product Transfer Coefficients}

\begin{tabular}{|c|c|c|c|c|c|c|}
\hline Ément & $\begin{array}{c}\text { Plant/Soil } \\
\text { (Dimensioniess) }\end{array}$ & $\begin{array}{l}\text { Egg/Feed } \\
\text { Lday/kgl }\end{array}$ & $\begin{array}{l}M i l k / G r a s s \\
(\text { day/k) } \\
\end{array}$ & $\begin{array}{r}\text { Beef/Feed } \\
(d a y / k g) \\
\end{array}$ & $\begin{array}{r}\text { Pork/Feed } \\
(\mathrm{day} / \mathrm{kg}) \\
\end{array}$ & $\begin{array}{c}\text { Poultry/Feed } \\
(\text { day/kg) }\end{array}$ \\
\hline & $B_{i v}$ & $-\cdots$ & $-\cdots$ & $-S_{i a}$ & $\cdots-\cdots$ & \\
\hline $8 \mathrm{C}$ & $4.7 t-04$ & 2. OF-02 & $2.0,-05$ & $3.05-04$ & $1.0 E-02$ & $4.05-01$ \\
\hline$\|$ & $7.62+00$ & $0.9 E-04(a)$ & $1.71-02$ & $9.9 \mathrm{~L}-0.4$ & $5.25-04$ & $9.9 E-04$ \\
\hline $\mathrm{F}$ & $2 . C \cdot \bar{F}-0 ?$ & $9 . J E-04$ & $7.05-03$ & ?.ME-C? & $9.07-02$ & $9.9 \pi-04$ \\
\hline lia & $5.0 z-02$ & 2. CE-GT & \&.AE-02 & $5.05-02$ & $1.0[-0 !$ & $1.0 E-02$ \\
\hline$p$ & $5.0: 01$ & i. $05+01$ & 1. $2 \mathrm{E}-02$ & $5.0 E-02$ & $5.4 E-01$ & $1.95:-01$ \\
\hline $\mathrm{Ca}$ & $4.0 \varepsilon-02$ & $1.02+00$ & $8.0[-03$ & $3.35-03$ & $3.3 E-03$ & $3.3 E-03$ \\
\hline Sc & $1.1 E-03$ & $9,9 E-04$ & $2.5 \div-06$ & $E .0 E-03$ & i. $0 E-02$ & 4. OE -03 \\
\hline $\mathrm{Cr}$ & $2.5 \bar{E}-04$ & $9.9 E-04$ & $1.15-03$ & $9.9 E-04$ & $9.9 E-04$ & $9.9 E-04$ \\
\hline Mn & $3.05-02$ & $1.0 E-01$ & 1. $0 E-04$ & $5.0 E-\hat{0} 3$ & 2. $O E-02$ & I. IE-0I \\
\hline $\mathrm{Fe}$ & $4.0 E-04$ & $1.0 E-01$ & $6.0 E-04$ & $2.0 E-02$ & $5.0 E-03$ & $1.0 E-03$ \\
\hline $\mathrm{Co}$ & $9.4 \mathrm{E}-03$ & $1.0 E-01$ & $5.0 E-04$ & $1.0 E-103$ & $5.0 E-03$ & $1.0 E-03$ \\
\hline $\mathrm{Ni}$ & $1.9 E-02$ & $1,0 \mathrm{E}-01$ & $3.4 E-03$ & 1.OE-03 & 5. OE-03 & $1.0 E-03$ \\
\hline $\mathrm{Cu}$ & 1. $3 E-01$ & $2.0 E-01$ & $7.0 E-03$ & 1. OE-02 & $1.5 E-02$ & $2.0[-03$ \\
\hline $2 n$ & 4. $C E-01$ & $4.0 E-03$ & $6.05-03$ & $5.0 E-192$ & $1.4 E-01$ & 2. $C E-03$ \\
\hline Se & $1.3 E+00$ & $2.1 E+00$ & $2.3 E-02$ & $1.0 F_{-}+100$ & $4.5 E-01$ & $3.7 E-01$ \\
\hline $\mathrm{Br}$ & $7.6 E-01$ & $1.52+00$ & $2.5 E-02$ & 2. $0 E-02$ & $9.0 E-02$ & $4.0 E-03$ \\
\hline Rb & $1.3 E-01$ & $3.0 E=00$ & 1.OE-0? & $1.5 E-01$ & $2.0 E-01$ & $2.0 E+00$ \\
\hline $\mathrm{Sr}$ & $2.0 E-01$ & $4.0 E-01$ & 1. $5 E-03$ & $3.0 E-04$ & $7.3 E-03$ & $9.0 E-04$ \\
\hline$y$ & $2.5 E-03$ & 5. OE-C. & $5.05-06$ & $5.0 E-03$ & $5.0 E-03$ & $5.0 E-04$ \\
\hline $\mathrm{Zr}$ & $1.7 E-04$ & 1. $2 E-03$ & $2.5 E-06$ & 5. OE-04 & $1.0 E-03$ & $1.0 \mathrm{E}-\mathrm{O} 4$ \\
\hline Nb & $9.4 E-03$ & $1.2 E-03$ & $1.2 E-03$ & $5.0 E-04$ & $1.0 E-03$ & $1 . \hat{V E}-04$ \\
\hline Mo & 1. $3 E-01$ & $4.0 E-01$ & $4.0 E-03$ & $1.0 E-02$ & $2.0 E-02$ & $2.0 E-03$ \\
\hline$T c$ & $2.5 E-01$ & $9.9 E-04$ & $1.2 E-02$ & $9.9 E-04$ & $9.95-04$ & $9.3 E-04$ \\
\hline Ru & $1.0 E-02$ & $4.0 E-03$ & $5.05-07$ & $1.0 E-03$ & $5.0[-0\}$ & $3.0 E-04$ \\
\hline Rh & 1. $3 E+0]$ & $4.0 E-03$ & $5.0 E-03$ & $1.0 \mathrm{E}-03$ & $5.05-03$ & $3.0 E-04$ \\
\hline $\mathrm{Pd}$ & $5.0 E+00$ & $4.0 E-03$ & $5.0 E-03$ & $1.0 \mathrm{E}-03$ & $5.0 E-03$ & $3.0 E-C 4$ \\
\hline $\mathrm{Ag}$ & $1.5 E-01$ & $9.9 E=04$ & $2.5 E-02$ & $9.9 E-04$ & $9.9 E-04$ & $9.9 E-04$ \\
\hline $\mathrm{Cd}$ & $3.0 E-01$ & $9.95-04$ & $6.25-05$ & 1. $6 \mathrm{E}-\mathrm{O} 2$ & $1.6 E-02$ & 1. $.6 \mathrm{E}-02$ \\
\hline Sn & $2.5 E-03$ & $9.9 E-04$ & $1.3 E-03$ & $9.9 \mathrm{E}-04$ & $9.9 E-04$ & $9.9 E-04$ \\
\hline Sb & $1.1 \mathrm{E}-02$ & $7.0 E-02$ & $7.5 E-04$ & $3.0 E-D 3$ & $7.0 E-03$ & $6.0 E-03$ \\
\hline Te & 1. $3 E+00$ & $4.0 \mathrm{E}-01$ & $5.0 E-04$ & $5.0 \mathrm{E}-02$ & $1.0 E-02$ & $1.0 \mathrm{E}-02$ \\
\hline 1 & $2.0 E-02$ & $1.6 \mathrm{E}+00$ & $1.0 E-02$ & $2.0 \mathrm{E}-02$ & $9.0 E-02$ & $4.0 E-03$ \\
\hline Cs & 2. CE-O3 & $6 . O E-0 ?$ & $5.0 E-03$ & $3.0 E-02$ & $2.6 E-01$ & $4.5 E+00$ \\
\hline $\mathrm{Ba}$ & $5.0 E-03$ & $4.0 E-01$ & $4.0 E-04$ & $5.0 E-04$ & $1.0 E-02$ & $5.0 E-04$ \\
\hline La & $2.5 \mathrm{E}-03$ & $2.0 E-03$ & $2.5 \tilde{c}-06$ & 5. OE-O3 & $5.0 E-03$ & $4.0 E-03$ \\
\hline $\mathrm{Ce}$ & $5.0 E-04$ & $3.0 E-03$ & $1.0 E-05$ & $1.0 E-03$ & $5.0 E-03$ & $6.0 E-04$ \\
\hline $\mathrm{Pr}$ & $2.5 \mathrm{E}-03$ & 4. OE-03 & $2.5 E-05$ & $5.0 E-03$ & $5.0 E-03$ & $1.05-03$ \\
\hline $\mathrm{Nd}$ & $2.4 E-03$ & $2.0 E-04$ & $2.5 E-06$ & $5.0 \mathrm{E}-03$ & $5.05-03$ & $4.0 E-03$ \\
\hline $\mathrm{Pm}$ & $2.5 E-03$ & $7.0 E-03$ & $2.5 \tilde{\varepsilon}-06$ & $5.0 E-03$ & $5.0 E-03$ & $1.0 E-04$ \\
\hline $5 m$ & $2.5 E-03$ & $7.0 \mathrm{E}-03$ & $2.5 E-05$ & $5.0 E-03$ & 5.OE-03 & 4.OE-O3 \\
\hline$E_{U}$ & $2.5 \mathrm{E}-03$ & $7.0 E-03$ & $2.5 E-06$ & $5.0 \mathrm{E}-03$ & $5.0 E-03$ & $4.0 E-03$ \\
\hline Tb & $2.6 E-03$ & $7.0 \mathrm{E}-03$ & $2.5 E-06$ & $5.0 E-03$ & $5.0 E-03$ & 4. $. \mathrm{GE}-03$ \\
\hline Ho & $2.6 E-03$ & $7.0 E-03$ & $2.5 E-C 6$ & $5.0 E-03$ & $5.0 E-03$ & $4.0 E-03$ \\
\hline$W$ & $1.8 E-02$ & $9.9 E-04$ & $2.5 E-04$ & $9.9 E-04$ & $9.9 E-04$ & $9.9 E-04$ \\
\hline $\mathrm{Pb}$ & $6.8 E-02$ & $9.9 E-04$ & $1.0 E-05$ & $9.9 E-04$ & $9.9 E-04$ & $9.9 E-04$ \\
\hline $\mathrm{Bi}$ & $1.5 E-01$ & $9.9 \mathrm{E}-04$ & $2.5 \vec{E}-04$ & $9.9 E-04$ & $9.9 E-04$ & $0.9 E-04$ \\
\hline Po & $9.0 E-03$ & $9.9 E-04$ & $1.2 E-04$ & $9.3 E-04$ & $9.9 E-04$ & $9.9 E-04$ \\
\hline$R a$ & $1.4 E-03$ & $2.0 \bar{E}-05$ & $2.0 \tilde{\varepsilon}-04$ & & $9.9 E-04$ & $9.9 F-04$ \\
\hline$A C$ & $2.5 E-03$ & $2.0 E-03$ & $2.5 \bar{E}-06$ & $5.05-03$ & $1.0 E-02$ & 4. CE-03 \\
\hline Th & $4.2 E-03$ & $2.0 E-03$ & 2. $5 E-06$ & $5.0 E-03$ & $1.0 E-02$ & 4. OE-03 \\
\hline $\mathrm{Pa}$ & $2.5 E-03$ & $2.0 \mathrm{E}-03$ & $2.5 E-0 E$ & $5.0 E-03$ & $1.0 E-02$ & 4. $0 E-03$ \\
\hline$U$ & $2.5 E-03$ & $3.4 E-01$ & $6.0 \vec{E}-04$ & $5.0 E-03$ & $6.0 E-04$ & $1.2 E-03$ \\
\hline No & $2.5 E-03$ & $2.0 E-03$ & $2.5 E-06$ & $5.0 E-03$ & $1.0 E-02$ & $4.0 E-03$ \\
\hline$P_{U}$ & $2.5 E-04$ & $2.0 E-03$ & $2.5 \mathrm{E}-08$ & $5.0 \mathrm{E}-03$ & $1.0 E-02$ & 4. $0 E-03$ \\
\hline An & $2.5 E-04$ & $2.0 E-03$ & $2.5 E-06$ & $5.0 E-03$ & 1. $C E-02$ & $4.0 E-03$ \\
\hline $\mathrm{Cm}$ & $2.5 E-03$ & 2.CE-03 & $2.5 E-06$ & $5.0 E-03$ & $1.0 E-02$ & 4. $0 E-03$ \\
\hline $\mathrm{Cf}$ & $2.5 E-03$ & $2.0 \mathrm{E}-03$ & $7.5 E-07$ & $5.0 E-03$ & $1.0 E-02$ & $4.0 E-03$ \\
\hline
\end{tabular}

(a) Where value uninown, a default value of $9.95-04$ was used. 


\section{Tritium and Carbon-14 Model}

Table 8 lists the parameters used in the computer program for tritium and ${ }^{14} \mathrm{C}$. These values may be altered based on site-specific data. The concentration of tritium or ${ }^{14} \mathrm{C}$ in environmental media (soil, plants and animal products) is assumed to have the same specific activity ( $\mathrm{pCi}$ of nuclide per $\mathrm{kg}$ of stable element) as the contaminating medium (air or water). The fractional content of hydrogen or carbon in a plant or animal product is then used to calculate the concentration of tritium or ${ }^{14} \mathrm{C}$ in the food product under consideration. Hydrogen content in both the water and nonwater (dry) portion of the food product is used to calculate the tritium concentration. The model assumes that plants obtain all their carbon from airborne carbon dioxide and that animals obtain all their carbon through ingestion of plants.

TABLE 8. Fractions of Hydrogen and Carbon in Environmental Media, Vegetation, and Animal Products

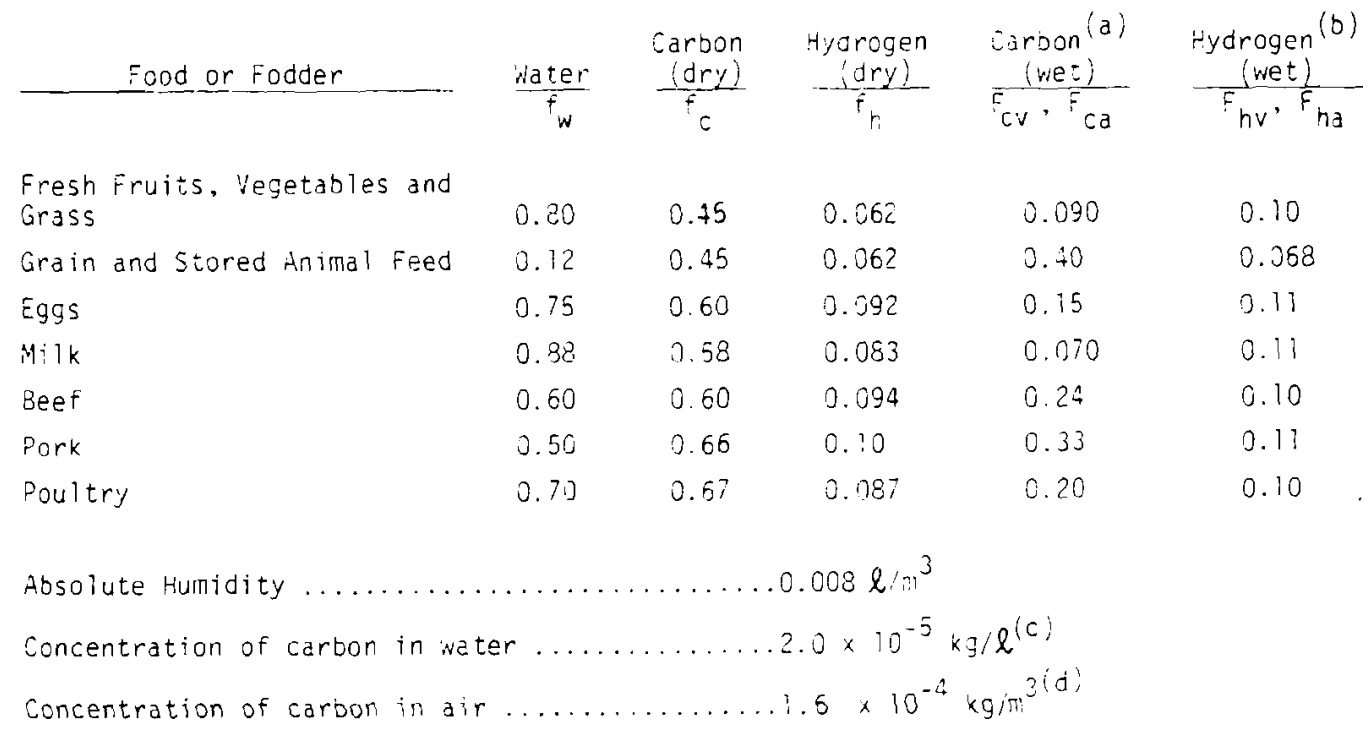
(a) $F_{C V}$ or $F_{C a}=f_{C}\left(1-f_{w}\right)$
(b) $F_{n v}$ or $F_{h a}=f_{w} / 9+f_{n}\left(1-f_{w}\right)$
(c) Assumes a typica? bicarbonate concentration of $100 \mathrm{mg} / \mathrm{l}$
(d) Assumes a typical atmospheric $\mathrm{CO}_{2}$ concentration of $320 \mathrm{Dom}_{\mathrm{v}}$. 
Because plants acquire most of their carbon from the air, it is difficult to model the transfer of this nuclide to vegetation when ${ }^{14} \mathrm{C}$ is present only in the water used for irrigation. Since we have not yet determined the transfer of carbon from water to the air or soil, we have conservatively assumed that plants obtain all their carbon from irrigation water. Such an assumption could lead to plant concentrations which are high by about an order of magnitude or more. To date no operating nuclear facilities have been identified which specify releases of ${ }^{14} \mathrm{C}$ in their liquid effluents. However, this pathway could exist from migration of ${ }^{14} \mathrm{C}$ into ground water from long-term storage of nuclear wastes.

The concentration of tritium in vegetation, $C_{7 v}$ is:

$$
c_{l v}=9 c_{l w} F_{h v}
$$

where

$C_{1 w}$ is the concentration of tritium in the environmental water $(\mathrm{pC} / \mathrm{l})$; for a water release $C_{i w}$ represents concentration in irrigation water; for an airborne release $C_{1}$ represents concentration in airborne moisture; For an airborne release: ${ }_{3} C_{1 w}=$ air concentration in $\mathrm{pCi}\left({ }^{3} \mathrm{H}\right) / \mathrm{m}^{3} \div$ absolute humidity in $\mathrm{l} / \mathrm{m}^{3}$.

$F_{\text {hv }}$ is the fraction of hydrogen in total vegetation (see Table 8 ). The coefficient 9 converts tritium concentration in environmental water to concentration in hydrogen.

The concentration of tritium in the animal product is:

$$
c_{1 a}=\left[\frac{C_{1 F} Q_{F}+c_{1 a w} Q_{a w}}{F_{h f} Q_{F}+Q_{a w} / 9}\right] F_{h a}
$$

where

$\mathrm{C}_{1 \mathrm{~F}}$ is the concentration of tritium in feed or forage $(\mathrm{pCi} / \mathrm{kg}) \mathrm{calcu}-$ lated by Eq. (14) above, where now $C_{1 F}=C_{1 v}$,

$F_{h F}$ is the fraction of hydrogen in animal feed, where now $F_{h f}=F_{h v}$
grain), 
$F_{h a}$ is the fraction of hydrogen in animal product (see Table 8), and

$C_{\text {law }}$ is the concentration of tritium in animal drinking water (set to 0 unless there is a release of water).

Similarly, the concentration of ${ }^{14} \mathrm{C}$ in vegetation is:

$$
c_{3 v}=c_{3 w} F_{C v}
$$

where

$\mathrm{C}_{3 \mathrm{~W}}$ is the concentration of ${ }^{14} \mathrm{C}$ in the environmental medium $\div$ carbon concentration in that medium $\left(\mathrm{pCi}{ }^{14} \mathrm{C} / \mathrm{kg} \mathrm{C}\right) . C_{3 w}$ represents $\mathrm{pCi}{ }^{14} \mathrm{C} / \mathrm{l} \div$ carbon concentration in irrigated water $(\mathrm{kg} / \mathrm{l})$ for water release and $\mathrm{pCi} 14 \mathrm{C} / \mathrm{m}^{3} \div$ carbon concentration in air $\left(\mathrm{kg} / \mathrm{m}^{3}\right)$ for air release, and

$F_{C V}$ is the fraction of carbon in total vegetation.

The concentration of ${ }^{14} \mathrm{C}$ in the animal product is:

$$
c_{3 a}=\left[\frac{c_{3 F} Q_{F}+c_{3 a w} Q_{a w}}{F_{c F} Q_{F}+F_{C w} Q_{a w}}\right] F_{c a}
$$

For an air release $C_{3 a w}=0$, and since $F_{C W}$ is very small compared to $F_{c f}$, Eq. (18) reduces to:

$$
c_{3 a}=c_{3 F}\left(\frac{F_{c a}}{F_{c F}}\right)
$$

Dose Calculations for Man

The dose, $R_{v r}$, in mrem to a person consuming vegetation is:

$$
R_{v r}=\sum_{i=1}^{n} c_{i v} u_{v} D_{i r}
$$


The dose from consuming a particular animal product is:

$$
R_{a r}=\sum_{i=1}^{n} C_{i a} U_{a} D_{i r}
$$

where

$U_{v}, U_{a}$ is the annual consumption of contaminated vegetable or animal
products in $\mathrm{kg}$, and

$D_{\text {ir }}$ is the factor which converts intake in $\mathrm{pCi}$ of nuclide $i$ to dose in
mrem to organ $r$.

\section{METHODOLOGY OF COMPUTING DOSE TO MAN}

The current project requires quantitative comparison of the combined radiation dose from various fuel cycle options. This should be done such that the entire set of dose calculation computer programs need not be rerun and summed for each fuel cycle alteration. To achieve this capability, the program will generate a combined dose-rate conversion factor for a specific organ of reference per unit nuclide released to air, water, or ground from a specific type of facility. Conversion factors will be generated for the maximum exposed individual as well as for populations. For example, for a maximum exposed individual adult living near the boundary of a fuels reprocessing plant, we will calculate the 50-yr dose commitments to the bone from an annual atmospheric release of $1 \mathrm{Ci}$ of ${ }^{90} \mathrm{Sr}$. The calculation will include dose contributions from the following pathways: inhalation, air sutmersion, exposure to contaminated ground, and consumption of produce, milk, eggs and meat contaminated via aerial deposition. These commitments will then be summed into a combined dose commitment conversion factor per unit release of ${ }^{90} \mathrm{Sr}$ to the air. The exposure to contaminated ground and consumption of foods depends on the length of time the reprocessing plant has been in operation. This study assumes that releases have been occurring for $15 \mathrm{yr}$ (one-half of the expected plant life). A similar combined dose commitment conversion factor incorporating all potential aquatic pathways will also be generated for a release rate of $1 \mathrm{Ci} / \mathrm{yr}$ of ${ }^{90} \mathrm{Sr}$ to surface water. 
Dose commitment conversion factors for other nuclides could also be generated. To determine the overall total dose commitment to an organ of a maximally exposed adult, the individual release rates of the various radionuclides to air (and water) would by multiplied by the proper dose commitment conversion factors and summed by a computer program. New release rates resulting from alterations in the fuel cycle could then be used with appropriate dose commitment conversion factors to calculate new doses without recalculating al1 the individual pathway doses. Modifications to the program listed in Table 2 to permit automatic summation of the doses from appropriate groups of pathways should be possible without serious difficulty. Such a scheme has already proven feasible on a limited scale for a combination of the programs ARRRG and FOOD.

Dose rate and commitment conversion factors for all radionuclides 1 isted in Table 3 will be generated. The 50-yr dose commitment will be determined for five organs of reference for an individual typical of those most highly exposed to the released effluents. This will involve multiplication of facility release rates of the several radionuclides to air (and water) by each respective dose rate and commitment conversion factor and then summed over all released radionuclides. Altered release rates resulting from modification of either fuel or fuel cycle facilities can then be used to recalculate annual doses and dose commitmentments without recalculating all the individual pathway doses.

Dose-rate conversion factors will be used to generate annual doses to compare with proposed EPA Environmental Standards. (17) As previously mentioned, environmental activity from routine releases tends to increase at an ever-decreasing rate until eventually an equilibrium activity level is established. The time required to establish equilibrium depends on several factors, including radioactive half-life, weathering, and the characteristics of pathways. The longer the time required to reach equilibrium, the higher the environmental concentrations. Since this study assumes releases of $15 \mathrm{yr}$ and no credit for weathering, the calculated environmental levels will exceed equilibrium values for all but the least weathered and longest lived radionuclides. 
The fractional contribution by nuclide to annual dose rate from a11 radionuclides and all pathways considered will be used as an index to determine the relative importance of the effluents and their relative contribution to dose to people.

Finally, dose conversion factors for populations will be generated. Two sets of factors are required, one for each of two generic sites. These factors are site-dependent because they are based on site characteristics such as demography, climatology, hydrology, and land use.

In summary, dose commitment and annual dose conversion factors for maximum exposed individuals will be determined for five organs of reference. The fractional contribution to annual dose by radionuclide for individuals will be determined for each organ of reference. Population dose conversion factors will be generated for each of two generic sites.

\section{LIMITATIONS OF METHODOLOGY}

Limitations which affect the accuracy of the results should be recognized and considered when subsequent calculations, evaluations and recommendations are made. These limitations affect the estimated degree of required environmental control as well as the ranking of various radioactive effluents and sources for each facility. No attempt has been made to estimate the overall error due to these limitations, for it is different for each case.

\section{Limitations of Approach}

The approach outlined is limited in that it does not

- consider occupational exposure

- evaluate accidental or intermittent releases

- evaluate the impact of solid wastes

- evaluate the impact of radioactive effluents on groundwater quality

- directly estimate health and welfare effects. 


\section{Qual ity of Data}

The accuracy of the input data varies in the following manner:

- Process effluent emission factors may be in error by a factor of 10 or more. Most of this information is based on calculations using estimated parameter values and not on specific measurements.

- Meterology and hydrology data are more typical of a region than representative of the exact conditions surrounding existing and future facilities.

- The environmental permissible concentrations and dose criteria accurately reflect present regulations and standards but these are subject to continuous review and may change accordingly.

\section{Accuracy of Calculation Procedures}

The calculation methods have the following accuracy:

- Ambient concentrations estimated by the dispersion models are accurate within a factor of about 10 .

- There is no way of determining the accuracy of the dose models. The models, however, reflect the state-of-the-art and wherever possible rely on the recommendations of the International Commission on Radiological Protection and the National Council on Radiation Protection and Measurements. 


\section{ASSESSMENT METHODOLOGY FOR CHEMICAL EFFLUENTS}

The objective of this environmental assessment is to define the present and future needs for controlling chemical effluents from nuclear fuel cycle facilities. These needs are defined by the environmental requirements for human health and welfare. Environmental quality standards are used to assess environmental impact and to calculate the degree of control required for specific chemical effluents.

The environmental assessment of chemical effluents would be quite straightforward if emission standards and/or control equipment specifications existed for each chemical effluent and source. In recent years federal laws on water and air pollution have developed some regulations of this nature. However, the regulations do not cover all of the chemical effluents emitted from nuclear fuel cycle facilities. Development of additional regulations is presently hampered by the lack of specific knowledge about the pathways, uptake, and responses to these chemicals. No recognized methodology presently exists which can be used to directly compute the environmental impact of chemicals. This absence of a standard methodology leaves many unresolved problems :

1. Chemical pollutants cause a multitude of effects, but the damage functions, i.e., the factors relating to concentration and duration of exposure to a specified effect, are not known.

2. The many synergistic effects that probably occur have not been adequately documented. Furthermore, it is difficult to separate these effects from other environmental factors.

3. Chemicals often undergo reactions in the environment after release. The effect of the new chemical may be more or less detrimental than the original species. It is difficult to predict such changes in time and space with multicomponent systems. 
Despite the fact that no methodology has yet been developed to address all these problems, environmental assessments are still necessary and beneficial. Methodologies (see Appendix $D$ for references) have been developed to 1) assess the overall environmental impact of a new facility or technology, 2) compare two or more energy technologies, and 3) assess the potential hazard of chemicals. These methodologies have been reviewed and evaluated for possible use in this study. Since none of the referenced methodologies directly meet the needs of this project, only parts of these methods were used to develop the described procedure.

\section{THE APPROACH}

Chemical effluents may individually or in combination cause detrimental effects if they are not adequately controlled. For this reason two types of environmental assessments are made: 1) chemical/source analyses and

2) facility analyses. First, all sources of chemical effluents are evaluated individually. Source performance (effluent) standards, ambient environmental quality standards and toxicological standards and data are used to determine the extent of control required for each chemical and source combination. These standards are presented in Appendixes $B$ and $C$. A detailed list of the sources and chemicals that require environmental control is developed by comparing estimated concentrations with the appropriate environmental standard. The degree of control required is also computed. After this has been completed, each complete facility (mining, milling, conversion, enrichment, etc.) receives an overall environmental assessment, thus evaluating the additive effect of a number of sources of chemical effluents at one facility. It identifies any additional environmental control required for the facility.

The impact of environmental control requirements on the cost of electricity depends on:

- when the control is required,

- where the control must be applied, and

- what degree of control is needed. 
The chemical/source analyses and the facility analyses provide information on "where" and "what degree." Several scenarios may be evaluated to determine "when" the control is required.

\section{SOURCE/CHEMICAL ANALYSIS}

Effluent, ambient and toxicological environmental standards are used to evaluate the need for environmental control for each source/chemical combination. The methodology for this anlaysis is shown as a flow diagram in Figure 2. First, effluent standards are compared with the estimated emission rates. This direct comparison provides a simple method for calculating the degree of control required. If effluent standards are not available, a second approach using ambient standards is used. The need for environmental control is based on the relative impact of the chemical from each source. If neither effluent nor ambient standards exist for a chemical, toxicological data are used to estimate acceptable ambient limits. Then the impact of each source/ chemical is assessed and the need for environmental control determined. The first method is preferred since it is specific to the problem and the effluent standards have withstood the test of scientific review. Toxicology standards and data are used to estimate acceptable limits only when neither effluent nor ambient standards are available.

Methodology Based on Effluent Standards

Effluent standards are compared with the estimated effluent emission rates. The effluent descriptions are being generated as part of the facility description documents. This direct comparison provides a simple method for calculating the degree of control required.

$$
N_{C}=\left[\frac{E R-E S}{E S}\right] \times 100
$$

where

$N_{C}$ is the required control efficiency, $\%$,

$E R$ is the existing effluent rate from the source,

ES is the effluent standard. 


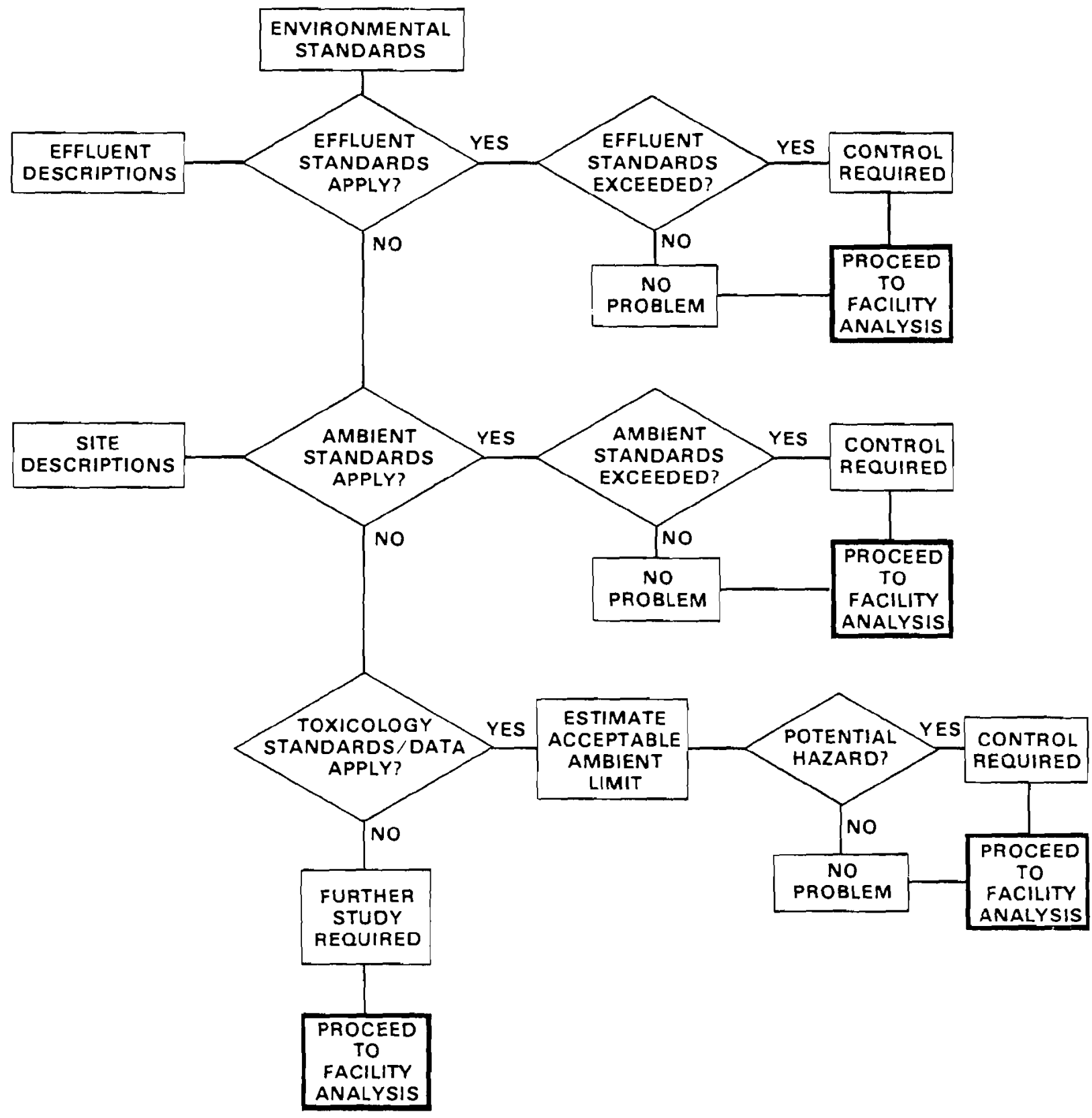

FIGURE 2. Methodology for Source/Chemical Analys is 
If the effluent rate is less than effluent standard, then the source chemical is in compliance and additional control may not be required.

This first-stage evaluation provides three lists:

1. List of sources/chemicals that require control because they violate effluent standards

2. List of sources/chemicals which meet the standards

3. List of sources/chemicals for which there are no effluent standards.

The content of these lists depends on time. Some source/chemical combinations may not require control now but will in the future. New regulations will probably be promulgated and implemented. Hence future requirements for environmental control technology must be estimated. Future effluent limits for various processes may be estimated on the basis of existing standards for similar industrial processes. For example, the present standard for oxides of nitrogen effluent for nitric acid plants is a good gauge for what to expect in the future for hot nitric acid dissolution operations in fuel reprocessing. Methodology Based on Ambient Standards

If effluent standards are not available for a source/chemical combination, then its impact will be assessed by comparing calculated ambient concentrations with ambient standards. Pertinent hydrological and meteorlogical data are available from the site descriptions for each facility to permit such calculations.

This second-stage evaluation provides three lists:

1. List of sources/chemicals that require control because they cause significant deterioration of ambient conditions or violate ambient standards

2. List of sources/chemicals which are not expected to cause any significant environmental impact

3. List of sources/chemicals for which there are no ambient standards. 


\section{Gaseous Effluents}

Effluent and site data are used to calculate the expected ambient air concentrations. The ambient air quality standards for sulfur dioxide, particulate matter, carbon monoxide, oxidant, oxides of nitrogen and hydrocarbons are given in Appendix $B$. These standards were promulgated by the EPA under the Clean Air Act. The establishment of these standards does not mean that air quality should be allowed to deteriorate significantly in any location with cleaner air. EPA defined "significant deterioration" for sulfur oxides and particulate matter. These data and the numbers derived for oxides of nitrogen, carbon monoxide and hydrocarbons are shown in Table 9. The allowed increase in annual arithmetic mean for sulfur dioxide is equal to $18 \%$ of its ambient air quality standard. Using this percentage, an allowed increase of $18 \mathrm{ug} / \mathrm{m}^{3}$ is estimated for oxides of nitrogen. The allowed increase in $24-\mathrm{hr}$ and $3-h r$ concentrations for sulfur dioxide is equal to $40 \%$ and $50 \%$ of the secondary ambient air quality standard, respectively. Hence a $50 \%$ factor was used to estimate values for carbon monoxide and hydrocarbons.

Thus the degree of control required may be calculated

$$
N_{C}=\left[\frac{C A C-S D I}{S D I}\right] \times 100
$$

where

$\mathrm{N}_{\mathrm{C}}$ is the required control efficiency, $\%$,

CAC is the calculated ambient concentration caused by the effluent,

SDI is the maximum allowed increase in ambient concentration without causing significant deterioration of air quality.

NRC model XOQDOQ will be used to estimate ambient concentrations caused by gaseous chemical effluents. This computer code is used by NRC in its evaluation of routine atmospheric releases from commerical nuclear power reactors. (19) It has been used in evaluations connected with Appendix I of 10 CFR Part 50 of the Code of Federal Regulations. 
For routine releases, the code calculates average normalized air concentrations and average normalized deposition values at locations specified by the user. The code has the following options:

1. The release point of the effluent plume can be assumed to be

a. always elevated,

b. always ground level, or

c. a mixed mode (elevated and ground-level sources).

2. The effluent plume for elevated releases can undergo plume rise due to buoyancy or momentum.

3. Ground-level releases can be affected by the additional local dispersion due to building wakes.

4. Wind speeds measured at one elevation may be extrapolated to other elevations with a power law expression.

5. Effect of topography on air concentrations can be estimated.

6. The plume may correct for radioactive decay (it is possible to estimate chemical decay by using an exponential term).

7. The plume may be depleted via dry deposition.

8. The average normalized ground-level air concentrations and average normalized deposition values may be amended to reflect the effects of local air recirculation or stagnation.

The NRC computer code calculates the annual average normalized concentrations, $X / Q$, for 16 wind direction sectors. However, the ambient air standards for some species are for shorter time periods, e.g., 1, 3, 8, and $24 \mathrm{hr}$. Short term $X / Q$ values will be obtained in the following manner. Assuming a log-normal distribution of the individual $X / Q$ values for every wind speed and stability category in the wind direction sector with the highest annual average, a $7 \%$ value will be calculated. This $1 \%$ represents that value on the log-normal distribution such that concentrations higher than it would 
not occur more than $1 \%$ of the time. Using this 1\% value as the highest $1-h r$ concentration, a straight line on log-log paper will be drawn through the annual average value. Estimates of other short term $X / Q$ values can be made from this graph. Note that these results are also dependent on release height and distance from the source.

\section{Liquid Effluents}

Water quality criteria are published by the EPA. The quality requirements vary according to the use. The most critical water quality criteria for each chemical are presented in Appendix $C$. Effluents from any facility must meet these criteria after passing through a suitable mixing zone; otherwise further environmental control is necessary. Control is required if

$$
\frac{x_{m}}{x_{q}}>1
$$

or

$$
\frac{x_{e} D F}{x_{q}}>1
$$

where

$$
\begin{aligned}
& x_{m} \text { is the estimated concentration after dilution (mixing), } \\
& x_{e} \text { is the effluent concentration, } \\
& D F \text { is the dilution factor in the receiving environment, } \\
& x_{q} \text { is the critical water quality criteria. }
\end{aligned}
$$

The dilution factor is determined by the mixing characteristics of the receiving body; for instance, dilution is slower in a reservoir or estuary than in a river. A dilution factor will be estimated for each source/ chemical combination. The need for environmental control can then be determined. 
A computer code, PIONEER, $(20)$ is used to predict the dispersion and effect of chemicals in surface waters. It can be used for streams, rivers, shallow lakes, estuaries or tidally influenced rivers. The code has the following characteristics:

1. It can describe the spatial and temporal variations of 16 water quality parameters, including biochemical oxygen demand, phosphorus, ammonia nitrogen, and toxic compounds.

2. It can simulate diurnal or long-term periods.

3. It can handle constant and time-varying point or diffuse sources.

4. It provides steady-state predictions.

With respect to toxic compounds the PIONEER code does not predict the interaction with sediments, biota and other constituents. In fact, suitable codes do not exist for this. PIONEER uses a simple $n^{\text {th }}$ order decay to describe the rate of change for toxic compounds. The cause of decay may be a number of mechanisms including chemical transformation, sedimentation, biological uptake and sorption. The rate of change is described by:

$$
\frac{d T_{c}}{d t}=-a T_{c}^{n}
$$

where

$T_{c}$ is the concentration of the toxic compound at time, $t$,

a is the rate constant, and

$n$ is the order of decay.

Methodology Based on Toxicological Standards and Data

Toxicological standards and data presented in Appendixes $B$ and $C$ will be used if neither effluent nor ambient standards exist for a chemical effluent. The toxicological standards consist of Threshold Limit Values (TLVs) for exposure of humans to gases and aerosols and oral lethal dose 
concentrations $\left(L D_{50}\right)$ for rats. (a) These data are used to estimate acceptable limits for humans. These estimated limits are then used in the computational procedures described previously to assess the need for environmental control technology.

The third-stage evaluation provides three lists:

1. List of sources/chemicals that require control because they pose a potential hazard even though they do not violate any existing standards

2. List of sources/chemicals that do not pose any apparant environmental hazard

3. List of sources/chemicals for which toxicological data are insufficient and should thus be studied further.

Handy and Schindler(21) have developed methods for estimating permissible pollutant concentrations for continuous exposure using $T L V S$ and $L D_{50} S$. Correlations were also made for TLV and $L D_{50}$ values such that one type of data could be used in place of the other. While such calculated values are not ambient standards, they do represent the best available estimate for acceptable limits. Handy and schindler developed the following relationships:

For gaseous effluents,

$$
x_{p}=\left(1.65 \times 10^{-3}\right)[\text { TLV }]
$$

where

$x_{p}$ is the maximum permissible air concentration $\left(\mathrm{mg} / \mathrm{m}^{3}\right)$, arid

$T L V$ is the threshold limit value in air $\left(\mathrm{mg} / \mathrm{m}^{3}\right)$.

(a) The TLV is the acceptable air concentration of $8 \mathrm{hr} / \mathrm{day}, 40 \mathrm{hr} /$ week exposure without any adverse health effects to a healthy worker. The TLV values are set by the American Conference of Governmental Industrial Hygienists.

The LD50/14 or median lethal dose represents the dose level which is lethal to half of the test population. Hence, if $10^{6}$ rats are fed this dose, 500,000 will most probabiy die over the 14-day observation period. The dose itself is applied during a 24-hr period and is measured in terms of $\mathrm{mg}$ of materials per $\mathrm{kg}$ body weight. Oral doses to rats are the most common data available and hence used for this project. 
For most organic and inorganic compounds in drinking water,

$$
x_{e}=\left(4.0 \times 10^{-4}\right)\left[L_{50 / 14}\right]
$$

but if $L D_{50 / 14}$ is unknown,

$$
x_{e}=\left(1.38 \times 10^{-2}\right)[\text { TLV }]
$$

where

$x_{e}$ is the maximum acceptable concentration ( $\mathrm{mg} / \mathrm{l}$ ), and

$\mathrm{LD}_{50 / 14}$ is the lethal dose for $50 \% \mathrm{kill}$ of rats $(\mathrm{mg} / \mathrm{kg})$ in 14 days.

For those compounds in drinking water that are retained in the body for long periods ( 1 -yr biological half-life)

$$
x_{e}=\left(3.3 \times 10^{-5}\right)\left[\mathrm{LD}_{50 / 14}\right]
$$

but if $\mathrm{LD}_{50 / 14}$ is unknown,

$$
x_{e}=\left(1.14 \times 10^{-3}\right)[\text { TLV }]
$$

For compounds in drinking water for which the biological half-life for man is known

$$
x_{e}=\frac{0.012\left[\mathrm{LD}_{50 / 14}\right]}{\tau}
$$

where

$\tau$ is the biological half-life in man (days).

These expressions are used to estimate acceptable ambient limits where they are needed. The estimation methods consider the most sensitive parts of the population. That is, they protect young and elderly. In most cases the 
expressions predict acceptable limits lower than existing ambient standards. For example, Eq. (27) estimates an acceptable limit for nitrogen dioxide that is almost 7 times lower than the current ambient air quality standard.

The concept of using toxicological standards and data to estimate acceptable ambient 1 imits has been used by Eimutis $(22,23)$ to assess the relative impact severity of various sources of air pollution. The TLV was proportionally adjusted for different exposure periods and then a safety factor of 100 was applied. The work of Handy and Schindler will be used to estimate acceptable limits for any chemical that does not have an ambient standard. This method was selected in preference to Eimutis' method because its estimated ambient limit values are more stringent.

\section{FACILITY ANALYSIS}

After the source/chemical analysis is completed, each facility receives an overall environmental assessment. The objectives of this assessment are:

- to evaluate the combined effect of multiple chemical pollutants

- to rank the environmental control technology needs for each facility

- to assess the potential large-scale effects of each facility.

The ambient and toxicological standards are used as the basis for evaluation. The XOQDOQ and PIONEER computer codes are used to compute ambient chemical concentration profiles for each facility. The results are then compared to the ambient standards and/or the nondegradation criteria previously described. If these are exceeded, then additional environmental control will be necessary. In that case the computer codes may be used as simulation models to determine the effect of various control strategies for each facility. Multiple Chemical Effects

The evaluation of multiple chemicals is complicated by the possibility of different responses: for example, independence, additivity, synergism or antagonism. If the effect of a chemical species is independent, then it should be evaluated according to the methods described previously. If two 
or more chemicals cause similar effects, they may be treated in an additive manner. If the resultant effect is greater than the simple additive effect, it is said to be synergistic. If the resultant effect is less than the additive amount, it is antagonistic. Additivity is assumed for this evaluation. However, if synergistic effects seem possible, they will be noted for further study.

The effect of a chemical can be estimated by comparing its concentration with a standard. For a two-component system then the combined effect is $C A C_{1}+C A C_{2}$ and to be acceptable the following criterion must be met

$$
\frac{\mathrm{CAC}_{1}}{\mathrm{AS}_{1}}+\frac{\mathrm{CAC}_{2}}{\mathrm{AS}_{2}}<1
$$

where

CAC is the calculated ambient concentration, and

AS is the ambient standard.

The environmental quality is assumed to be acceptable as long as the sum does not exceed 1. Thus for all locations surrounding each facility, the following conditions must be met:

$$
\sum_{i=1}^{N} \sum_{j=1}^{k} \frac{C A C_{i j}}{A S_{j}}+\sum_{j=1}^{k} \frac{B G C_{j}}{A S_{j}}<1
$$

where

$N$ is the number of sources,

$K$ is the number of chemical species,

$C A C_{i j}$ is the calculated ambient concentration of species $j$ from source $i$,

$A S_{j}$ is the ambient standard for chemical species $j$ (estimated acceptable limits will be used if standard does not exist), and

$B_{j}$ is the background concentration of chemical species $j$. 
The approach presented in Eq. (34) is similar to the one recommended by the American Conference of Governmental Industrial Hygienists (24) for use with Threshold Limit Values. Eimutis ${ }^{(23)}$ made the same assumption when he developed a method to rank the severity of air pollution sources in the United States.

If Eq. (34) does not hold at a location, then the relative contribution of each chemical/source combination, and hence its priority for environmental control, will be calculated as follows:

$$
R C_{i j}=\frac{\frac{C A C_{i j}}{A S_{j}}}{\sum_{i=1}^{N} \sum_{j=i}^{K} \frac{C A C_{i j}}{A S_{j}}+\sum_{j=1}^{K} \frac{B G C_{j}}{A S_{j}}}
$$

where

$R C_{i j}$ is the relative contribution of source $i$ to the pollution caused
by chemical species $j$. At a given location, the relative contribution of source $i$ is obtained by summing over all species emitted by the source.

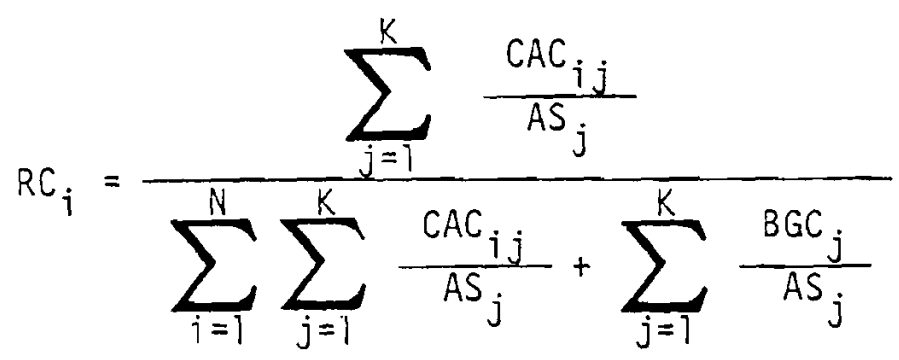

where

$R C_{i}$ is the relative contribution of source $i$ to the pollution caused by all chemical species at the location of interest.

The sources will be ranked for environmental control technology according to their calculated values of $R C_{i j}$ and $R C_{i}$. 
Nondegradation of ambient air quality is an additional assessment requirement. If the background air is cleaner than the standards, then it may not be degraded any further. Thus, where $B G C_{j} \ll A S_{j}$, the following must hold for each chemical species $j$ and at all locations surrounding the facility:

$$
\sum_{i=1}^{N} \frac{\mathrm{CAC}_{i j}}{\mathrm{SDI}_{j}}<1
$$

where

$$
\begin{aligned}
& \text { CAC }_{i j} \text { is the calculated ambient air concentration of species } j \text { from } \\
& \text { source } i \text {, and } \\
& \text { SDI }_{j} \text { is the defined significant degradation increment for species } j .
\end{aligned}
$$

Some SDI values are presented in Table 9. Values for other chemical species will be estimated as needed for this calculation. In this case the sources will be ranked for environmental control technology according to their estimated relative contribution to air pollution at the location.

It is possible that the ambient environmental quality expressions, Eq. (34) and (37) are exceeded (greater than 1) at more than one location. In this case the computer codes may be used to assess the various control strategies that might be used. Several control strategies may be suitable for meeting the environmental constraints; however, this determination is not within the scope of this task.

\section{Large-Scale Effects}

The assessment procedures previously described are not intended to evaluate large-scale effects. The calculation methods focus on effects and local impacts; however, it is possible that some large-scale effects may occur. Chemicals may undergo reactions and form secondary species of even greater hazard than the original effluent. This may occur at considerable distances 
TABLE 9. Increases in Air Pollution that Represent Significant Deterioration

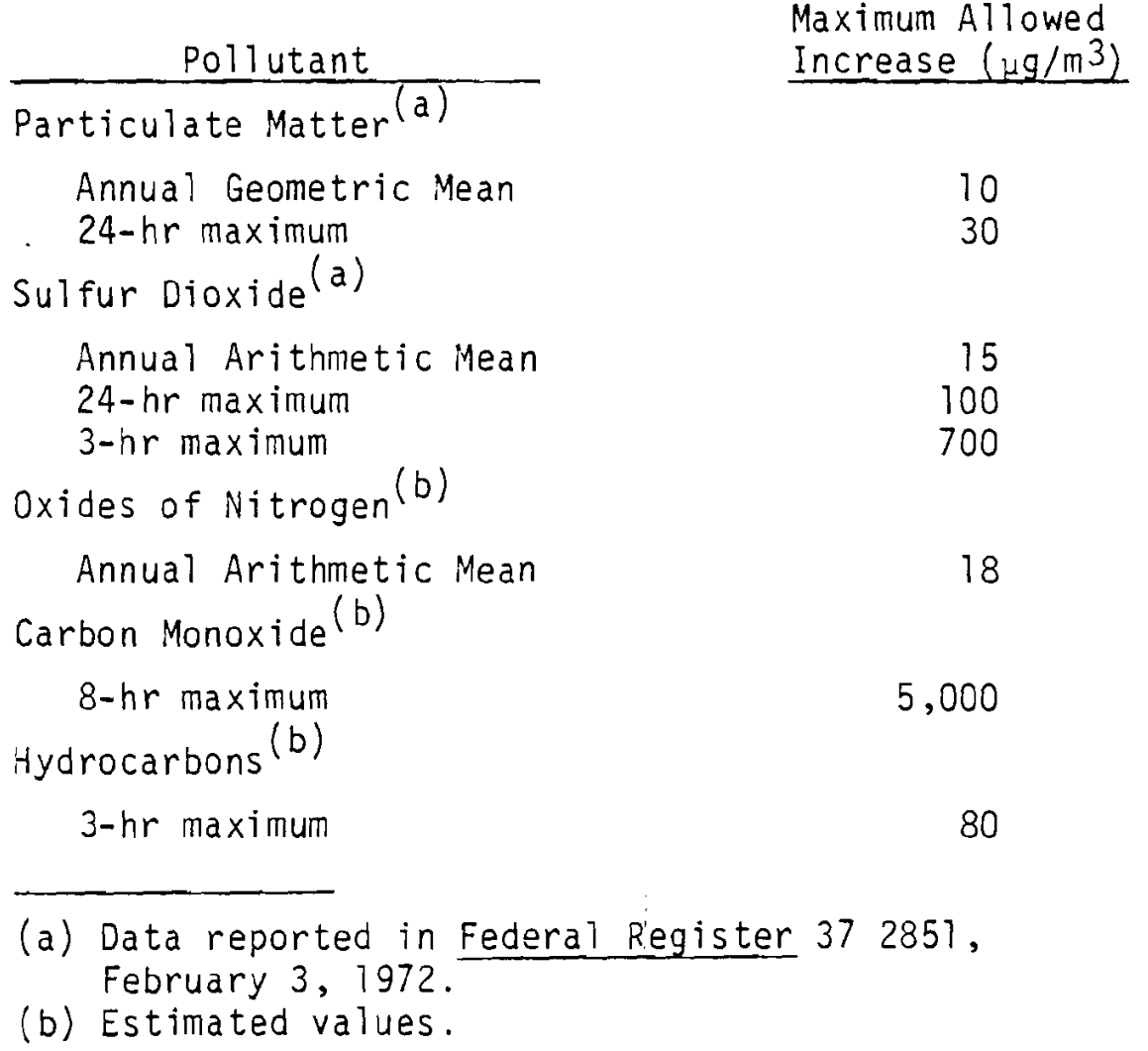

from the source. The initial phases of the environment assessment work will determine if any chemical effluents are of sufficient magnitude to cause such an impact. One possibility is the atomospheric conversion of sulfur dioxide to particulate sulfates. Recent epidemiological studies have suggested that particulate sulfates are highly correlated with many respiratory ailments. (25) If this problem or a similar one occurs, different computer codes will be sought, evaluated and used as required. The work of Hales et al. (26) and Wendell et al. (27) provide a starting point for this evaluation. 


\section{LIMITATIONS OF METHODOLOGY}

Many limiting factors in the methodology affect the accuracy of the results. For instance, they definitely affect the estimated degree of required environmental control and the ranking of various chemical effluents and sources for each facility. These limitations should be recognized and considered when subsequent calculations, evaluations and recommendations are made. No attempt has been made to estimate the overall error due to these limitations, for it is different for each case.

\section{Limitations of Approach}

The approach outlined is limited in that it does not

- consider occupational exposure

- evaluate accidental or intermittent releases

- evaluate the impact of solid wastes

- evaluate the impact of thermal discharges

- evaluate the impact of chemical effluents on groundwater quality

- directly estimate health and welfare effects.

Quality of Data

The accuracy of the input data varies in the following marner:

- Process effluent emission factors may be in error by a factor of 10 or more. Most of this information is based on calculations and estimates and not on specific measurements.

- Meteorological and hydrological data are more typical of a region than representative of the exact conditions surrounding existing and future facilities.

- The environmental standards and toxicology data reflect the state-ofthe-art but these data are subject to continuous review and may change accordingly. 
Accuracy of Calculation Procedures

The calculation methods have the following accuracy:

- Ambient concentrations estimated by the dispersion models are accurate within a factor of about 10 .

- The methods of Handy and Schindler ${ }^{(21)}$ for estimating acceptable ambient limits are accurate within a factor of 10 . 


\section{REFERENCES}

1. J. K. Soldat, N. M. Robinson and D. A. Baker, Models and Computer Codes for Evaluating Environmental Radiation Doses, BNWL-1754, Battelle, Pacific Northwest Laboratories, Richland, WA, 1974.

2. D. A. Baker, G. R. Hoenes and J. K. Soldat, FOOD - An Interactive Code to Calculate Internal Radiation Doses from Contaminated Food Products, BNWL-SA-5523, Battelle, Pacific Northwest Laboratories, Richland, WA, 1976.

3. D. A. Baker, User Guide for Computer Program F000, BNWL-2209, Battelle, Pacific Northwest Laboratories, Richland, WA, 1977 (in press).

4. U.S. Nuclear Regulatory Commission, "Calculation of Annual Doses to Man from Routine Releases of Reactor Effluents for the Purpose of Evaluating Compliance with 10CFR50, Appendix I," Regulatory Guide 1.109, Office of Standards Development, Washington, DC (for comment), March 1976.

5. J. K. Soldat, Modeling of Environmental Pathways and Radiation Doses. from Nuclear Facilities, BNWL-SA-3939, Battelle, Pacific Northwest Laboratories, Richland, WA, 1971.

6. J. F. Fletcher and W. L. Dotson (compilers), HERMES - A Digitai Computer Code for Estimating Regional Radiological Effects from the Nuclear Power Industry, HEDL-TME-71-168, Hanford Engineering Development Laboratory, Richland, WA, 1971.

7. International Commission on Radiological Protection, Report of ICRP Committee I I on Permissible Dose for Internal Radiation, ICRP Publication 2, Pergamon Press, NY, 1959.

8. S. E. Thompson, C. A. Burton, D. J. Quinn and Y. C. Ng, Concentration Factors of Chemical Elements in Edible Aquatic Organisms, UCRL-50564 Rev. 1, University of California, Lawrence Livermore Laboratory, October 1972.

9. A. M. Freke, "A Model for the Approximate Calculation of Safe Rates of Discharge of Radioactive Wastes into Marine Environments, "Health Physics, Vol. 13, No. 743, 1965.

10. J. L. Nelson, "Distribution of Sediments and Associated Radionuclides in the Columbia River Below Hanford, "Hanford Radiological Sciences Research and Development Annual Report for 1964, BNWL-36, (D. W. Pearce and J. K. Green, Eds.), Battelle, Pacific Northwest Laboratories, Richland, WA, p. $3.80,1965$. 
11. G. L. Toombs, P. B. Culter (compilers), Comprehensive Final Report for the Lower Columbia River Environmental Survey in Oregon June 5, 1961 July 31, 1967, Oregon State Board of Health, Div. of Sanitation and Engineering, Portland, OR, 1968.

12. Handbook of Radiological Protection, Part I: Data, prepared by a Panel of the Radioactivity Advisory Committee, (H. J. Dunster, Chairman), Dept. of Employment, Dept. of Health and Social Security, Ministry of Health and Social Services, Northern Ireland, number SBN 113600798 , Her Majesty's Stationery Office, London, England, 1971.

13. D. H. Slade (Ed.), Meteorology and Atomic Energy - 1968, USAEC Division of Technical Information Extension, Oak Ridge, TN, 1968.

14. Y. C. Ng et al., Prediction of the Maximum Dosage to Man from the Fallout of Nuclear Devices - IV, Handbook for Estimating Maximum Interna] Dose from Radionuclides Released to the Biosphere, UCRL-50163, Lawrence Radiation Laboratory, University of California, Livermore, CA, 1968.

15. F. R. Mraz et al., "Fission Product Metabolism in Hens and Transference to Eggs," Health Physics, no. 10, pp. 77-782, 1964.

16. I. K. Annenkov et al., The Radiobiology and Radioecology of Farm Animals, AEC-tr-7523, Apri1 1974.

17. Environmental Radiation Protection Standards for Nuclear Power Operations, Federal Register, Vol. 42, No. 9, pp. 2858-2861, January 13, 1977.

18. "Approval and Promulgation of Implementation Plans," Federal Register 37 FR 2581, February 3, 1972.

19. J. F. Sagendorf and J. T. Gol1, "X0Q00Q Program for the Meteorological Evaluation of Routine Effluent Releases at Nuclear Power Stations," U.S. Nuclear Regulatory Commission, Washington, DC, August 1976.

20. Development of a Mathematical Water Quality Model for Grays Harbor and the Chehalis River, Washington, Documentation Report 211901360 for U.S. Environmental Protection Agency, Battelle Northwest Laboratories, Richland, WA, October 1974.

21. R. Handy and A. Schindler, "Estimation of Permissible Concentrations of Pollutants for Continuous Exposure," U.S. Environmental Protection Agency, EPA/600/2-76/155, Research Triangle Park, NC, June 1976.

22. E. C. Eimutis, B. J. Holmes and L. B. Mote, "Source Assessment: Severity of Stationary Sources - A Simulation Approach," U.S. Envirormental Protection Agency, 600/2-76-032e, Research Triangle Park, NC, July 1976. 
23. E. C. Eimutis, "Source Assessment: Priorization of Stationary Air Pollution Sources - Model Description," U.S. Environmental Protection Agency, EPA 600/2-76/032a, Research Triangle Park, NC, February 1976.

24. "Threshold Limit Values for Chemical Substances and Physical Agents in the Workroom Environment with Intended Changes for 1976," American Conference of Governmental Industrial Hygienists, Cincinnati, OH, 1976.

25. "Health Consequences of Sulfur 0xides: A Report from CHESS," U.S. Environmental Protection Agency, EPA-650/1-74-004, Research Triangle Park, NC, May 1974.

26. J. M. Hales, D. C. Powe11, T. D. Fox, "STRAM--An Air Pollution Model Incorporating Non-Linear Chemistry, Variable Trajectories, and Plume Segment Diffusion," (in preparation), Battelle, Pacific Northwest Laboratories, Richland, WA.

27. "A Regional Scale Model for Computing Deposition and Ground Level Air Concentrations of $\mathrm{SO}_{2}$ and Sulfates from Elevated and Ground Sources," Third Symposium of Atmospheric Turbulence, Diffusion and Air Quality, 1976. 

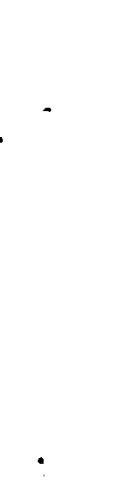


\section{APPENDIX A}

ENVIRONMENTAL STANDARDS FOR RADIOACTIVE EFFLUENTS 
APPENDIX A

\section{ENVIRONMENTAL STANDAROS FOR RADIOACTIVE EFFLUENTS}

The objective of this appendix is to identify the environmental radiation standards that apply to nuclear fuel cycle facilities. Such standards may be used as the basis for determining the need for environmental control technology at such facilities. Tables A-1 through A-10 list the radioactive effluents from each of the facilities.

Two Federal organizations are presently involved in the development of radiation standards: The Nuclear Regulatory Commission (NRC) and the Environmental Protection Agency (EPA).

\section{NUCLEAR REGULATORY COMMISSION'S RADIATION STANDARDS}

The NRC and its predecessors in the Atomic Energy Commission have been developing radiation standards for almost 30 years. The NRC derives its authority from two principal sources: The Atomic Energy Act of 1954 and the National Environmental Policy Act of 1969 (NEPA).

The Energy Reorganization Act of 1974 transferred the regulatory authority of the Atomic Energy Act to the NRC. This includes the authority to issue licenses to persons making commercial application of nuclear power. Licenses are issued based upon findings that such persons meet safety standards to protect health and to minimize danger to life or property.

Pursuant to the National Environmental Policy Act, the NRC requires a detailed statement on the environmental impact of major nuclear facilities. Applicants propose and justify the cost effectiveness of a site and plant design combination relative to other alternatives. NRC reviews the proposals and then approves, disapproves, or specifies additional requirements necessary.

Title 10, Part 20 of the Code of Federal Regulations (CFR) ${ }^{(1)}$ contains NRC's basic regulations that provide environmental radiation standards and performance limits within which nuclear power reactors must be operated. 
This regulation limits the concentrations of radionuclides in air and water to which individuals may be exposed. No other absolute numerical limits or standards have been promulgated by NRC. However, in Appendix I of Part 50 NRC does provide guidelines for what it considers good practice for design and operation of power plant facilities. ${ }^{(2)}$ These guidelines are 1 isted as follows:

A.1 The calculated annual total quantity of all radioactive material from all light-water-cooled nuclear power reactors at a site should not result in an annual dose or dose commitment to the total body or to any organ of an individual in an unrestricted area from all pathways of exposure in excess of 5 millirems; and

A.2 The calculated annual total quanity of radioactive material, except tritium and dissolved gases, should not exceed 5 curies for each light-water-cooled reactor at a site.

A.3 Notwithstanding the guidance in paragraph A.2, for a particular site, if an applicant for a permit to construct a light-water-cooled nuclear power reactor has proposed baseline in-plant control measures $(a)$ to reduce the possible sources of radioactive material in liquid effluent releases and the calculated quantity exceeds the quantity set forth in paragraph A.2, the requirements for design objectives for radioactive material in liquid effluents may be deemed to have been met provided:

(a) the applicant submits an evaluation of the potential for effects from long-term buildup in the environment in the vicinity of the site of radioactive material, with a radioactive half-iife greater than one year, to be released; and

(b) the provisions of paragraph A.1 are met.

(a) Such measures may include treatment of clear liquid waste streams (normaily tritiated, nonaerated, low conductivity equipment drains and pump seal Teakoff), dirty iiquid waste streams (normally nontritiated, aerated, high conductivity building sumps, floor and sample station drains), steam generator blowdown streams, chemical waste streams, low purity and high purity liquid streams (resin regenerate and laboratory wastes), as appropriate for the type of reactor. 
B. 1 The calculated annual air dose due to ganma radiation at any location near ground level which could be occupied by individuals at or beyond the boundary of the site should not exceed 10 millirads; and

B.2 The calculated annual air dose due to beta radiation at any location near ground level which could be occupied by individuals at or beyond the boundary of the site should not exceed 20 millirads.

8.3 Notwithstanding the guidance in paragraphs 8.1 and B.2, for a particular site:

(a) The Commission may specify, as guidance on design objectives, a lower quantity of radioactive material above background in gaseous effluents to be released to the atmosphere if it appears that the use of the design objectives described in paragraphs B. 1 and B. 2 is likely to result in an annual dose to an individual in an unrestricted area in excess of 5 millirems to the total body or 15 millirems to the skin; or

(b) Design objectives based on a higher quantity of radioactive material above background in gaseous effluents to be released to the atmosphere than the quantity specified in paragraphs B. 1 and B. 2 may be deemed to meet the requirements for keeping levels of radioactive material in gaseous effluents as low as practicable if the applicant provides reasonable assurance that the proposed higher quantity will not result in annual doses to an individual in an unrestricted area in excess of 5 millirems to the total body or 15 millirems to the skin.

C.1 The calculated annual total quantity of all radioactive iodine and radioactive material in particulate form from all light-water-cooled nuclear power reactors at a site should not result in an annual dose or dose commitment to any organ of an individual in an unrestricted area from all pathways of exposure in excess of 15 millirems. In determining the dose or dose commitment the portion thereof due to intake of radioactive material via the food pathways may be evaluated at the locations where the food pathways actually exist; and

C.2 The calculated annual total quantity of iodine-131 in gaseous effluents should not exceed 1 curie for each light-water-cooled nuclear power reactor at a site.

C.3 Notwithstanding the guidance in paragraphs $C .1$ and $C .2$ for a particular site, if an applicant for a permit to construct a light-watercooled nuclear power reactor has proposed baseline in-plant control 
measures $(a)$ to reduce the possible sources of radioactive iodine releases, and the calculated annual quantities taking into account such control measures exceed the design objective quantities set forth in paragraphs $C .1$ and $C .2$, the requirements for design objectives for radioactive jodine and radioactive material in particulate form in gaseous effluents may be deemed to have been met provided the calculated annual total quantity of all radioactive iodine and radioactive material in particulate form that may be released in gaseous effluents does not exceed four times the quantity calculated pursuant to paragraph C.1.

The numbers cited are not absolute values; rather they are intended to aid in the interpretation of the radiological protection concept of "as low as reasonably achievable."

\section{ENVIRONMENTAL PROTECTION AGENCY'S RADIATION STANDARDS (2)}

The EPA also derives its authority from the Atomic Energy Act and the National Environmental Policy Act. The division of authority between NRC and EPA is not clear-cut. EPA has promulgated standards for the uranium fuel cycle. (3) These standards are intended to provide broad protection of environment and public health. It will be NRC's responsibility to promulgate standards for specific facilities such that these standards are met. The EPA standards may be summarized as follows:

(a) The annual dose equivalent does not exceed 25 millirems to the whole body, 75 millirems to the thyroid, and 25 millirems to any other organ of any member of the public as the result of exposures to planned discharges of radioactive materials, radon and its daughters excepted, to the general environment from uranium fuel cycle operations and to radiation from these operations.

(b) The total quantity of radioactive materials entering the general environment from the entire uranium fuel cycle, per gigawatt-year of electrical energy produced by the fuel cycle, contains less than 50,000 curies of krypton-85, 5 millicuries of iodine-129, and 0.5 millicuries combined of plutonium-239 and other alpha-emitting transuranic radionuclides with half-lives greater than one year.

(a) Such in-plant control measures may include treatment of steam generator blowdown tank exhaust, clean steam supplies for turbine gland seals, condenser vacuum systems, containment purging exhaust and ventilation exhaust systems and special design features to reduce contaminated steam and liquid leakage from valves and other sources such as sumps and tanks, as appropriate for the type of reactor. 
TABLE A-1. Radionuclide Releases

For Surface Mine

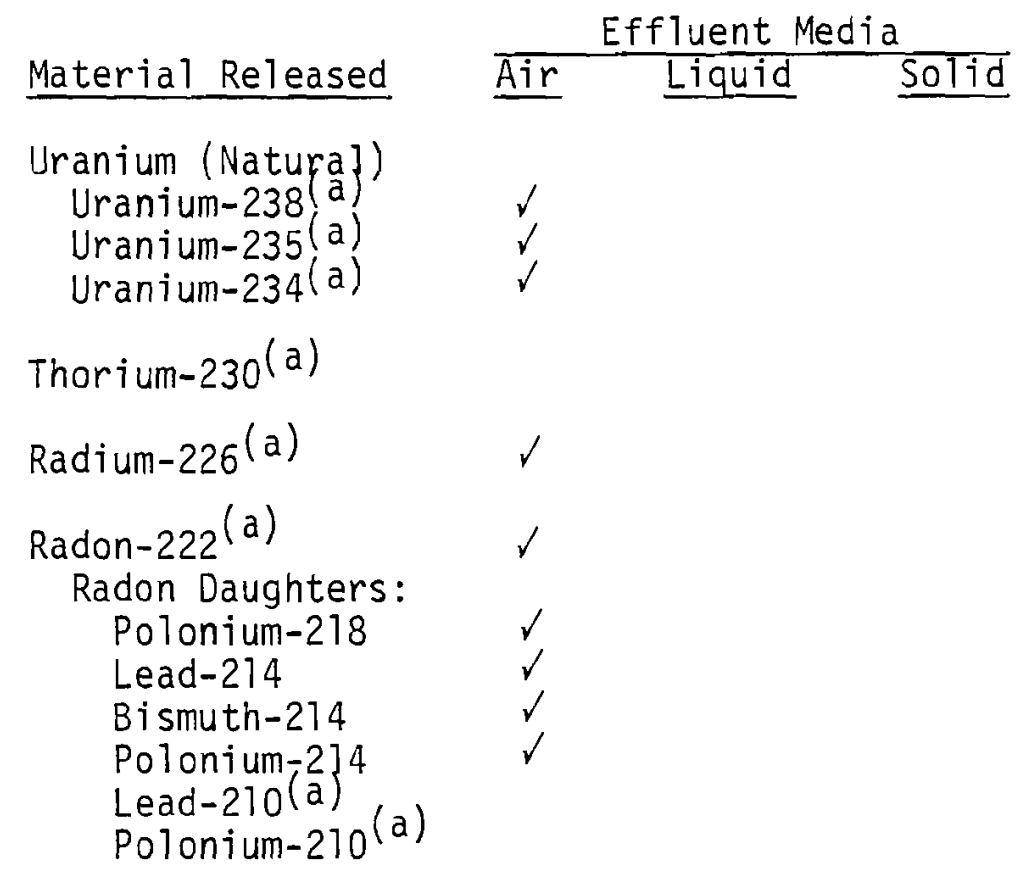

(a) Has data base in computer model 
TABLE A-2. Radionuclide Releases

For Underground Mine

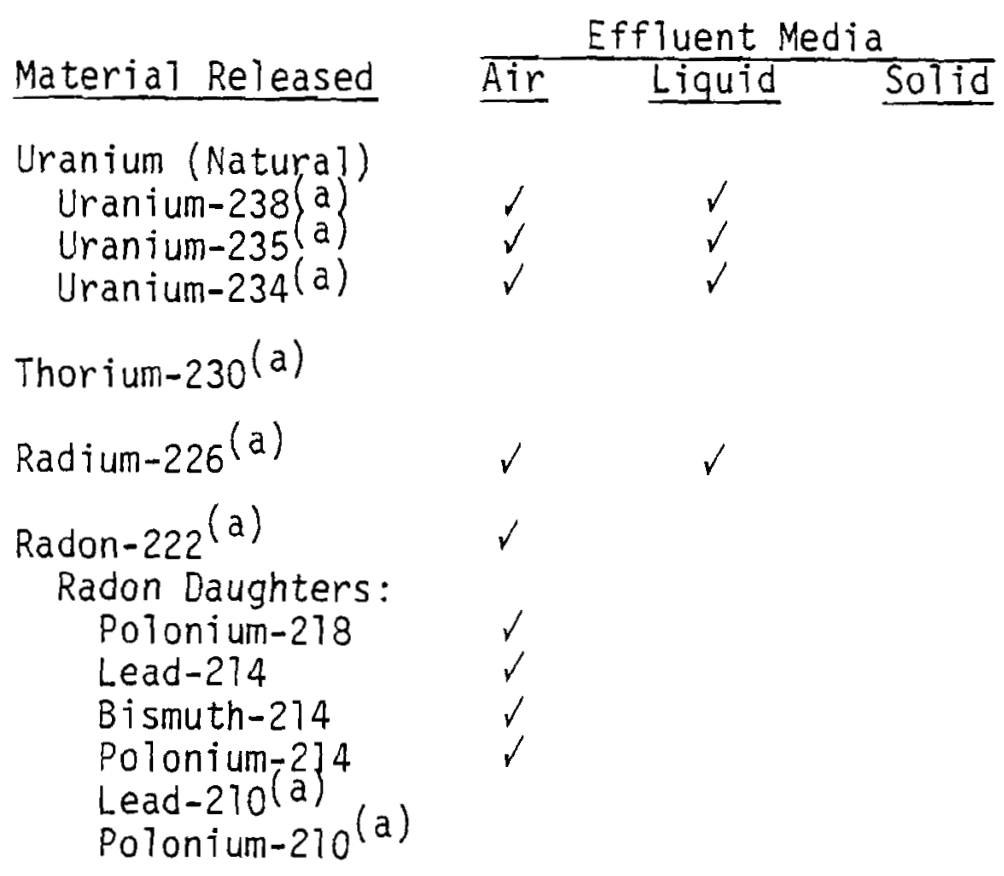

(a) Has data base in computer model 
TABLE A-3. Radionuclide Releases

For Acid Leach Mill

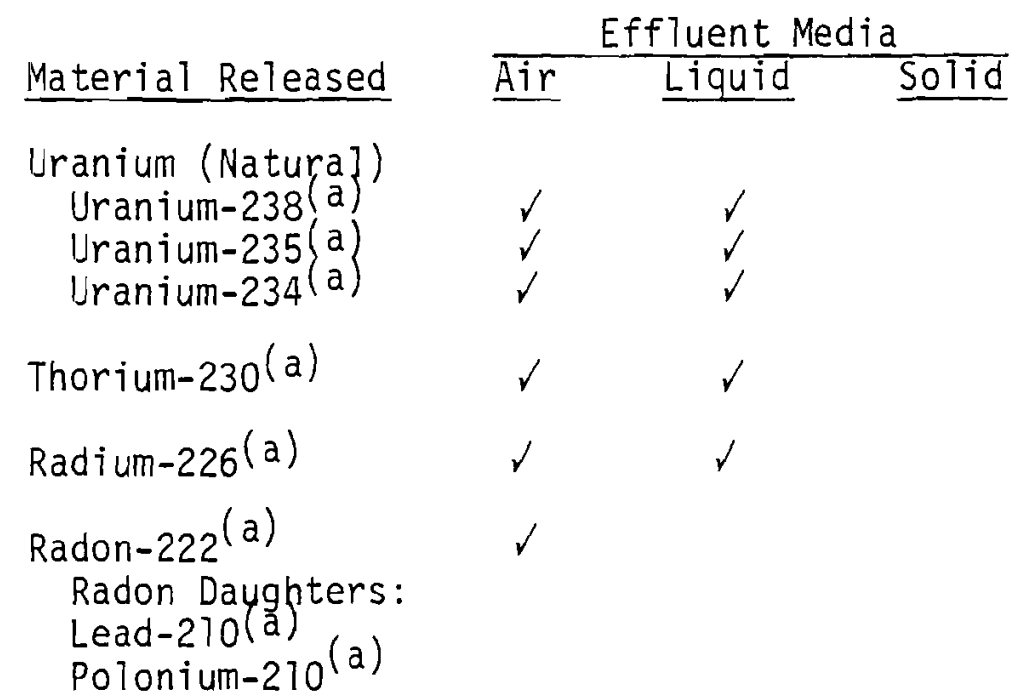

(a) Has data base in computer model 
TABLE A-4. Radionuclide Releases

For Conversion Facility

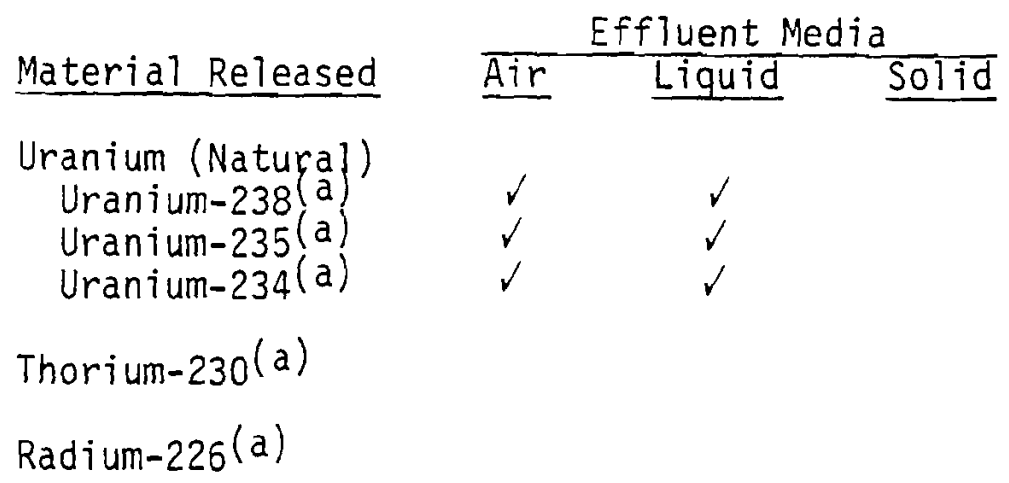

(a) Has data base in computer model 
TABLE A-5. Radionuclide Releases

For Diffusion Enrichment

\begin{tabular}{lccc} 
Material Released & & \multicolumn{2}{c}{ Effluent Media } \\
\cline { 1 - 1 } Uranium (Natural) & & Liquid & Solid \\
Uranium-238 & $\checkmark$ & $\checkmark$ \\
Uranium-235 & $\checkmark$ & $\checkmark$ \\
Uranium-234 & $\checkmark$ & $\checkmark$ \\
Thorium-234 & & $\checkmark$
\end{tabular}


TABLE A-6. Radionuclide Releases

For $\mathrm{UO}_{2}$ Fuel Fabrication

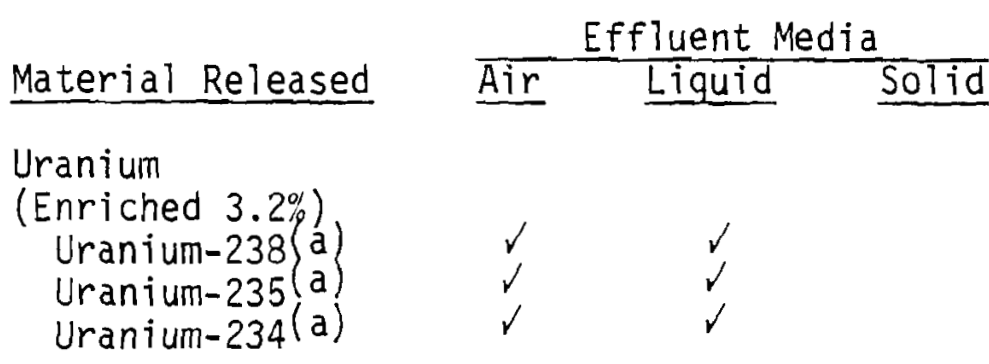

Thorium-234 (a)

Protactinium-234(a)

(a) Has data base in computer model 
TABLE A-7. Radionuclide Releases

For MOX Fuel Fabrication

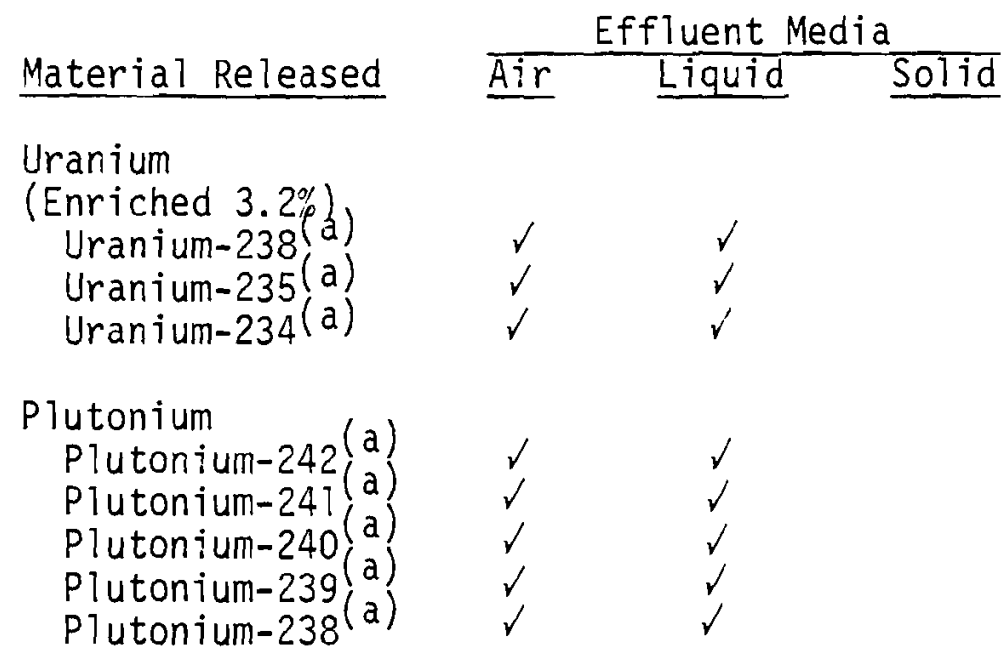

(a) Has data base in computer mode 1 
TABLE A-8. Radionuclide Releases

For PWR Reactor

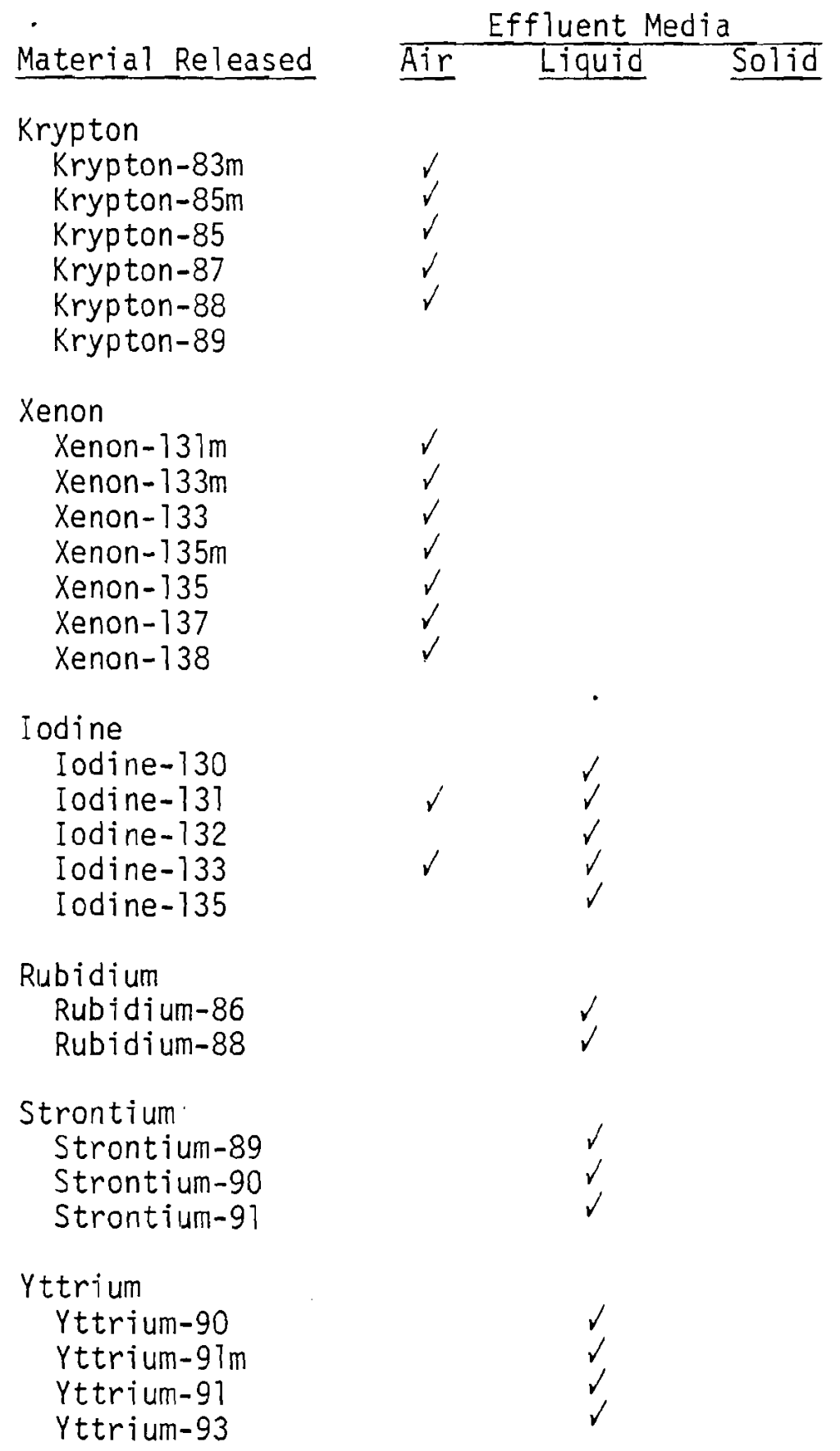


TABLE A-8. (cont)

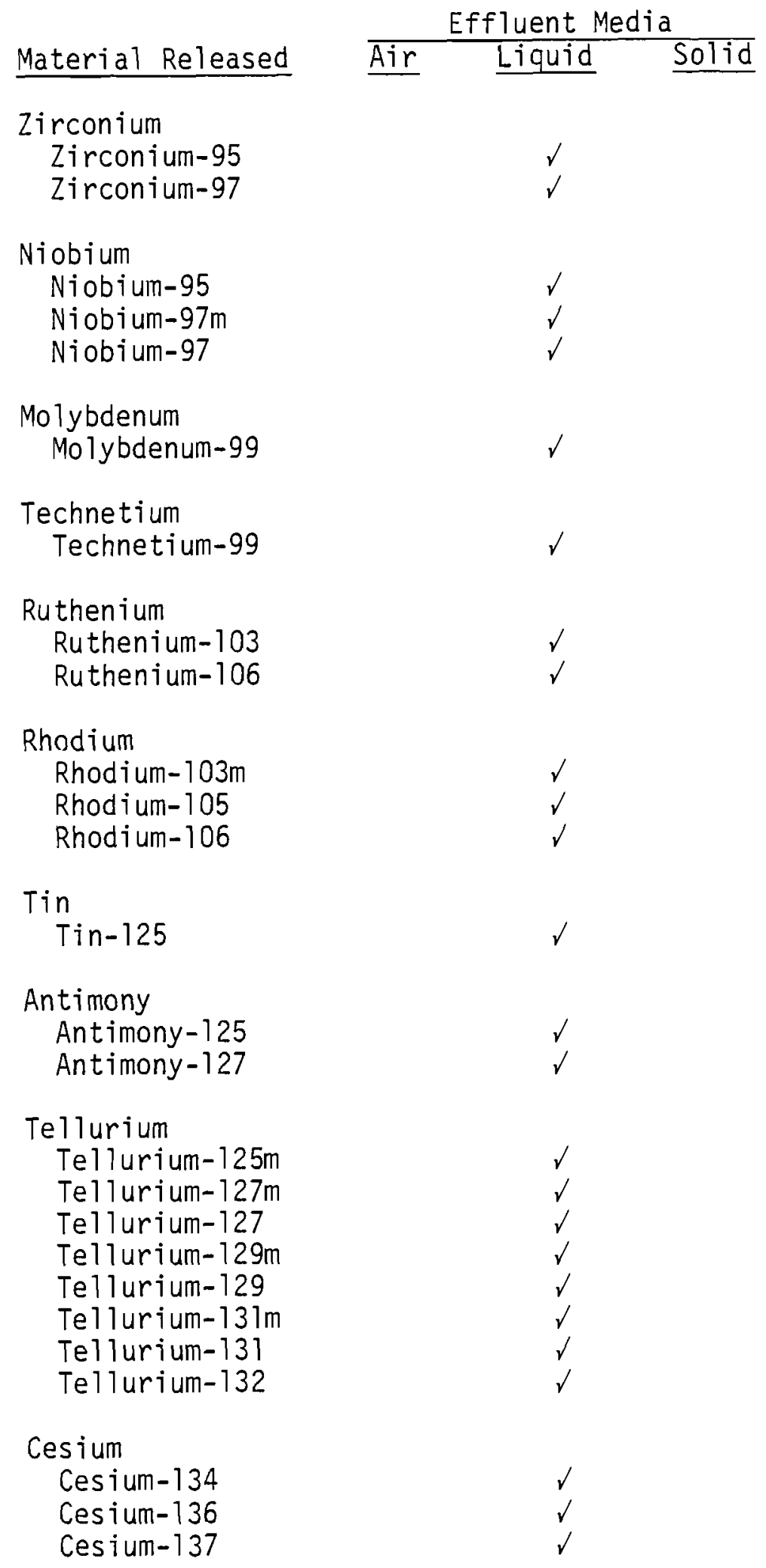


TABLE A-8. (cont)

\begin{tabular}{|c|c|c|c|}
\hline & \multicolumn{3}{|c|}{ Effluent Media } \\
\hline Material Released & Air & Liquid & Solid \\
\hline $\begin{array}{l}\text { Barium } \\
\quad \text { Barium-137m } \\
\text { Barium- } 140\end{array}$ & & $\begin{array}{l}\checkmark \\
\checkmark\end{array}$ & \\
\hline $\begin{array}{l}\text { Lanthanum } \\
\text { Lanthanum-140 }\end{array}$ & & $\checkmark$ & \\
\hline $\begin{array}{l}\text { Cerium } \\
\quad \text { Cerium-141 } \\
\text { Cerium-143 } \\
\text { Cerium-144 }\end{array}$ & & $\begin{array}{l}d \\
y \\
y \\
y\end{array}$ & \\
\hline $\begin{array}{l}\text { Praseodymi um } \\
\text { Praseodymi um-143 } \\
\text { Praseodymi um-144 }\end{array}$ & & 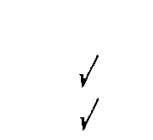 & \\
\hline $\begin{array}{l}\text { Neodymi um } \\
\text { Neodymium- } 147\end{array}$ & & $\checkmark$ & \\
\hline $\begin{array}{l}\text { Promethium } \\
\text { Promethium-147 }\end{array}$ & & $\checkmark$ & \\
\hline $\begin{array}{l}\text { Chromi um } \\
\quad \text { Chromi um-51 }\end{array}$ & & $\checkmark$ & \\
\hline $\begin{array}{l}\text { Manganese } \\
\text { Manganese-54 }\end{array}$ & & $\checkmark$ & \\
\hline $\begin{array}{l}\text { Iron } \\
\text { Iron-55 } \\
\text { Iron-59 }\end{array}$ & & $\gamma$ & \\
\hline $\begin{array}{l}\text { Cobalt } \\
\text { Cobalt }-58 \\
\text { Cobalt }-60\end{array}$ & & $\gamma$ & \\
\hline Tritium & & $\checkmark$ & \\
\hline
\end{tabular}


TABLE A-9. Radionuclide Releases

For BWR Reactor

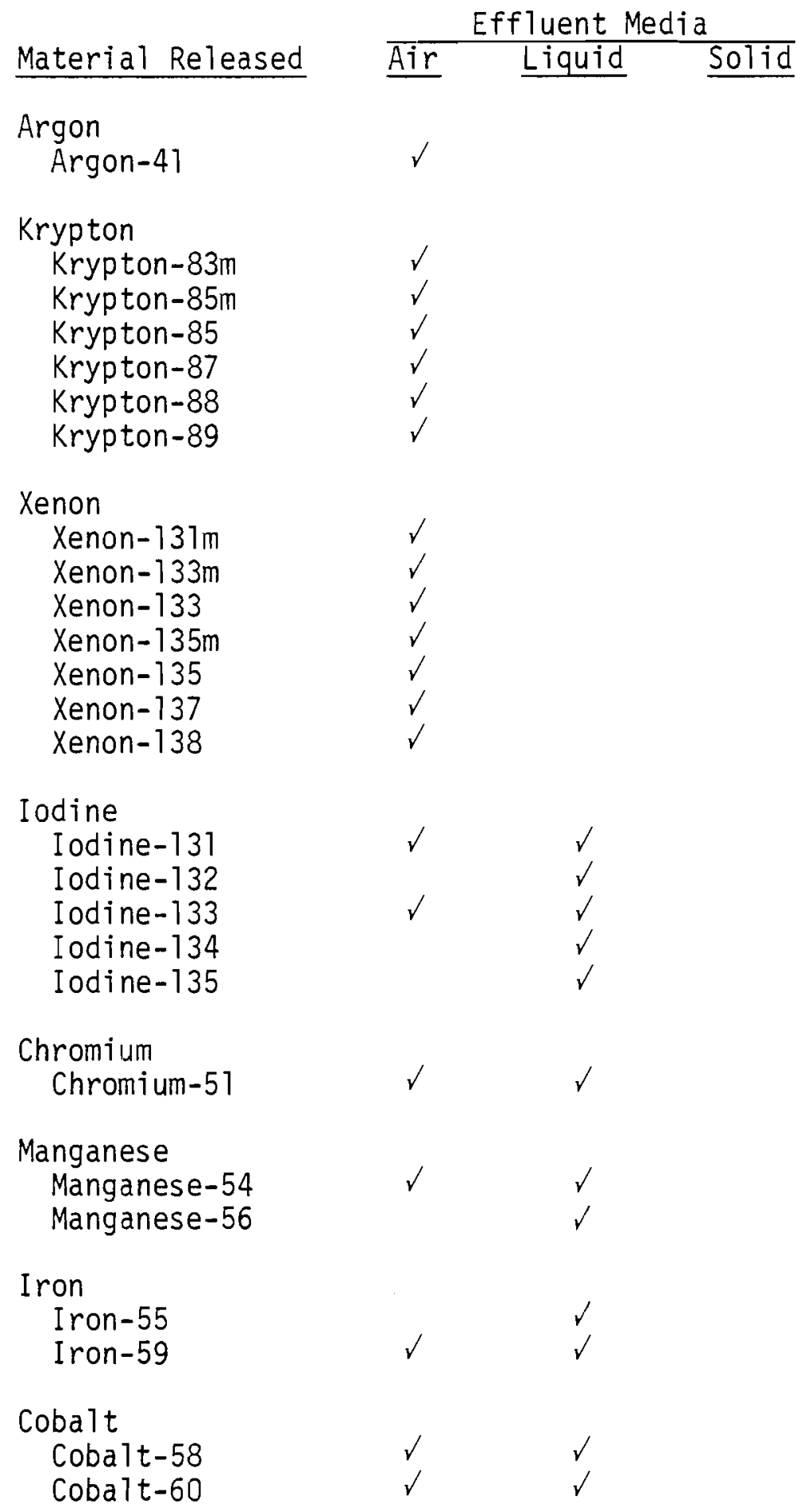


TABLE A-9. (cont)

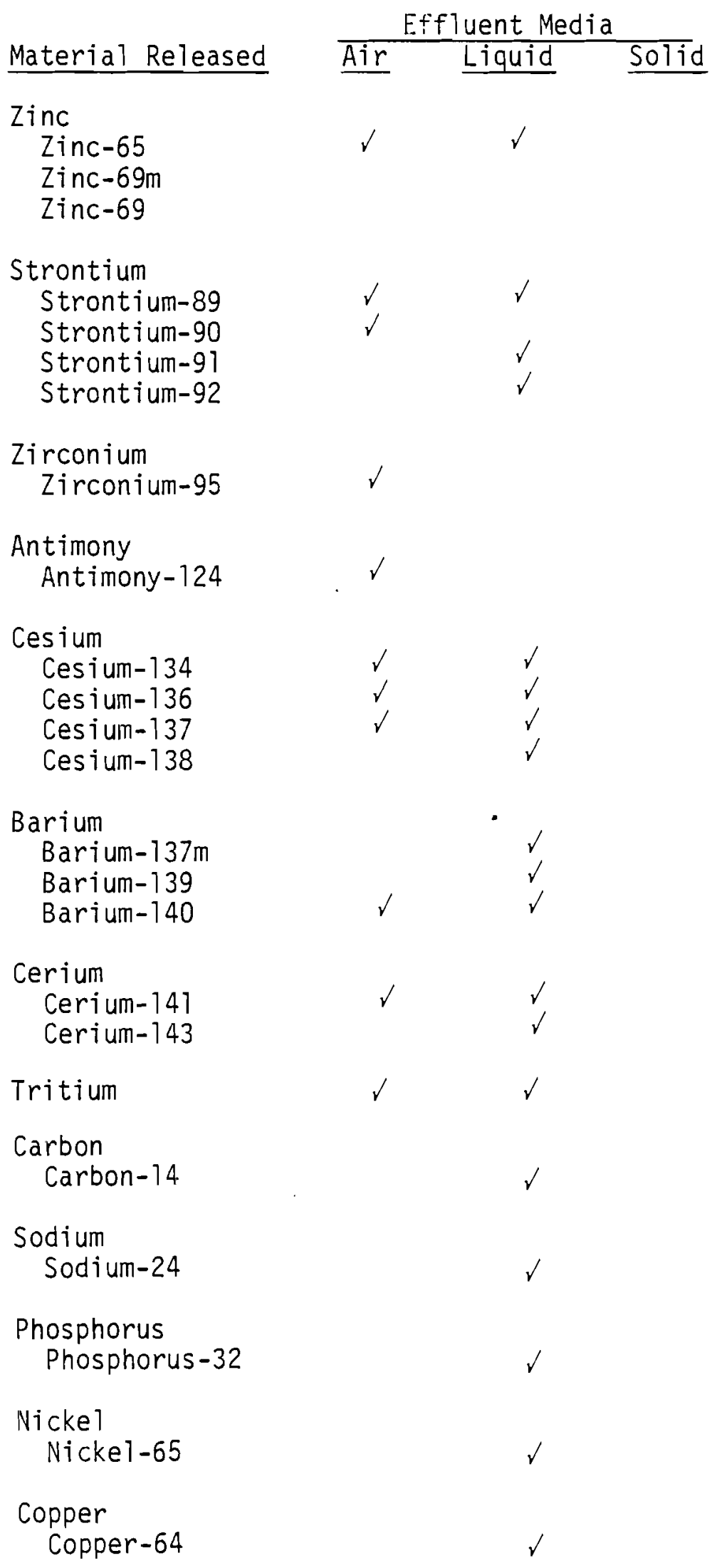


TABLE A-9. (cont)

\begin{tabular}{|c|c|c|c|}
\hline & & fluent $M$ & \\
\hline Material Released & $\underline{\underline{\text { Air }}}$ & Liquid & Solid \\
\hline $\begin{array}{l}\text { Wol fram } \\
\text { Wol fram-187 }\end{array}$ & & $\checkmark$ & \\
\hline $\begin{array}{l}\text { Neptunium } \\
\text { Neptunium-239 }\end{array}$ & & $\checkmark$ & \\
\hline $\begin{array}{l}\text { Bromine } \\
\text { Bromine-83 } \\
\text { Bromine-84 }\end{array}$ & & $\checkmark$ & \\
\hline $\begin{array}{l}\text { Rubidium } \\
\quad \text { Rubidium-89 }\end{array}$ & & $\checkmark$ & \\
\hline $\begin{array}{l}\text { Yttrium } \\
\text { Yttrium-91m } \\
\text { yttrium-91 } \\
\text { yttrium-92 } \\
\text { Yttrium-93 }\end{array}$ & & $\begin{array}{l}\checkmark \\
\checkmark \\
\checkmark \\
\checkmark\end{array}$ & \\
\hline $\begin{array}{l}\text { Niobium } \\
\quad \text { Niobium-98 }\end{array}$ & & $\sqrt{ }$ & \\
\hline $\begin{array}{l}\text { Molybdenum } \\
\text { Molybdenum-99 }\end{array}$ & & $\checkmark$ & \\
\hline $\begin{array}{l}\text { Technetium } \\
\text { Technetium-99m } \\
\text { Technetium-102 } \\
\text { Technetium-104 }\end{array}$ & & $\begin{array}{l}v \\
v \\
v\end{array}$ & \\
\hline $\begin{array}{l}\text { Ruthenium } \\
\text { Ruthenium-103 } \\
\text { Ruthenium-105 }\end{array}$ & & $\checkmark$ & \\
\hline $\begin{array}{l}\text { Rhodium } \\
\quad \text { Rhodium- } 103 \mathrm{~m} \\
\text { Rhodium- } 105 \mathrm{~m} \\
\text { Rhodium- } 105\end{array}$ & & $\begin{array}{l}\checkmark \\
v \\
v\end{array}$ & \\
\hline $\begin{array}{l}\text { Tellurium } \\
\text { Tellurium-129m } \\
\text { Tellurium-129 } \\
\text { Tel lurium- } 131 \mathrm{~m}\end{array}$ & & $\begin{array}{l}\checkmark \\
\checkmark \\
v\end{array}$ & \\
\hline
\end{tabular}


TABLE A-9. (cont)

\begin{tabular}{lccc} 
Material Released & & Effluent Media \\
\cline { 3 - 3 } Tellurium-131 & & $\frac{\text { Liquid }}{\text { Solid }}$ \\
Tellurium-132 & & $\checkmark$ \\
Lanthanum & $\checkmark$ \\
Lanthanum-140 & & $\checkmark$ \\
Lanthanum-141 & & $\checkmark$ \\
Lanthanum-142 & & $\checkmark$ \\
Praseodymium & & \\
Praseodymium-143 & $\checkmark$
\end{tabular}


TABLE A-10. Radionuclide Releases

For Reprocessing

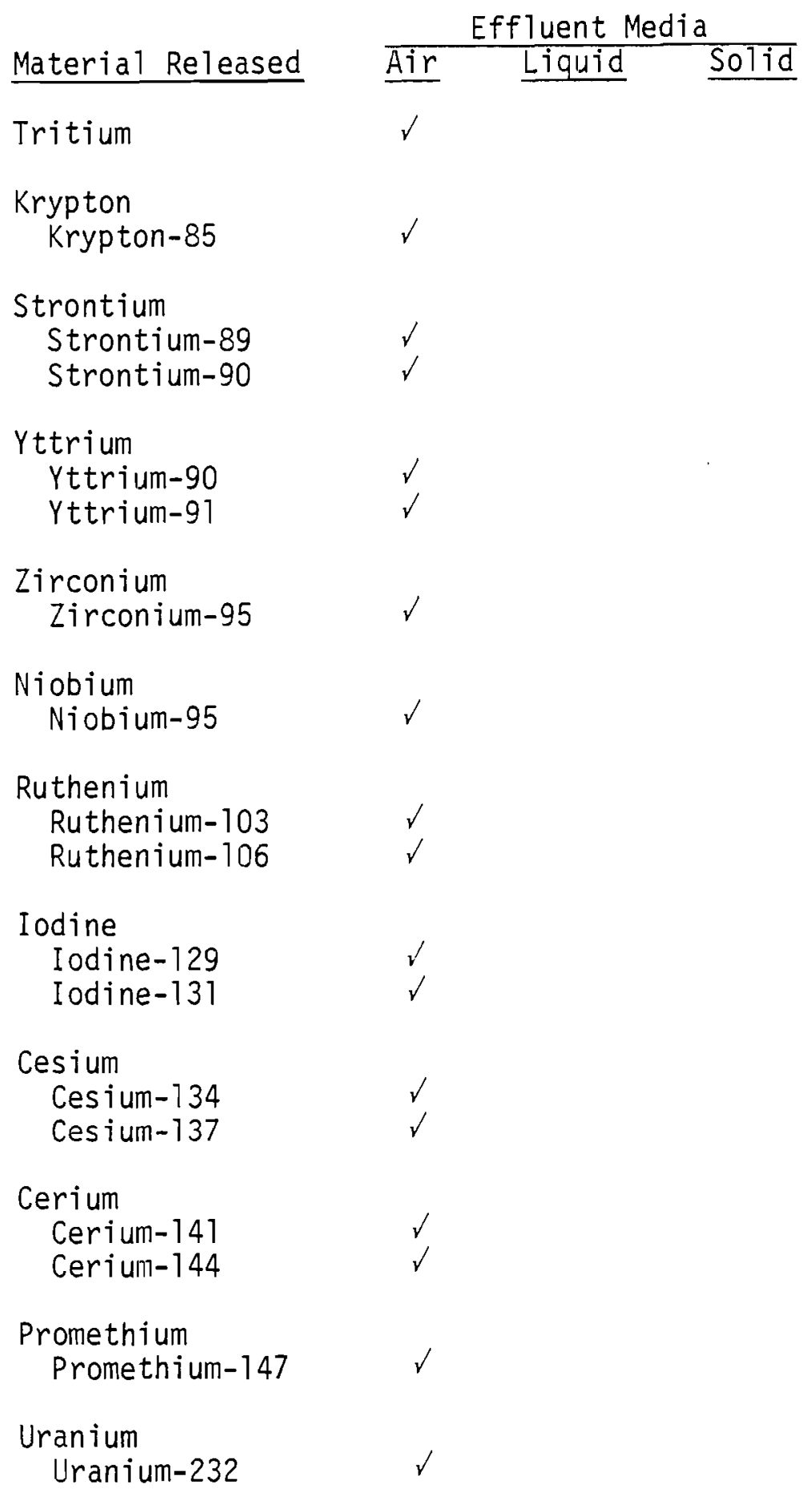


TABLE A-10. (cont)

\begin{tabular}{lccc} 
Material Released & & \multicolumn{2}{c}{ Effluent Media } \\
\cline { 1 - 2 } Uranium-233 & & $\checkmark$ \\
Uranium-234 & & $\checkmark$ \\
Uranium-235 & & $\checkmark$ \\
Uranium-236 & & $\checkmark$ \\
Uranium-237 & $\checkmark$ \\
Uranium-238 & $\checkmark$ \\
Plutonium & \\
Plutonium-238 & $\checkmark$ \\
Plutonium-239 & $\checkmark$ \\
Plutonium-240 & $\checkmark$ \\
Plutonium-241 & $\checkmark$ \\
Plutonium-242 & \\
Americium & \\
Americium-241 & $\checkmark$ \\
Americium-242 & $\checkmark$ \\
Curium & \\
Curium-242 & $\checkmark$ \\
Curium-243 & $\checkmark$ \\
Curium-244 & $\checkmark$
\end{tabular}




\section{REFERENCES}

1. Code of Federal Regulations, Title 10-Energy, Part 20, Standards for Protection Against Radiation, U.S. Government Printing Office, Washington, DC, 1977.

2. Code of Federal Regulations, Title 10-Energy, Part 50, Licensing of Production and Utilization Facilities, Appendix I, Numerical Guide for Design Objectives and Limiting Conditions for Operation to Meet the Criterion "As Low as Practicable" for Radioactive Material in Light-WaterCooled Nuclear Power Reactor Effluents, U.S. Government Printing Office, Washington, DC, 1976.

3. "Environment Radiation Protection Standards for Nuclear Power Operations," Federal Register, Vol. 42, No.9, Thursday, January 13, 1977. 
-

$+$

, 


\section{APPENDIX B}

ENVIRONMENTAL STANDARDS FOR GASEOUS CHEMICAL EFFLUENTS 

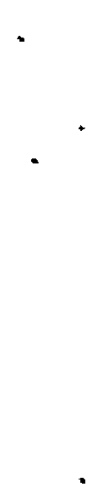
APPENDIX B

\section{ENVIRONMENTAL STANDARDS FOR GASEOUS CHEMICAL EFFLUENTS}

This appendix is a compilation of existing environmental standards which may be used to assess the present and future needs for control of gaseous chemical effluents from the nuclear fuel cycle. Three types of standards are useful in such an assessment: (1) effluent standards, (2) ambient air quality standards, and (3) toxicological standards. These standards provide the bases for deciding if a particular chemical effluent must be controlled or if a process must be changed. These are all federal standards.

STANDARDS OF PERFORMANCE FOR NEW STATIONARY SOURCES OF AIR POLLUTION

In accordance with powers embodied in the Clean Air Act of 1970, the EPA has promulgated performance standards for many industrial sources of air pollution. The standards apply to new, modified and reconstructed stationary sources. The first standards were promulgated in December 1971 and reported in the Federal Register. (1) Since then there have been many changes and additions. Table B-1 lists these categories of stationary sources and the affected facilities to which the standards apply. The table also lists the specific Federal Register citations, which refer to the volume and page number in the Federal Register. For example, 36 FR 24876 means Volume 36, page number 24876 .

EMISSION STANDARDS FOR HAZARDOUS POLLUTANTS

To date, four species--mercury, beryllium, asbestos, and vinyl chloride-have been classified by the EPA as hazardous pollutants. (2) Emission (effluent) standards for these species from certain sources have been set and are shown in Table B-2. 


\section{TABLE B-1. Federal Standards of Performance for New Stationary Sources of Air Pollution}

\begin{tabular}{l}
\multicolumn{1}{c}{ Source Category } \\
STEAM GENERATORS \\
$(>250 \mathrm{mil1i}$ B Btu/hr) \\
Promulgated \\
$12 / 23 / 71$ (36 FR 24876) \\
Revised \\
$7 / 26 / 72$ ( 37 FR 14877) \\
$5 / 14 / 74$ (39 FR 20790) \\
$1 / 16 / 75$ (40 FR 2803) \\
$10 / 6 / 75$ (40 FR 46250) \\
$11 / 22 / 76$ (41 FR 51397)
\end{tabular}

INCINERATORS

( $>50$ tons/day)

Promulgated

12/23/71 (36 FR 24876)

Revised

6/14/74 (39 FR 20790)

PORTLAND CEMENT PLANTS

Promulgated

$12 / 23 / 71$ (36 FR 24876)

Revised

6/14/74 (39 FR 20790)

$11 / 12 / 74$ (39FR 39874)

$10 / 6 / 75$ (40 FR 46250)

NITRIC ACID PLANTS

Promulgated

12/23/71 (36 FR 24876)

Revised

$5 / 23 / 73$ (38 FR 13562)

$6 / 14 / 74$ (39 FR 20790)

10/6/75 (40 FR 46250)

SULFURIC ACID PLANTS

Promulgated

12/23/71 (36 FR 24876)

Revised

$5 / 23 / 73$ (38 FR 13562)

$6 / 14 / 74$ (39 FR 20790)

10/6/75 (40 FR 46250)

ASPHALT CONCRETE PLANTS

Promulgated

$3 / 3 / 74$ (39 FR 9308)

Revised

10/6/75 (40 FR 46250)

PETROLEUM REFINERIES

Promulgated

3/8/74 (39 FR 9308)

Revised

10/6/75 (40 FR 76250)
Affected Facility

Coal-fired Boilers

0il-Fired Boilers

Gas-Fired Boilers

Incinerators

Kiln

Clinker Cooler

Fugitive

Emission Points

Process Equipment

Opacity

No $x$

Pollutant

Particulate

Opacity

$\mathrm{NO}_{\mathrm{X}}^{2}$

(except lignite

and coal

refuse)

Particulate

Opacity

$\mathrm{NO}^{2}$

Particulate

Opacity

NO $x$

Particulate

Particulate Opacity

Particulate Opacity

Opacity

Process Equipment

$\mathrm{SO}_{2}$

Acid Mist

Jpacity

Particulate

Opacity

and weighing

Systems; Storage,

Iransfer, and Load-

ing Systems; and

Dust Handling

Equipment

Catalytic Cracker

Fuel Gas

Combination
Particulate Opacity CO

$\mathrm{SO}_{2}$
Emission Level

\section{$0.10 \mathrm{Ib} / 10^{6} \mathrm{Btu}$}

$1.216 / 10^{20 \%}$ Btu

$0.701 \mathrm{~b} / 10^{6 \mathrm{Btu}} \mathrm{Btu}$

$0.101 \mathrm{~b} / 10^{6} \mathrm{Btu}$ $20 \% ; 40 \% 2 \mathrm{~min} / \mathrm{hr}$ $0.80 \mathrm{lb} / 106 \mathrm{Btu}$ $0.30 \mathrm{lb} / 10^{6} \mathrm{Btu}$

$0.101 \mathrm{~b} / 10^{6} \mathrm{Btu}$

$0.2010 / 10^{6}$ Btu

$0.80 \mathrm{gr} / \mathrm{dscf}(\mathrm{a})$ corrected to $12 \% \mathrm{CO}$

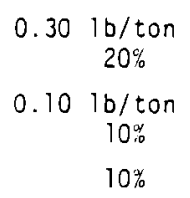

$3.010 /$ $3.0 \mathrm{lb} /$ ton
$4.01 \mathrm{~b} /$ ton $0.15 \mathrm{lb} / \mathrm{ton}$ $10^{\circ \%}$

$$
\begin{gathered}
0.04 \mathrm{gr} / \mathrm{dscf} \\
(90 \mathrm{ig} / \mathrm{dscm}) \\
20 \%
\end{gathered}
$$

(a) Grains per dry standard cubic foot of gas.

(b) Milligrams per dry standard cubic meter of gas. 
TABLE B-1. (cont)

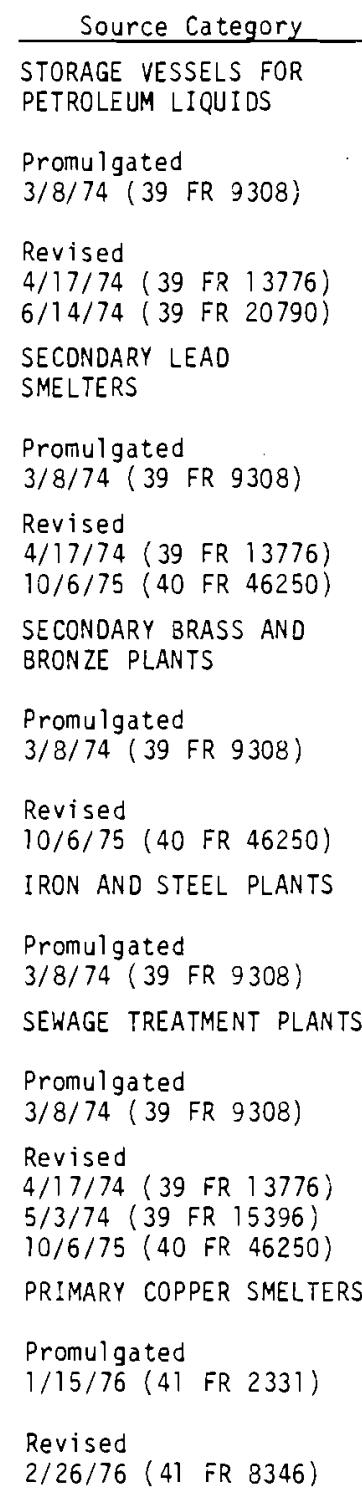

PRIMARY ZINC SMELTERS

Promulgated

$1 / 15 / 76$ (41 FR 2331)

PRIMARY LEAD SMELTERS

Promulgated

$1 / 15 / 76$ (41 FR 2331)

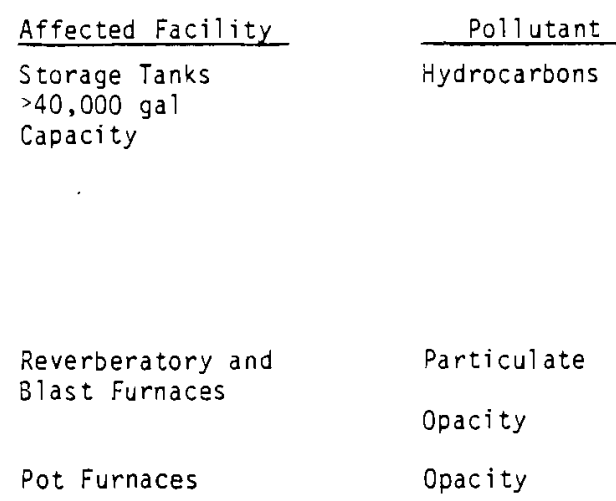

Pollutant

Hydrocarbons

Particulate

opacity

Opacity

Dryer

Roaster, Smelting Furnace, Copper Converter (Reverberatory Furnaces that Process HighImpurity Feed Materials are Exempt from $\mathrm{SO}_{2}$ Standard)

Sintering Machine

Roaster

Blast or Reverberatory Furnace, Sintering Machine Discharge End

Sintering Machine, Electric Smelting Furnace, Converter
Particulate

Opacity

Opacity

Particulate

Particulate

Opacity

Particulate

Opacity

$\mathrm{SO}_{2}$

Opacity

Particulate

Opacity

$\mathrm{SO}_{2}$

Opacity

Particulate

Opacity

$\mathrm{SO}_{2}$

opacity
Emission Level

For Vapor Pressure 78-570 mm $\mathrm{Hg}$, Equip with Floating Roof, Vapor Recovery System, or Equivalent; for Vapor Pressure $>570 \mathrm{~mm}$ $\mathrm{Hg}$, Equip with Vapor Recovery System or Equivalent

$0.022 \mathrm{gr} / \mathrm{dscf}$ $(50 \mathrm{mg} / \mathrm{dscm}$ ) $20 \%$

$10 \%$

$$
\begin{gathered}
0.022 \mathrm{gr} / \mathrm{dscf} \\
(50 \mathrm{mg} / \mathrm{dscm}) \\
20 \% \\
10 \%
\end{gathered}
$$

$0.022 \mathrm{gr} / \mathrm{dscf}$ (50 $\mathrm{mg} / \mathrm{dscm}$ )

$1.301 \mathrm{~b} /$ ton $20 \%$
$0.022 \mathrm{gr} / \mathrm{ds} c f$
$(50 \mathrm{mg} / \mathrm{dscr})$
$20 \%$
$0.065 \%$
$20 \%$

$0.022 \mathrm{gr} / \mathrm{dscf}$ ( $50 \mathrm{mg} / \mathrm{dscm}$ )

$0.065 \%$ $20 \%$

$0.022 \mathrm{gr} / \mathrm{dscf}$ $(50 \mathrm{mg} / \mathrm{ds} \mathrm{cm}$ )

$0.065 \%$ $20 \%$ 


\section{TABLE B-1. (cont)}

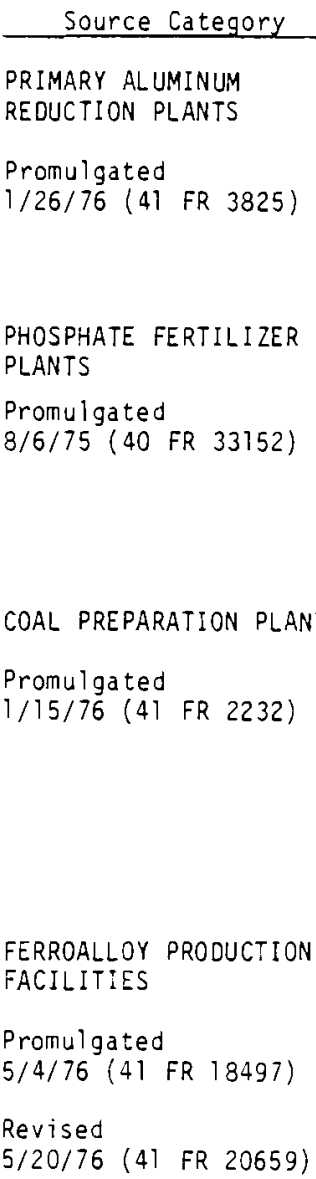

Affected Facility

Potroom Group

(a) Soderberg Plant

(b) Prebake Plant

Anode Bake Plants

Wet Process

Phosphoric Acid

Superphosphoric Acid

Diammonium Phosphate

Triple Superphosphate

Granular Triple

Superphosphate

Thermal Dryer

Pneumatic Coal

Cleaning Equipment

Processing Conveying

Equi pment, Storage

Systems, Transfer and

Loading Sys tems

Electric Submerged Arc Furnaces

Pollutant
$\begin{aligned} & \text { (a) Total } \\ & \text { Fluorides } \\ & \text { Opacity }\end{aligned}$
(b) Total
Fluorides
Opacity
Total Fluorides
Opacity
Total Fluorides
Total Fluorides
Total Fluorides
Total Fluorides
Total Fluorides
Particulate
Opacity
Particulate
Opacity
Opacity

Dust Hand 1 ing

Equi pment

Electric Arc

Promulgated

9/23/75 (40 FR 43850)
Furnaces

$\begin{array}{ll} & \text { Opacity } \\ & \text { (a) Control } \\ & \text { (b) Device } \\ & \\ \text { Dust Handing Roof } \\ \text { Equipment }\end{array}$

Particulate

Opacity

co

Emission Level

$$
\begin{gathered}
2.0 \begin{array}{c}
1 \mathrm{~b} / \text { ton } \\
10 \%
\end{array} \\
1.91 \mathrm{~b} / \text { ton } \\
10 \% \\
0.1 \begin{array}{c}
1 \mathrm{~b} / \text { ton } \\
20 \%
\end{array} \\
0.021 \mathrm{~b} / \text { ton } \\
0.011 \mathrm{~b} / \text { ton } \\
0.061 \mathrm{~b} / \text { ton } \\
0.21 \mathrm{~b} / \text { ton } \\
5.0 \times 10^{-4} \\
1 \mathrm{~b} / \mathrm{hr} / \text { ton } \\
0.031 \mathrm{gr} / \mathrm{dscf}(\mathrm{c}) \\
(0.070 \mathrm{~g} / \mathrm{dscm}) \\
20 \\
0.018 \mathrm{gr} / \mathrm{dscf} \\
(0.040 \mathrm{~g} / \mathrm{dscm}) \\
10 \% \\
20 \%
\end{gathered}
$$

Particulate
Opacity
Co
Opacity
Particulate
Opacity
(a) Control
Device
(b) Shop Roof
Opacity

(c) Grams per dry standard cubic meter of gas. 
TABLE B-2. Emission Standards for Hazardous Air Pollutants

\begin{tabular}{l}
\multicolumn{1}{c}{ Source Category } \\
\hline MERCURY PROCESSING \\
Promul gated \\
$4 / 6 / 73$ (38 FR 8820) \\
Revised \\
10/14/75 (40 FR 48292) \\
BERYLLIUM PROCESSING \\
AND USE \\
Promul gated \\
4/6/73 (38 FR 8820)
\end{tabular}

ASBESTOR PROCESSING AND USE

Promulgated

$4 / 6 / 73$ (38 FR 8820)

Revised

$5 / 3 / 74$ (39 FR 15936) $10 / 14 / 75$

(40 FR 48292)

Affected Facility
Mercury ore process-
ing facilities, or
mercury cell chlor-
alkali plants

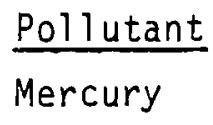

Emission Leve1/ Limitation

Not more than $2300 \mathrm{gm} /$ day for entire facility

Extraction plants, foundries, ceramic manufacturing plants beryllium waste disposal incinerators, propellant plants, machine shops, processing alloys with $>5 \%$ beryllium.

Rocket testing facilities

Asbestos mills, manufacturing operations

Spraying of asbestos fireproofing and insulation that contains more than $1 \%$ asbestos on buildings, structures, pipes and conduits

Spraying of asbestos fireproofing and insulation that contains more than $1 \%$ asbestos on equipment and machinery

Use of asbestos mill tailings on roadways

Demolition operations
Beryllium Not more than $10 \mathrm{gm} /$ day (option of meeting ambient level of 0.01 $\mathrm{\mu g} / \mathrm{m}^{3}$ if $3 \mathrm{yr}$ of ambient data available)

Beryllium

Limited to $75 \mathrm{ugm}-\mathrm{min} / \mathrm{m}^{3}$

Asbestos No visible emissions or use control equipment meeting specific performance characteristics

Asbestos Banned

Asbes tos

No visible emissions

Asbestos

Banned except on asbestos ore deposits

Asbestos

Good control practices 
TABLE B-2. (cont)

\begin{tabular}{|c|c|c|c|}
\hline Source Category & Affected Facility & Pollutant & $\begin{array}{c}\text { Emission Level/ } \\
\text { Limitation }\end{array}$ \\
\hline $\begin{array}{l}\text { PRODUCTION OF } \\
\text { PLASTICS }\end{array}$ & $\begin{array}{l}\text { Ethylene dichloride } \\
\text { plant }\end{array}$ & $\begin{array}{l}\text { Vinyl } \\
\text { chloride }\end{array}$ & $\begin{array}{l}\text { a) Less than } 10 \\
\text { ppm for di- }\end{array}$ \\
\hline \multirow[t]{4}{*}{$\begin{array}{l}\text { Promulgated } \\
10 / 21 / 76 \\
\text { (41 FR 46559) }\end{array}$} & & & $\begin{array}{l}\text { chloride puri- } \\
\text { fication process } \\
\text { b) Less than } 0.2 \\
\text { g/kg of ethy- } \\
\text { lene dichloride } \\
\text { product }\end{array}$ \\
\hline & $\begin{array}{l}\text { Vinyl chloride } \\
\text { plant }\end{array}$ & $\begin{array}{l}\text { Vinyl } \\
\text { chloride }\end{array}$ & $\begin{array}{l}\text { Less than } 10 \mathrm{ppm} \\
\text { from vinyl chloride } \\
\text { formation and puri- } \\
\text { fication process }\end{array}$ \\
\hline & $\begin{array}{l}\text { Polyvinyl } \\
\text { chloride plant }\end{array}$ & $\begin{array}{l}\text { Vinyl } \\
\text { chloride }\end{array}$ & $\begin{array}{l}\text { a) Less than } 10 \mathrm{ppm} \\
\text { from reactor } \\
\text { b) Less than } 0.02 \\
\text { g/kg of product } \\
\text { during reactor } \\
\text { opening } \\
\text { c) Restrictions on } \\
\text { operation pro- } \\
\text { cedures to } 1 \text { imit } \\
\text { fugitive emis- } \\
\text { sions }\end{array}$ \\
\hline & $\begin{array}{l}\text { Ethylene dichloride } \\
\text { plant plus vinyl } \\
\text { chloride plant or } \\
\text { polyvinyl chloride } \\
\text { plant }\end{array}$ & $\begin{array}{l}\text { Vinyl } \\
\text { chloride }\end{array}$ & $\begin{array}{l}\text { a) Less than } 10 \mathrm{ppm} \\
\text { in vent gas } \\
\text { b) Strict regula- } \\
\text { tion regarding } \\
\text { relief discharge } \\
\text { valves, pumps } \\
\text { and other fugi- } \\
\text { tive emissions }\end{array}$ \\
\hline
\end{tabular}




\section{AMBIENT AIR QUALITY STANDARDS}

The Clean Air Act of 1970 required the EPA to set ambient air quality standards. (3) They established two types of ambient standards. Primary standards are levels of air quality necessary to protect human health. Secondary standards are levels desired to protect the state of human welfare, i.e., agricultural crops, materials, property, animals, and aesthetic factors. Table B-3 lists the current ambient air quality standards. These standards are being used by local, state and federal government to develop air pollution control strategies and implementation plans. 01d and new sources of air pollution must be controlled such that these standards are met. In areas where the air quality is better than these standards, the air quality may not be degraded any further.

\section{TOXICOLOGICAL STANDARDS}

Threshold limit values (TLV) are airborne concentrations of substances that nearly all workers may be repeatedly exposed to without adverse effect. It is a time-weighted average in that it refers to a concentration for a norma 1 8-hr work day or 40-hr work week. TLVs are set by the American Conference of Governmental Industrial Hygienists (ACGIH). (4) In May 1971, TLVs gained legal status when the Occupational Safety and Health Administration (OSHA) adopted the Threshold Limit Values for 1968 as the official federal standards for industrial air. Table B-4 provides a partial listing of the current TLVs adopted by ACGIH.

ENVIRONMENTAL STANDARDS FOR CHEMICAL EFFLUENTS FROM NUCLEAR FUEL CYCLE FACILITIES

The nuclear fuel cycle facility documents have been studied and a tentative list of gaseous effluents identified. The facilities studied include:

- Surface Mining

- Underground Mining

- Acid Leach Mill

- Aqueous Conversion Plant

- Gaseous Diffusion Enrichment Plant 
TABLE B-3. National Ambient Air Quality Standards(a)

\begin{tabular}{|c|c|c|c|}
\hline \multirow{2}{*}{ Species } & \multirow{2}{*}{$\begin{array}{c}\text { Averaging } \\
\text { Period } \\
\end{array}$} & \multicolumn{2}{|c|}{ Air Quality Standards (b) } \\
\hline & & Primary & Secondary \\
\hline \multirow{3}{*}{$\mathrm{SO}_{x}\left(\right.$ as $\left.\mathrm{SO}_{2}\right)$} & $\operatorname{AAM}(c)$ & $80(0.03)$ & $60(0.02)$ \\
\hline & 24 & $365(0.14), 1 x$ & $260(0.09), 1 x$ \\
\hline & 3 & -- & $1300(0.49), 1 x$ \\
\hline \multirow[t]{2}{*}{ Particulate } & $\operatorname{AGM}(c)$ & 75 & 60 \\
\hline & 24 & $260,1 x$ & $150,1 x$ \\
\hline \multirow[t]{2}{*}{ Carbon monoxide } & 8 & $10,000(9), 1 x$ & $10,000(9), 1 x$ \\
\hline & 1 & $40,000(35), 1 x$ & $40,000(35), 1 x$ \\
\hline Oxidant $\left(\right.$ as $\left.0_{3}\right)$ & 1 & $160(0.08), 1 x$ & $160(0.08), 1 x$ \\
\hline $\mathrm{NO}_{x}\left(\right.$ as $\left.\mathrm{NO}_{2}\right)$ & $\operatorname{AAM}(c)$ & $100(0.05)$ & $100(0.05)$ \\
\hline $\begin{array}{l}\text { Hydrocarbons ( } \mathrm{HC}) \\
\left(\text { as } \mathrm{CH}_{4}\right)\end{array}$ & 3 & $160(0.24), 1 x$ & $160(0.24), 1 x$ \\
\hline
\end{tabular}

(a) "National Primary and Secondary Ambient Air Quality Standards", 36 FR 22384.

(b) Format for each entry is as follows: STANDARD $\mu \mathrm{b} / \mathrm{m}^{3}$ at $760 \mathrm{~mm} \mathrm{Hg}$ and $20^{\circ} \mathrm{C}$ (equivalant value, $\mathrm{ppm}$ ). The maximum allowable exceedance rate, if any, follows. This refers to the maximum number of times per year that the standard may be exceeded. For example, $1 x$ means the standard may be exceeded only once per year.

(c) The averaging period is given in hours unless otherwise specified. AAM means Annual Arithmetic Mean Value and AGM means Annual Geometric Mean Value. 


\section{TABLE B-4. Threshold Limit Values
for Airborne Chemicals}

\begin{tabular}{|c|c|}
\hline Substance & $\begin{array}{l}\text { TLV } \\
\mathrm{mg} / \mathrm{m}^{3} \text { at } \\
760 \mathrm{~mm} \mathrm{Hg} \\
\text { and } 25^{\circ} \mathrm{C}\end{array}$ \\
\hline Acetone & 2400 \\
\hline Aldehyde (formaldehyde) & 5.0 \\
\hline Amine (diethylamine) & 75 \\
\hline Ammonia & 18 \\
\hline Ammonium diurnate & $0.2^{(b)}$ \\
\hline Ammonium fluoride & none \\
\hline Argon & none ${ }^{(c)}$ \\
\hline Arsine & 0.2 \\
\hline Boric acid & none \\
\hline Cadmium & 0.05 \\
\hline Carbon dioxide & 9000 \\
\hline Carbon monoxide & 55 \\
\hline Fluorine & 2 \\
\hline Hel ium & none $e^{(c)}$ \\
\hline Hydrogen & none $(c)$ \\
\hline Hydrogen fluoride & 2 \\
\hline Hydrogen sulfide & 15 \\
\hline Lead & 0.15 \\
\hline Nickel chloride & $0.1^{(d)}$ \\
\hline Nickel sulfate & $0.1^{(d)}$ \\
\hline Nitric acid & 5.0 \\
\hline Organic acid (acetic) & 25 \\
\hline Oxalic acid & 1 \\
\hline Phosphoric acid & 1 \\
\hline
\end{tabular}

(a) Threshold Limit Values of chemical substances and physical agents in the workroom environment with intended changes for 1976, American Conference of Governmental Industrial Hygienists, Cincinnati, $\mathrm{OH}, 1976$.

(b) As uranium.

(c) Simple asphyxiant.

(d) As nickel. 
TABLE B-4. (cont)

\begin{tabular}{|c|c|}
\hline Substance & $\begin{array}{c}T L Y \\
\mathrm{mg} / \mathrm{m}^{3} \mathrm{at} \\
760 \mathrm{mmH} \\
\text { and } 25^{\circ} \mathrm{C}\end{array}$ \\
\hline Plutonium dioxide & none \\
\hline R-114 fluorocarbon & none \\
\hline Stibine & 0.5 \\
\hline Sulfuric acid & 1 \\
\hline Tributyl phosphate & 5 \\
\hline Trichloroethylene & 535 \\
\hline Uranium dioxide & $0.2^{(b)}$ \\
\hline Uranium oxide & $0.2^{(b)}$ \\
\hline Uranium trioxide & $0.2^{(b)}$ \\
\hline Uranyl fluoride & $0.2^{(b)}$ \\
\hline Zinc & 5.0 \\
\hline
\end{tabular}

(b) As uranium

- Uranium Fuel Fabrication Plant

- Mixed Oxide Fuel Fabrication Plant

- Pressurized Water Reactor

- Boiling Water Reactor

- Fuel Reprocessing Plant

For each facility the existing environmental standards have been matched with the chemical effluents. These results are presented in Tables B-5 through B-14. Wherever possible, emission standards for similar processes have been identified. While these standards do not legally apply now, they do provide guidance for standards that may be enacted for nuclear fuel cycle facilities in the future.

Some chemicals emitted from the nuclear fuel cycle have no environmental standards. Chemicals such as argon and helium do not have standards because they are inert, and will not have standards as long as there is sufficient oxygen present that they do not pose any health hazard. However, if a chemical is thought to be detrimental to human health and yet does not have a standard, then safe exposure levels will be estimated based upon published results of animal exposure experiments. This approach may be used for the boric acid mist emitted from the uranium fuel fabrication plant. 
TABLE B-5. Environmental Standards for Gaseous Chemical Effluents from Surface Mining

Chemical
Free silica dust
Carbon monoxide $(c)$
Nitrogen oxides (c)
Sulfur dioxide (c)
Aldehydes $(c)$
Particulates $(c)$
Hydrocarbons $(c)$

\begin{tabular}{c} 
Source \\
Emission \\
Standard \\
\hline none \\
none \\
none \\
none \\
none \\
none \\
none
\end{tabular}

\section{Primary. Ambient Air Quality} Standard $\left(\mu \mathrm{g} / \mathrm{m}^{3}\right.$ at $760 \mathrm{mmHg}$ and $20^{\circ} \mathrm{C}$ )

$$
75^{(a)}
$$$$
10,000^{(d)}
$$$$
100(\mathrm{e})
$$$$
80^{(g)}
$$

none

$$
75^{(a)}
$$$$
160^{(i)}
$$

Threshold Limit
Value (mg/m $/ \mathrm{m}^{3} \mathrm{at}$
$760 \mathrm{mmHg}$ and $\left.25^{\circ} \mathrm{C}\right)$

(b)

55

13

(a) Annual gemotric mean for particulate matter, $260 \mu \mathrm{g} / \mathrm{m}^{3} 24 \mathrm{hr}$ average not to be exceeded more than once per year.

(b) Depends upon percent crystalline form (quartz).

(c) Emissions from diesel-powered vehicles used in mining.

(d) 8-hr average not to be exceeded more than once a year.

(e) Annual arithmetic mean as $\mathrm{NO}_{2}$.

(f) As $\mathrm{NO}_{2}$.

(g) Annual arithmetic mean as $\mathrm{SO}_{2} ; 365 \mu \mathrm{g} / \mathrm{m}^{3} 24 \mathrm{hr}$ average not to be exceeded more than once per year.

(h) Depends upon chemical formula.

(i) 3-hr average as methane not to be exceeded more than once per year. 
TABLE B-6. Environmental Standards for Gaseous

Chemical Effluents from Underground Mining

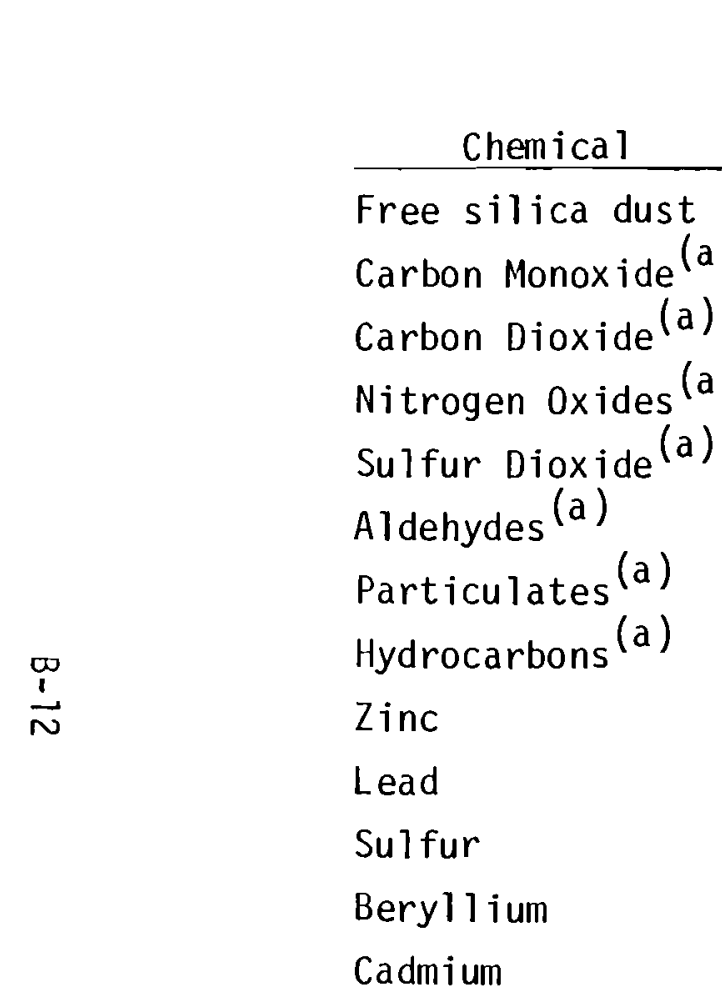

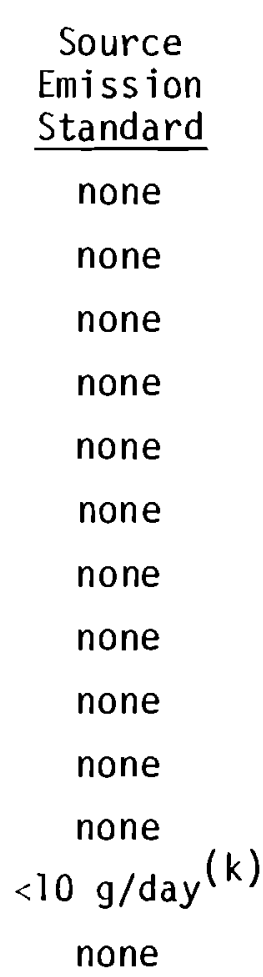

\begin{tabular}{l} 
Primary Ambient \\
Air Quality 3 at \\
Standard $\left(\mu \mathrm{g} / \mathrm{m}^{\circ}\right.$ at \\
$760 \mathrm{mmHg}$ and $\left.20^{\circ} \mathrm{C}\right)$ \\
\hline $75^{(\mathrm{b})}$ \\
$10,000^{(\mathrm{c})}$ \\
none \\
$75^{(\mathrm{d})}$ \\
$80^{(\mathrm{e})}$ \\
none \\
$75^{(\mathrm{b})}$ \\
$160^{(\mathrm{i})}$ \\
none \\
none \\
none \\
$0.01(\mathrm{k})$ \\
none
\end{tabular}

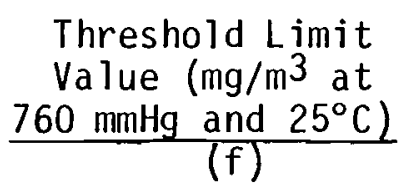

55

9000

13

0.15

none

0.002

0.05

(a) Emissions from diesel-powered vehicles used in mining.3

(b) Annual geometric mean for particulate matter; $260 \mu \mathrm{g} / \mathrm{m}^{3} 24 \mathrm{hr}$ average not to be exceeded

more than once per year.
(c) $8-\mathrm{hr}$ average not to be exceeded more than once per year; $40,000 \mathrm{\mu g} / \mathrm{m}^{3} 1-\mathrm{hr}$ average not to be exceeded more than once per year.

(d) Annual arithmetic mean as $\mathrm{NO}_{2}$.

(e) Annual arithmetic mean as $\mathrm{SO}_{2} ; 365 \mu \mathrm{g} / \mathrm{m}^{3} 24-\mathrm{hr}$ average not to be exceeded more than once per year.

(f) Depends upon percent crystalline form (quartz).

(g) As $\mathrm{NO}_{2}$.

(h) Depends upon chemical formula.

(i) 3-hr average as methane not to be exceeded more than once per year.

(j) As an oxide.

(k) National Emission Standard for beryllium processing and use. 


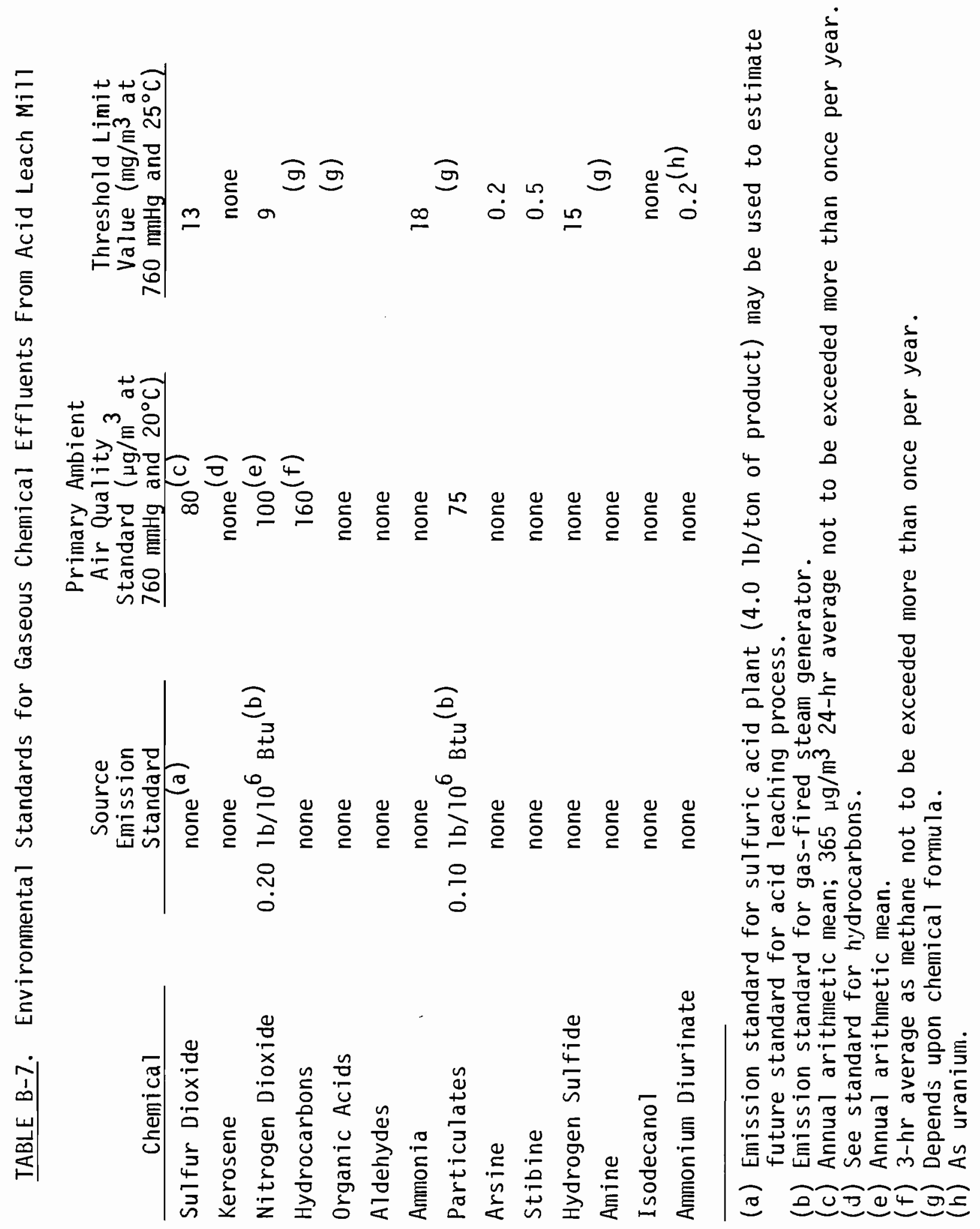




\section{TABLE B-8. Environmental Standards for Gaseous Chemical Effluents from Aqueous Conversion Plant}

\begin{tabular}{|c|c|c|c|}
\hline Chemical & $\begin{array}{l}\text { Source } \\
\text { Emission } \\
\text { Standard }\end{array}$ & $\begin{array}{l}\text { Primary Ambient } \\
\text { Air Quality } \\
\text { Standard }\left(\mathrm{\mu g} / \mathrm{m}^{3} \text { at }\right. \\
\left.760 \mathrm{mmHg} \text { and } 20^{\circ} \mathrm{C}\right) \\
\end{array}$ & $\begin{array}{r}\text { Threshold Limit } \\
\text { Value (mg/m } 3 \mathrm{at} \\
\left.760 \mathrm{mmHg} \text { and } 25^{\circ} \mathrm{C}\right) \\
\end{array}$ \\
\hline Nitrogen Oxides & none $e^{(a)}$ & $100^{(d)}$ & $9^{(i)}$ \\
\hline Hydrogen & none & none & none $e^{(j)}$ \\
\hline Hydrogen Sulfide & none & none & 15 \\
\hline Fluorine & none $e^{(b)}$ & none & 2 \\
\hline Hydrogen Fluoride & none ${ }^{(b)}$ & none & 2 \\
\hline Ammonium Diurinate Dust & none & none & $0.2^{(k)}$ \\
\hline Nitric Acid & none & none & 5 \\
\hline Uranium Dioxide Dust & none & none & $0.2^{(k)}$ \\
\hline Uranium Trioxide Dust & none & none & $0.2^{(k)}$ \\
\hline Hexane & none & $160^{(e)}$ & 360 \\
\hline Particulate $(c)$ & $0.101 \mathrm{~b} / 10^{6} \mathrm{Btu}$ & $75^{(f)}$ & $10^{(m)}$ \\
\hline Sulfur Dioxide ${ }^{(c)}$ & none & $80^{(g)}$ & 13 \\
\hline Carbon Monoxide ${ }^{(c)}$ & none & $10,000^{(h)}$ & \\
\hline Hydrocarbons $(c)$ & none & $160^{(e)}$ & (m) \\
\hline Nitrogen Oxides $(c)$ & $0.20 \mathrm{lb} / 10^{6} \mathrm{Btu}$ & 100 & $g^{(i)}$ \\
\hline
\end{tabular}

(a) Emission standard for nitric acid production may provide estimate for future standard $(3.0 \mathrm{lb} /$ ton of product).

(b) Emission standard for fertilizer production may provide estinate for future standard ( 0.01 to $0.21 \mathrm{~b} /$ ton of product).

(c) Emissions from gas-fired steam generator.

(d) Annual arithmetic mean as $\mathrm{NO}_{2}$.

(e) 3-hr average as methane not be be exceeded more than once per year.

(f) Annual geometric mean; $260 \mu \mathrm{g} / \mathrm{m}^{3} 24-\mathrm{hr}$ average not to be exceeded more than once per year.

(g) Annual arithmetic mean; $365 \mathrm{\mu g} / \mathrm{m}^{3}$ 24-hr average not to be exceeded more than once per year.

(h) 8-hr average not to be exceeded more than once per year; 40,000 $\mathrm{mg} / \mathrm{m}^{3} \mathrm{l}-\mathrm{hr}$ average not to be exceeded more than once per year.

(i) As $\mathrm{NO}_{2}$.

(j) Simple asphyxiant.

(k) As uranium.

(1) Nuisance particles.

(m) Depends upon chemical formula. 
TABLE B-9. Environmental Standards for Gaseous Chemical Effluents from Gaseous Diffusion Enrichment Plant

\begin{tabular}{|c|c|c|c|}
\hline Chemical & $\begin{array}{l}\text { Source } \\
\text { Emission } \\
\text { Standard } \\
\end{array}$ & $\begin{array}{l}\text { Primary Ambient } \\
\text { Air Quality } \\
\text { Standard }\left(\mu \mathrm{g} / \mathrm{m}^{3} \mathrm{at}\right. \\
\left.760^{\circ} \mathrm{mmHg} \text { and } 20^{\circ} \mathrm{C}\right) \\
\end{array}$ & $\begin{array}{l}\text { Threshold Limit } \\
\text { Value (mg/m } 3^{3} \text { at } \\
\left.760 \mathrm{mmHg} \text { and } 25^{\circ} \mathrm{C}\right) \\
\end{array}$ \\
\hline Hydrogen Fluoride & none & none & 2 \\
\hline Nitrogen Oxides (a) & $0.71 \mathrm{~b} / 10^{6} \mathrm{Btu}$ & $100^{(c)}$ & $g^{(i)}$ \\
\hline Sulfur Dioxide ${ }^{(a)}$ & $1.21 \mathrm{~b} / 10^{6} \mathrm{Btu}$ & $80^{(d)}$ & 13 \\
\hline Particulates (a) & $0.10 \mathrm{lb} / 10^{6} \mathrm{Btu}$ & $75^{(e)}$ & $10^{(j)}$ \\
\hline Carbon Dioxide ${ }^{(a)}$ & none & none & 9000 \\
\hline Carbon Monoxide (a) & none & $10,000^{(f)}$ & 55 \\
\hline Hydrocarbons $(\mathrm{a})$ & none & $160^{(9)}$ & $(k)$ \\
\hline Water Vapor & none & none & none \\
\hline Trichloroethylene & none & none & 535 \\
\hline Freon & none & none & none \\
\hline $\begin{array}{l}\text { Potassium } \\
\text { Dichromate }\end{array}$ & none & none & none \\
\hline Ammonia & none & none & 18 \\
\hline Uranium Particles & none & none & $0.2^{(1)}$ \\
\hline Acetone & none & none & 2400 \\
\hline Xyๆ01 & none & none & none \\
\hline Kerosene & none & none ${ }^{(h)}$ & none \\
\hline Fluorine & none & none & 2 \\
\hline Chlorothene & none & none & none \\
\hline
\end{tabular}

\footnotetext{
(a) Coal-fired steam generator.

(b) Cooling tower mist.

(c) Annual arithmetic mean.

(d) Annual arithmetic mean; $365 \mu \mathrm{g} / \mathrm{m}^{3} 24 \mathrm{hr}$ average not to be exceeded more than once per year.

(e) Annual geometric mean; $260 \mu \mathrm{g} / \mathrm{m}^{3} 24 \mathrm{hr}$ average not to be exceeded more than once per year.

(f) $8-h r$ average not to be exceeded more than once per year; $40,000 \mu \mathrm{g} / \mathrm{m}^{3}$ 1-hr average not to be exceeded more than once per year.

(g) 3-hr average as methane not to be exceeded more than once per year.

(h) See standard for hydrocarbons.

(i) As $\mathrm{NO}_{2}$.

(j) Nuisance particles.

(k) Depends on chemical formula.

(1) As uranium.
} 


\section{TABLE B-10. Environmental Standards for Gaseous Chemical Effluents}

from Uranium Fuel Fabrication Plant

\begin{tabular}{|c|c|c|c|}
\hline Chemical & $\begin{array}{l}\text { Source } \\
\text { Emission } \\
\text { Standard } \\
\end{array}$ & $\begin{array}{l}\text { Primary Ambient } \\
\text { Air Quality } \\
\text { Standard }\left(\mathrm{g} / \mathrm{m}^{3} \text { at }\right. \\
\left.760 \mathrm{mmHg} \text { and } 20^{\circ} \mathrm{C}\right) \\
\end{array}$ & $\begin{array}{l}\text { Threshold Limit } \\
\text { Value (mg/m at } \\
\left.760 \mathrm{mmHg} \text { and } 25^{\circ} \mathrm{C}\right) \\
\end{array}$ \\
\hline Heli um & none & none & none ${ }^{(i)}$ \\
\hline Carbon Monoxide $(\bar{a})$ & none & $10,000^{(e)}$ & 55 \\
\hline Argon & none & none & none $(i)$ \\
\hline Carbon Dioxide ${ }^{(a)}$ & none & none & 9000 \\
\hline Hydrogen & none & none & none ${ }^{(i)}$ \\
\hline Hydrocarbons (a) & none & $160^{(f)}$ & (j) \\
\hline Nitrogen & none & none & none \\
\hline Ammonia & none & none & 18 \\
\hline \multirow{2}{*}{$\begin{array}{l}\text { Hydrogen Fluoride } \\
\text { Nitrogen Oxides }(a)\end{array}$} & none ${ }^{(b)}$ & none & 2 \\
\hline & $0.71 \mathrm{~b} / 10^{6} \mathrm{Btu}$ & $100^{(g)}$ & $9^{(k)}$ \\
\hline Nitric Acid Mist & none $(c)$ & none & 5 \\
\hline Sulfuric Acid Mist & none ${ }^{(d)}$ & none & 1 \\
\hline Boric Acid Mist & none & none & none \\
\hline Nickel Sulfate & none & $75^{(h)}$ & $0.1^{(1)}$ \\
\hline Nickel Chloride & none & $75^{(h)}$. & $0.1(1)$ \\
\hline Ammonium Diurante & none & none & $\cdot 0.2^{(\mathrm{m})}$ \\
\hline Uranyl Fluoride & none & none & $0.2^{(m)}$ \\
\hline Ammonium Fluoride & none & none & none \\
\hline \multirow{3}{*}{$\begin{array}{l}\text { Uranium Hexafluoride } \\
\text { Uranium Dioxide } \\
\text { Uranium Oxide }\left(\mathrm{U}_{3} \mathrm{O}_{8}\right)\end{array}$} & none & none & $0.2^{(m)}$ \\
\hline & none & none & $0.2^{(\mathrm{in})}$ \\
\hline & none & none & $0.2^{(\mathrm{m})}$ \\
\hline $\begin{array}{l}\text { (a) Emissions from } \\
\text { (b) Emission standa } \\
\text { to estimate fut } \\
\text { (c) Emission standa } \\
\text { of stack gas an } \\
\text { (d) Emission standa } \\
\text { used to estimat } \\
\text { (e) 8-hr average no } \\
\text { average not to } \\
\text { (f) 3-hr average as } \\
\text { (g) Annual arithmet } \\
\text { (h) Particulate mat } \\
\text { (i) Simple asphyxia } \\
\text { (j) Depends upon ch } \\
\text { (k) As Noz. } \\
\text { (1) Solubie compour } \\
\text { (m) As uranium. }\end{array}$ & $\begin{array}{l}\text { fossil-fueled at } \\
\text { rds for aluminum } \\
\text { ure standards fo } \\
\text { rd for nitric ac } \\
\text { d is therefore } \\
\text { rd for sulfuric } \\
\text { e future standar } \\
\text { t to be exceede } \\
\text { be exceeded mor } \\
\text { methane not to } \\
\text { ic mean as } \mathrm{NO}_{2} \text {. } \\
\text { ter, annual geor } \\
\text { nt. } \\
\text { emical formula. } \\
\text { ds as } \mathrm{Ni} \text {. }\end{array}$ & $\begin{array}{l}\text { iliary power. } \\
\text { reduction }(2.01 \mathrm{~b} / \mathrm{t} \\
\text { fuel fabrication } \mathrm{p} \\
\text { d plant applies to } \\
\text { t very helpful in e } \\
\text { cid plant }(0.151 \mathrm{~b} / \\
\text { is. } \\
\text { more than once a ye } \\
\text { than once per year. } \\
\text { be exceeded more tha } \\
\text { etric mean. }\end{array}$ & $\begin{array}{l}\text { of product may be used } \\
t \text {. } \\
\text { emission and opacity } \\
\text { imating future standards } \\
n \text { of product may be } \\
; 40,000 ; \mathrm{g} / \mathrm{m}^{3} 1-\mathrm{hr} \\
\text { once a year. }\end{array}$ \\
\hline
\end{tabular}


TABLE B-11. Environmental Standards for Gaseous Chemical Effluents from Mixed Oxide Fuel Fabrication Plant

\begin{tabular}{|c|c|c|c|}
\hline Chemical & $\begin{array}{l}\text { Source } \\
\text { Emission } \\
\text { Standard } \\
\end{array}$ & $\begin{array}{l}\text { Primary Ambient } \\
\text { Air Quality } \\
\text { Standard }\left(\mu \mathrm{g} / \mathrm{m}^{3} \text { at }\right. \\
\left.760 \mathrm{mmHg} \text { and } 20^{\circ} \mathrm{C}\right) \\
\end{array}$ & $\begin{array}{l}\text { Threshold Limit } \\
\text { Value (mg/m } 3 \text { at } \\
\left.760 \mathrm{mmHg} \text { and } 25^{\circ} \mathrm{C}\right)\end{array}$ \\
\hline Sulfur Trioxide & none & none & none \\
\hline Nitrogen Dioxide & none & $100^{(a)}$ & 9 \\
\hline Nitrogen & none & none & none \\
\hline Hydrogen & none & none & (b) \\
\hline Helium & none & none & $(b)$ \\
\hline Water Vapor & none & none & none \\
\hline Uranium Dioxide & none & none & $0.2^{(c)}$ \\
\hline Plutonium Dioxide & none & none & none \\
\hline
\end{tabular}

\footnotetext{
(a) Annual arithmetic mean.

(b) Simple asphyxiant.

(c) As uranium.
} 
TABLE B-12. Environmental Standards for Gaseous Chemical Effluents from Pressurized Water Reactor

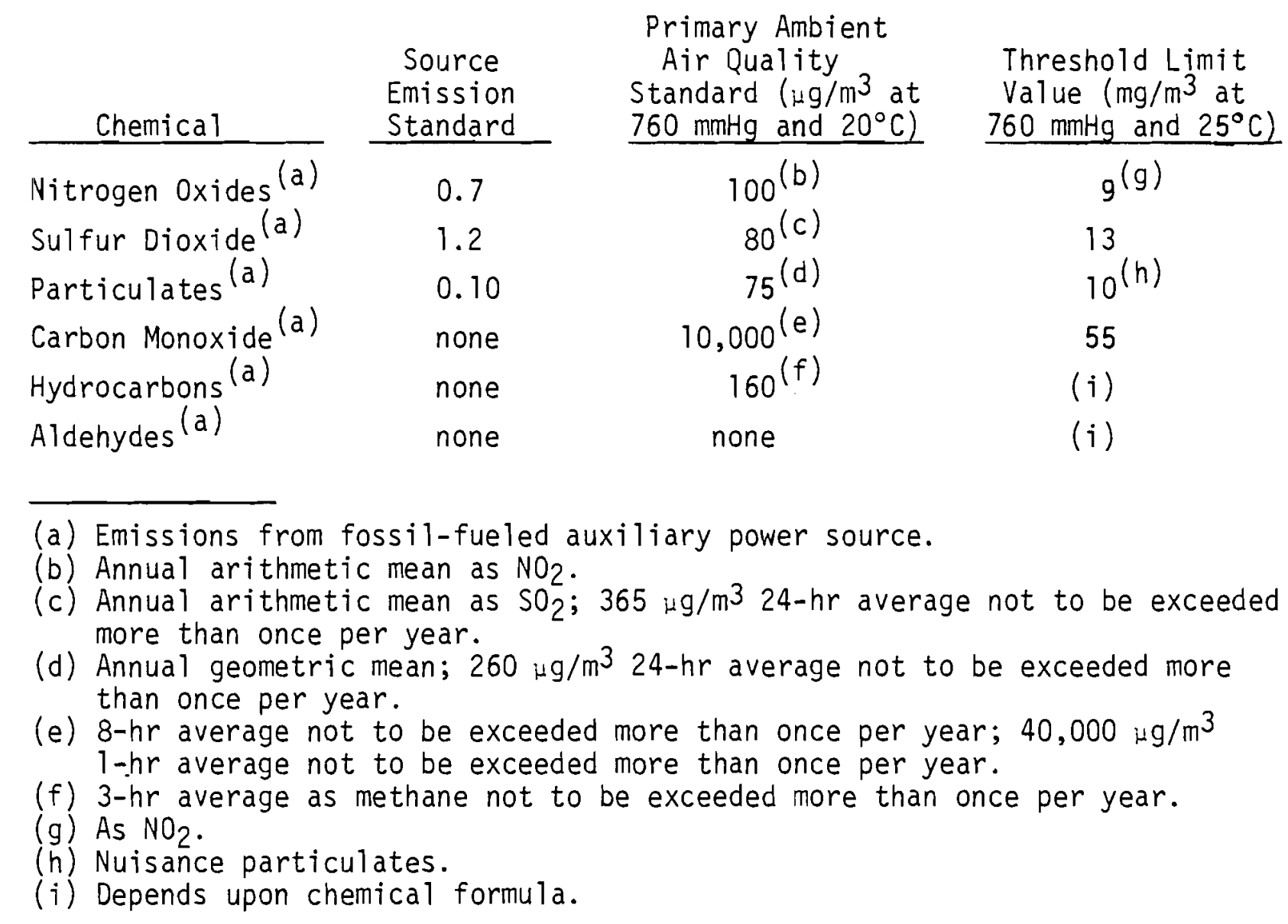


TABLE B-13. Environmental Standards for Gaseous Chemical Effluents from Boiling Water Reactor

\begin{tabular}{|c|c|c|c|}
\hline Chemical & $\begin{array}{l}\text { Source } \\
\text { Emission } \\
\text { Standard } \\
\end{array}$ & $\begin{array}{l}\text { Primary Ambient } \\
\text { Air Quality } \\
\text { Standard }\left(\mu \mathrm{g} / \mathrm{m}^{3} \text { at }\right. \\
\left.760 \mathrm{mmHg} \text { and } 20^{\circ} \mathrm{C}\right) \\
\end{array}$ & $\begin{array}{l}\text { Threshold Limit } \\
\text { Value (mg/m } 3 \text { at } \\
\left.760 \mathrm{mmHg} \text { and } 25^{\circ} \mathrm{C}\right) \\
\end{array}$ \\
\hline A1dehydes (a) & none & none & (g) \\
\hline Carbon Monoxide ${ }^{(a)}$ & none & $10,000^{(b)}$ & 55 \\
\hline Hydrocarbons $(a)$ & none & $160^{(c)}$ & $(g)$ \\
\hline Nitrogen Oxides (a) & 0.7 & $100^{(d)}$ & (h) \\
\hline Sulfur Oxides (a) & 1.2 & $80^{(e)}$ & (i) \\
\hline Particulates $(a)$ & 0.10 & $75^{(f)}$ & $(j)$ \\
\hline
\end{tabular}

(a) Emissions from fossil-fueled auxiliary power source.

(b) 8-hr average not to be exceeded more than once per year; 40,000 $\mathrm{\mu g} / \mathrm{m}^{3}$ $1-h r$ average not to be exceeded more than once per year.

(c) 3-hr average as methane not to be exceeded more than once per year.

(d) Annual arithmetic mean as $\mathrm{NO}_{2}$.

(e) Annual arithmetic mean as $\mathrm{SO}_{2} ; 365 \mu \mathrm{g} / \mathrm{m}^{3} 24-\mathrm{hr}$ average not to be exceeded more than once per year.

(f) Annual geometric mean; $260 \mu \mathrm{g} / \mathrm{m}^{3} 24-\mathrm{hr}$ average not to be exceeded more than once per year.

(g) Depends upon chemical formula.

(h) $\mathrm{As} \mathrm{NO}_{2}$.

(i) $\mathrm{As}^{\mathrm{SO}}$.

(j) Nuisance particles. 
TABLE B-14. Environmental Standards for Gaseous Chemical Effluents from Fuel Reprocessing Plant

\begin{tabular}{|c|c|c|c|}
\hline Chemical & $\begin{array}{l}\text { Source } \\
\text { Emission } \\
\text { Standard } \\
\end{array}$ & $\begin{array}{l}\text { Primary Ambient } \\
\text { Air Quality } \\
\text { Standard }\left(\mu \mathrm{g} / \mathrm{m}^{3} \mathrm{at}\right. \\
\left.760 \mathrm{mmHg} \text { and } 20^{\circ} \mathrm{C}\right) \\
\end{array}$ & $\begin{array}{l}\text { Threshold Limit } \\
\text { Value }\left(\mathrm{mg} / \mathrm{m}^{3} \mathrm{at}\right. \\
\left.760 \mathrm{mmHg} \text { and } 25^{\circ} \mathrm{C}\right) \\
\end{array}$ \\
\hline \multirow{2}{*}{$\begin{array}{l}\text { Ammonia } \\
\text { Carbon Monoxide (a) }\end{array}$} & none & none & 18 \\
\hline & none & $10,000(c)$ & 55 \\
\hline Carbon Dioxide & none & none & 9000 \\
\hline Hydrogen & none & none & none ${ }^{(h)}$ \\
\hline Hyarogen Fluoride & none & none & 2 \\
\hline Hydrogen Sulfide & none & none & 15 \\
\hline \multirow{2}{*}{ Nitrogen Oxides } & none $(b)$ & $100^{(d)}$ & $9^{(i)}$ \\
\hline & $1.21 \mathrm{~b} / 10^{6} \mathrm{Btu}$ & $80^{(e)}$ & 13 \\
\hline Particulates $(a)$ & $0.11 \mathrm{~b} / 10^{6} \mathrm{Btu}$ & $75^{(f)}$ & $10^{(j)}$ \\
\hline Dodecane & none ${ }^{(g)}$ & 160 & none \\
\hline Tributyl Phosphate & none & none & 5 \\
\hline Oxalic Acid & none & none & 1 \\
\hline Nitric Acid & none & none & 5 \\
\hline Uranium Dioxide & none & none & $0.2^{(d)}$ \\
\hline Uranium Trioxide & none & none & $0.2^{(k)}$ \\
\hline Uranyl Fluoride & none & none & $0.2^{(k)}$ \\
\hline Sulfuric Acid & none & none & 1 \\
\hline R-114 Fluorocarbon & none & none & none \\
\hline \multirow{2}{*}{$\begin{array}{l}\text { Fluorine } \\
\text { Phosphoric Acid }\end{array}$} & none & none & 2 \\
\hline & none & none & 1 \\
\hline \multicolumn{4}{|c|}{$\begin{array}{l}\text { (a) Mostly from auxiliary power generation. } \\
\text { (b) Emission standard for nitric acid plant }(3.01 \mathrm{~b} / \text { ton of product may be used } \\
\text { to estimate future standard. } \\
\text { (c) 8-hr average not to be exceeded more than once a year; } 40,000 \mathrm{\mu g} / \mathrm{m}^{3} 1-\mathrm{hr} \\
\text { average not to be exceeded more than once a year. } \\
\text { (d) Annual arithmetic mean as } \mathrm{NO}_{2} \text {. } \\
\text { (e) Annual arithmetic mean as } \mathrm{SO}_{2} ; 365 \mathrm{\mu g} / \mathrm{m}^{3} 24-\mathrm{hr} \text { average not to be exceeded } \\
\text { more than once per year. } \\
\text { (f) Annual geometric mean; } 260 \mu \mathrm{g} / \mathrm{m}^{3} 24-\mathrm{hr} \text { average not to be exceeded more than } \\
\text { once a year. } \\
\text { (g) } 3-\mathrm{hr} \text { average as methane not to be exceeded more than once per year. } \\
\text { (h) Simple asphyxiant. } \\
\text { (i) As N02. } \\
\text { (j) Nuisance particles. } \\
\text { (k) As uranium. }\end{array}$} \\
\hline
\end{tabular}


FUTURE ENVIRONMENTAL STANDARDS FOR NUCLEAR FUEL CYCLE FACILITIES

The EPA is presently developing performance standards for the following industrial categories.

- Kraft pulp mills

- Grain terminals

- Chlor-alkali plants

- By-product coke ovens

- Lime plants

- Refuse combustion for steam generation

- Carbon block plants

- Gray iron foundries

- Phosphate rock preparation

- Surface finishing operations--automobiles, appliances, paperboard, etc.

- Lead battery manufacturers

- Dry cleaning

- Solvent degreasing

In addition, preliminary studies are being conducted on the following sources, which may be subject to regulations depending upon the results of the survey.

- Ammonia

- Charcoar

- Explosives

- FCC unit catalyst regenerators

- Nonmetallic minerals industry

- Petroleum refinery vacuum distillation

- Petroleum refinery miscellaneous sources

- Adipic acid plants

- Dimethyl teraphthalate-teraphthalic acid plants

- Fiberglass

- Crude oil, jet fuel, and aviation gasoline transfer operations 
- Waste solvent reclaiming

- Low Btu coal gasification

- Coal-fired industrial boilers

- 0il- and gas-fired industrial boilers.

The EPA has approached the problem of regulations and standards on a priority basis; that is, those sources that exist in greatest numbers or emit highly hazardous chemicals are being addressed first. Therefore, none of the standards for the preceding lists of sources will apply specifically to nuclear fuel cycle facilities. Since nuclear fuel cycle facilities do not fall in either of the priority categories, such source performance standards for chemical effluents will probably not be developed under the Clean Air Act for at least the next 10 years.

The Toxic Substances Control Act of 1976 (Public Law 94-469) looms as a pending factor. ${ }^{(5)}$ It gives EPA widespread authority regarding the manufacture and use of chemicals. Manufacturers must prove that their products are not detrimental to human health. Nuclear materials have been specifically excluded from coverage by the Act. However, this does not mean that all of the chemicals used in nuclear fuel cycle processes are similariy excluded. It will be at least 2 years before the first EPA regulations are issued under this Act. A government interagency committee mus.t first publish a list of substances for testing. The EPA must then issue testing procedures so that the appropriate results can be obtained. 


\section{REFERENCES}

1. Standards of Performance for New Stationary Sources, Federal Register, December 23, 1971, 36FR 24876.

2. National Emission Standards for Hazardous Air Pollutants, Federal Register, April 6, 1973, 38FR 8820.

3. National Primary and Secondary Ambient Air Quality Standards, Federal Register, November 25, 1971, 36FR 22384.

4. Threshold Limit Values for Chemical Substances and Physical Agents in the Workroom Environment with Intended Changes for 1976, American Conference of Governmental Industrial Hygienists, Cincinnati, Ohio, 1976.

5. Toxic Substances Control Act, Congressional Records -- House, September 23, 1976, H11001. 

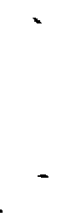

•

- 
APPENDIX $C$

ENVIRONMENTAL STANDARDS FOR LIQUID CHEMICAL EFFLUENTS 


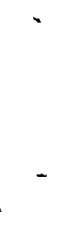

$\cdots$ 
APPENDIX C

\section{ENVIRONMENTAL STANDARDS FOR LIQUID CHEMICAL EFFLUENTS}

This appendix contains pertinent guidelines, water quality criteria and toxicity data for liquid chemicals discharged from the nuclear fuel cycle. These federal standards provide the bases for deciding if a chemical effluent requires control or if a process requires modification.

\section{FEDERAL EFFLUENT GUIDELINES AND STANDARDS}

Effluent guidelines and standards for industries are to implement Sections 304, 307, and 308 of the Federal Water Pollution Control Act, as amended (33 USC 1551, 1314, 86 Stat. 816 et. seq.) The guide1ines suggest the degree of effluent reduction attainable through the application of the "best practicable control technology currently available" (BPCTCA) and the degree of effluent reduction attainable through the application of the "best available technology economically achievable" (BATEA) which must be achieved by existing point sources by July 1, 1977 and July 1, 1983, respectively. (1) Guidelines have been developed for the industries and activities shown in Table $C-1$. The specific section of the Code of Federal Regulations (CFR) is also listed.

\section{WATER QUALITY CRITERIA}

Water quality criteria are based on Section 304(a), of the Federal water Pollution Control Act Amendments of 1972 which provide that within 1 year of enactment (by October 18, 1973) the EPA "shal1 publish and revise from time to time thereafter, water quality criteria."(2) Table C-2 lists the criteria for the "most critical use." This category is the most stringent standard for seven categories of water uses.

1. Agriculture irrigation

2. Agriculture livestock

3. Freshwater (aquatic life) 
TABLE C-1. Effluent Guidelines and Standards

Environmental Protection Agency Regulations on Public Hearings on Effluent Standards for Toxic Pollutants (40 CFR 104)

General Provisions for Effluent Guidelines and Standards (40 CFR 401 and 402).

Dairy Products (40 CFR 405)

Grain Mills (40 CFR 406)

Canned and Preserved Fruits and Vegetables (40 CFR 407)

Sugar Processing (40 CFR 409)

Textiles (40 CFR 410)

Cement Manufacturing (40 CFR 411)

Feed lots (40 CFR 412)

Electroplating (40 CFR 413)

Organic Chemicals (40 CFR 414)

Inorganic Chemicals (40 CFR 415)

Plastics and Synthetics (40 CFR 416)

Soaps and Detergents (40 CFR 417)

Fertilizer Manufacturing (40 CFR 418)

Petroleum Refining (40 CFR 419)

Iron and Steel Manufacturing (40 CFR 420)

Nonferrous Metals (40 CFR 421)

Phosphate Manufacturing (40 CFR 422)

Steam Electric Power Generating (40 CFR 423)

Ferroalloy Manufacturing (40 CFR 424)

Leather Tanning and Finishing (40 CFR 425)

Glass Manufacturing (40 CFR 426)

Asbestos Manufacturing (40 CFR 427)

Rubber Processing (40 CFR 428)

Timber Products (40 CFR 429)

Pulp, Paper and Paper Board (40 CFR 430)

Builders Paper and Board Mills (40 CFR 431)

Meat Products (40 CFR 432)

Coal Mining (40 CFR 434)

offshore $0 i 1$ and Gas Extraction (40 CFR 435) 


\section{TABLE C-1. (cont)}

Mineral Mining and Processing (40 CFR 436)

Pharmaceutical Manufacturing (40 CFR 439)

Ore Mining and Dressing (40 CFR 440)

Paving and Roofing Materials (40 CFR 443)

Paint Formulating (40 CFR 446)

Ink Formulating (40 CFR 447)

Gum and Wood Chemicals Manufacturing (40 CFR 454)

Pesticides Chemicals Manufacturing (40 CFR 455)

Explosives Manufacturing (40 CFR 457)

Carbon Black Manufacturing (40 CFR 458)

Photographic Processing (40 CFR 459)

Hospitals (40 CFR 460) 
TABLE C-2. Most Critical Use Water Quality Parameters

\begin{tabular}{|c|c|c|c|c|}
\hline \multirow[b]{2}{*}{ Parameter } & \multirow[b]{2}{*}{ Most Critical Use } & \multicolumn{3}{|c|}{ Value } \\
\hline & & EPA & NAS(a) & NTAC $(b)$ \\
\hline $\mathrm{pH}$ & $\begin{array}{l}\text { Freshwater wild- } \\
\text { life }\end{array}$ & $6-9$ & $7-9.2$ & $7-9.2^{\circ}$ \\
\hline $\mathrm{BOD}_{5}$ & -- & -- & -- & -- \\
\hline Nitrates & $\begin{array}{l}\text { Freshwater public } \\
\text { supply }\end{array}$ & $10 \mathrm{mg} / 1$ & $10 \mathrm{mg} / 1$ & $10 \mathrm{mg} / 1$ \\
\hline $\begin{array}{c}\text { Phosphorous } \\
\text { (total) }\end{array}$ & $\begin{array}{l}\text { Freshwater aquatic } \\
\text { life }\end{array}$ & -- & $\begin{array}{l}\text { Maintain } \mathrm{NO}_{3} \\
-\mathrm{PO}_{4} \text { ratio } \\
\text { Maintain } \mathrm{NH}_{4} \\
-\mathrm{PO}_{4} \text { ratio }\end{array}$ & -- \\
\hline Chromium & $\begin{array}{l}\text { Freshwater aquatic } \\
\text { life }\end{array}$ & $0.05 \mathrm{mg} / 1$ & $0.05 \mathrm{mg} / \mathrm{l}$ & $0.02 \mathrm{mg} / 1$ \\
\hline Coliform & Recreational waters & $\begin{array}{l}\text { Same as } \\
\text { NTAC }\end{array}$ & -- & $\begin{array}{l}\text { Primary contact } \\
200 / 100 \mathrm{ml} \\
\text { Secondary contact } \\
2000 / 100 \mathrm{ml}\end{array}$ \\
\hline Cyanide & $\begin{array}{l}\text { Freshwater aquatic } \\
\text { life }\end{array}$ & $1 / 20$ LC50 & $\begin{array}{r}1 / 20 \mathrm{LC} 50 \\
0.005 \mathrm{mg} / 1\end{array}$ & $\begin{array}{l}\text { Flow through } \\
\text { bioassays }\end{array}$ \\
\hline Mercury & $\begin{array}{l}\text { Freshwater public } \\
\text { supply }\end{array}$ & $0.002 \mathrm{mg} / 1$ & $0.002 \mathrm{mg} / \mathrm{l}$ & -- \\
\hline Lead & $\begin{array}{l}\text { Marine water } \\
\text { aquatic life }\end{array}$ & $\begin{array}{l}1 / 50 \mathrm{LC} 50 \\
1 / 100 \mathrm{LC} 50 \\
0.05 \mathrm{mg} / 1\end{array}$ & $\begin{array}{l}1 / 50 \mathrm{LC} 50 \\
1 / 100 \mathrm{LC} 50 \\
0.05 \mathrm{mg} / 1\end{array}$ & -- \\
\hline Copper & $\begin{array}{l}\text { Freshwater aquatic } \\
\text { life } \\
\text { Marine water } \\
\text { aquatic life }\end{array}$ & $\begin{array}{l}1 / 10 \text { LC50 } \\
1 / 100 \text { LC50 }\end{array}$ & $\begin{array}{l}1 / 10 \text { LC50 } \\
1 / 100 \text { LC } 50\end{array}$ & $\begin{array}{l}\mathrm{TLM}=0.02 \mathrm{mg} / \mathrm{l} \\
1 / 10 \mathrm{TLM}-1 / 30 \\
\mathrm{TLM}\end{array}$ \\
\hline Zinc & $\begin{array}{l}\text { Freshwater aquatic } \\
\text { life }\end{array}$ & $5 / 1000$ LC50 & $5 / 1000$ LC50 & $1 / 100$ LC50 \\
\hline Cadmium & $\begin{array}{l}\text { Freshwater aquatic } \\
\text { life }\end{array}$ & $\begin{array}{l}0.03 \mathrm{mg} / \mathrm{I}(\mathrm{c}) \\
0.004 \mathrm{mg} / \mathrm{d}) \\
0.003 \mathrm{mg} / \mathrm{l}(\mathrm{e}) \\
0.0005 \mathrm{mg} / \mathrm{I} \text { (f) }\end{array}$ & Same as EPA & $\begin{array}{l}\text { 1/30 TLM at any } \\
\text { time or place } \\
\text { 1/500 TLM } 24-\mathrm{hr} \\
\text { avg. }\end{array}$ \\
\hline
\end{tabular}

(a) National Academy of Science

(b) National Technical Advisory Committee

(c) Hard water all organisms

(d) Soft water all organisms

(e) Hard water salmon eggs larvae, crusta ians

(f) Soft water 


\section{TABLE C-2. (cont)}

\begin{tabular}{|c|c|c|c|c|}
\hline \multirow{2}{*}{ Parameter } & \multirow[b]{2}{*}{ Most Critical Use } & \multicolumn{3}{|c|}{ Value } \\
\hline & & EPA & NAS & NTAC \\
\hline Temperature & $\begin{array}{l}\text { Freshwater aquatic } \\
\text { life }\end{array}$ & $\begin{array}{l}\text { 1) Streams } \\
\Delta \mathrm{T}<5^{\circ} \mathrm{F} \\
\text { Epilimnon } \\
\text { Lakes } \Delta \mathrm{T} \\
\leq 3^{\circ} \mathrm{F} \text { based } \\
\text { on monthly } \\
\text { avg. of max. } \\
\text { daily temp. } \\
\text { 2) Recommended } \\
\text { max. for } \\
\text { various } \\
\text { species } \\
\text { 3) No addition } \\
\text { to trout and } \\
\text { salmon waters }\end{array}$ & $\begin{array}{l}\text { Same as } \\
\text { EPA }\end{array}$ & $\begin{array}{l}\text { Avoid disrupt- } \\
\text { ing natural } \\
\text { patterns }\end{array}$ \\
\hline $\begin{array}{l}\text { Chlorine } \\
\text { (residual) }\end{array}$ & -- & -- & -- & -- \\
\hline TDS & $\begin{array}{l}\text { Freshwater public } \\
\text { supply }\end{array}$ & -- & -- & $500 \mathrm{mg} / \mathrm{l}$ \\
\hline Aluminum & Marine water & $1.5 \mathrm{mg} / 1$ & $\begin{array}{l}1.5 \mathrm{mg} / \mathrm{l} \\
0.2 \mathrm{mg} / \mathrm{l}\end{array}$ & 1/100 $96 \mathrm{TLm}$ \\
\hline Arsenic & $\begin{array}{l}\text { Agriculture (1ive- } \\
\text { stock) }\end{array}$ & $0.2 \mathrm{mg} / 1$ & $0.2 \mathrm{mg} / 1$ & $<.05 \mathrm{mg} / 1$ \\
\hline Barium & $\begin{array}{l}\text { Marine water } \\
\text { (aquatic life) }\end{array}$ & $\begin{array}{l}1 / 100 \mathrm{LC}_{50} \\
0.05 \mathrm{mg} / 1\end{array}$ & $\begin{array}{ll}/ 100 & \mathrm{LC}_{50} \\
0.05 & \mathrm{mg} / 1 \\
0.01 & \mathrm{mg} / 1\end{array}$ & -- \\
\hline Beryllium & Ag irrigation & $\begin{array}{ll}0.1 & \mathrm{mg} / 1 \\
0.5 & \mathrm{mg} / 1\end{array}$ & $\begin{array}{ll}0.1 \mathrm{mg} / 1 \\
0.5 \mathrm{mg} / 1\end{array}$ & $\begin{array}{l}0.5 \mathrm{mg} / 1 \\
1 \mathrm{mg} / 1\end{array}$ \\
\hline Boron & $\begin{array}{l}\text { Ag irrigation } \\
\text { sensitive plants }\end{array}$ & $0.75 \mathrm{mg} / 1$ & $0.75 \mathrm{mg} / 1$ & $0.75 \mathrm{mg} / 1$ \\
\hline Bromine & $\begin{array}{l}\text { Marine water } \\
\text { (aquatic life) }\end{array}$ & $\begin{array}{l}0.1 \mathrm{mg} / 1 \\
\text { free }\end{array}$ & $\begin{array}{l}0.1 \mathrm{mg} / \mathrm{l} \\
<100 \mathrm{mg} \text { bromats }\end{array}$ & : \\
\hline Cobalt & $\begin{array}{l}\text { Agriculture } \\
\text { (irrigation) }\end{array}$ & $\begin{array}{l}0.05 \mathrm{mg} / 1 \\
5 \mathrm{mg} / \mathrm{l}\end{array}$ & $\begin{array}{l}0.05 \mathrm{mg} / 1 \\
5.0 \mathrm{mg} / 1\end{array}$ & $\begin{array}{r}0.2 \mathrm{mg} / 1 \\
10.2 \mathrm{mg} / 1\end{array}$ \\
\hline
\end{tabular}


TABLE C-2. (cont)

Parameter Most Critical Use

Fluorine

Iron

Lithium

Manganese

Molybc̄enium

Nickel

Phosphorus

Selenium

Sodium

Silver

$\operatorname{Tin}$

Thallium

Uranium

Vanadium

$$
\begin{aligned}
& \text { Marine water } \\
& \text { (aquatic life) }
\end{aligned}
$$

Marine water

Marine water

(aquatic life)

Marine water

(aquatic life)

Agriculture

(irrigation)

Marine Water

(aquatic life)

Marine water

(aquatic life)

Agriculture

(livestock)

Freshwater (public supply) (aquatic life)

Value

$\overline{\mathrm{EPA}}-\mathrm{NAS}-\frac{\mathrm{NTAC}}{-}$

$1 / 10 \quad \mathrm{I}_{5} \mathrm{C}$
$0.5 \mathrm{mg} / 1$

$1 / 10 \quad L_{50}$

$1.5 \mathrm{mg} / \mathrm{I}$

$0.5 \mathrm{mg} / \mathrm{l}$

$0.3 \mathrm{mg} / 1$

$0.3 \mathrm{mg} / \mathrm{I}$

$0.05 \mathrm{mg} / \mathrm{I}$

$1 / 100$ LC $_{50}$

$0.005 \mathrm{mg} / \mathrm{l}$

$1 / 50 \mathrm{LC} 50$
$0.1 \mathrm{mg} / 1$

$1 / 50 \quad L_{50}$

$0.1 \mathrm{mg} / \mathrm{I}$

$0.02 \mathrm{mg} / 1$

$0.01 \mathrm{mg} / \mathrm{l}$

$0.06 \mathrm{mg} / 1$

$0.01 \mathrm{mg} / \mathrm{l}$

$0.05 \mathrm{mg} / \mathrm{l}$

$\begin{array}{rr}1 / 100 & \mathrm{LC}_{5} 9 \\ 0.1 \mathrm{mg} / \mathrm{I}\end{array}$

$1 / 100 \quad L_{5} C_{50}$

$1.0 \mathrm{ma} / \mathrm{I}$

$1 / 100$ LC50 1/100 LS50

$0.01 \mathrm{mg} / 1$

$0.01 \mathrm{mg} / \mathrm{I}$

$0.005 \mathrm{mg} / \mathrm{l}$

$0.05 \mathrm{mg} / \mathrm{I}$

$0.05 \mathrm{mg} / \mathrm{l}$

$0.01 \mathrm{mg} / 1$
$0.005 \mathrm{mg} / \mathrm{l}$

$0.05 \mathrm{mg} / \mathrm{l}$
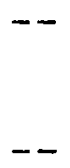

Drinking water criteria

0.2 
TABLE C-2. (cont)

- Parameter Most Critical Use

Alkalinity
Acidity

Carbon
dioxide
Bicarbonates
Ammonia

Freshwater

(aquatic life)

Freshwater

(aquatic life)

Agriculture

(Iivestock)

Marine water

(aquatic life)

Freshwater

(aquatic life)

Sulfates

Freshwater

(public supply)

Sulfides

Freshwater

(aquatic life)

salinity

Agriculture

(irrigation)

Hardness

Freshwater

(aquatic life)

Suspended and Freshwater

settleable (aquatic life)

solids

Turbidity and Freshwater

light pene- (wildlife)

trations

. Color

Freshwater

(aquatic life)

Tainting

substances

and odor
Freshwater

(public supply)

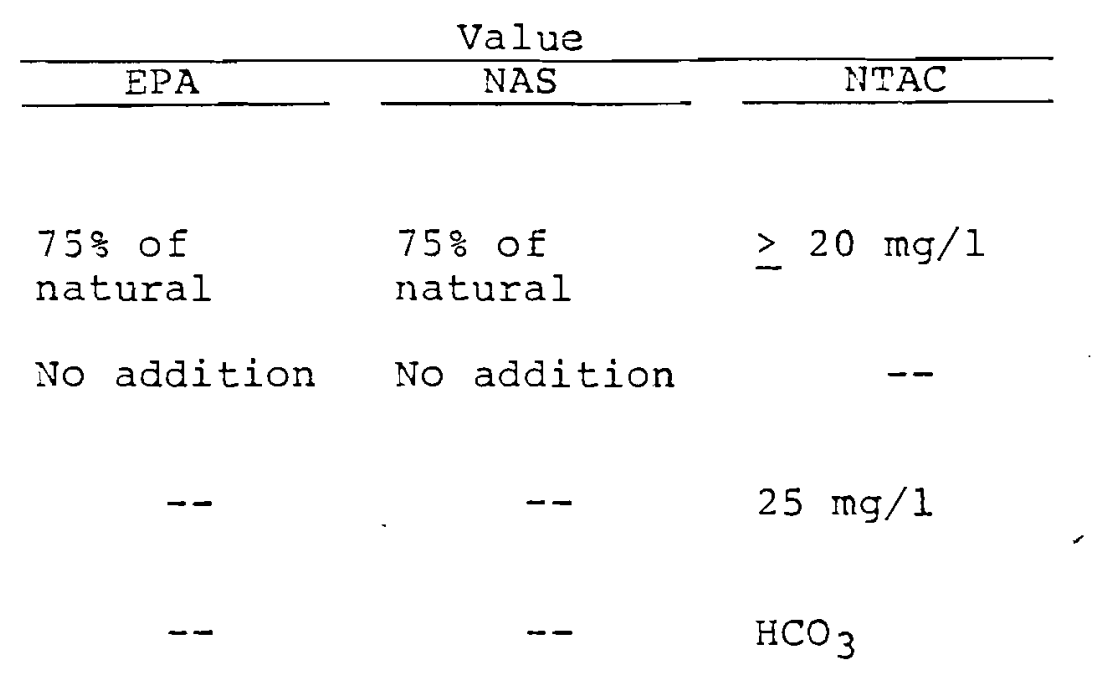
$1 / 20 \mathrm{LC}_{50}$ EPA Flow through $0.02 \mathrm{mg} / 1$ bioassay

$250 \mathrm{mg} / \mathrm{l} \quad 250 \mathrm{mg} / \mathrm{l} \quad 250 \mathrm{mg} / \mathrm{l}$

$0.002 \mathrm{mg} / \mathrm{l}$

$--\quad T D S$

Bioassays

$80 \mathrm{mg} / \mathrm{l}$

$25 \mathrm{mg} / \mathrm{l}$

$80 \mathrm{mg} / \mathrm{l}$

$400 \mathrm{mq} / 1$

$10 \%$ change

in compensation

point

10\% change

Same as EPA in

compensation point

$500-5000 \mathrm{mg} / \mathrm{l}$

Absent

Absent

Absent 
TABLE C-2. (cont)

Parameter Most Critical Use

Oils

Carbon

adsorbable

CCE

CAE

Phenols

Phthalate

esters

Polychlorinated

biphenyls

Freshwater

(public supply)

Freshwater

(aquatic life)

Freshwater

(aquatic life)
Freshwater

(public supply)

Freshwater

(public supply)

$0.3 \mathrm{mg} / \mathrm{l}$

$1.5 \mathrm{mg} / \mathrm{l}$

No visible

oils
Value NAS

$-\cdots$

Virtually absent
$0.3 \mathrm{mg} / \mathrm{I}$

$1.5 \mathrm{mg} / 1$

Freshwater

(public supply)

Radioactivity

Dissolved

oxygen
Freshwater

(wildlife)
$0.001 \mathrm{mg} / \mathrm{l}$

$0.3 \mu \mathrm{g} / 1$

$0.3 \mu \mathrm{g} / 1$
$0.002 \mu \mathrm{g} / \mathrm{I}$
$0.05 \mu \mathrm{g} / 1$
$0.01 \mu \mathrm{g} / 1$
$0.05 \mu \mathrm{g} / 1$

tissues

$--$
$0.001 \mathrm{mg} / \mathrm{l}$

$0.001 \mu \mathrm{g} / 1$

12 Warm water $\geq 5.0 \mathrm{mg} / \mathrm{l}$ Except $>4.0$ to 5.0 durino. short periods in any $24 \mathrm{hr}$ (does not apply to

hypolimnion 0 E stratified lakes)

2) $>7.0$ for spawning $>6.0$ for growth $5.0-6.0$ short. periods. $4.0^{\circ}$ 5.0 in large streams up to $6 \mathrm{hr}$ 
TABLE $c-2$. (cont)

Parameter Most Critical Use

Foaming

-agents

ABS

LAS

- MBA

NTA
Freshwater

(aquatic life)
Value NAS

EPA

3) 56.0 in hypolimnion $\mathrm{c}$ : oligotrophic lakes.

4) Bottom must be aerobic to suppress botulism organisms

$\begin{array}{ccc}1 / 20 \mathrm{LC}_{50} & 1 / 20 \mathrm{LC}_{50} & 1 / 748 \mathrm{hr} \mathrm{TLm} \text { a: } \\ 0.2 \mathrm{mg} / 1 & 0.2 \mathrm{mg} / 1 & 0.2 \mathrm{mg} / 1 \text { (LAS) } \\ \text { (LAS) } & \text { (LAS) } & 1.0 \mathrm{mg} / 1 \mathrm{ABS}\end{array}$


4. Freshwater (wi ld life)

5. Freshwater (public supply)

6. Marine water (aquatic life)

7. Recreational waters

The most critical use criteria may not match the use criteria of receiving waters for a generic site, but they can be considered the safest criteria for any potential use of the water downstream. This type of consideration may require more pollution control, but it gives a greater margin of safety than just meeting receiving water criteria. For example, the concentration of a parameter may be totally acceptable when used for human consumption, but at the same concentration may be toxic to plants. By using the agriculture irrigation criteria, which in this case is the most critical use, instead of freshwater public supply criteria, the potential toxic effect on plants is eliminated and the effluent is potentially safer for all uses.

\section{TOXICOLOGY DATA}

Human toxicity data are not available for all chemicals. A more standard toxicity reference is the $L D_{50}$ for rats. $L_{50}$ is the lethal dose $(\mathrm{mg} / \mathrm{kg}$ ) which kills $50 \%$ of the rats. If $L_{50}$ are not available, then TLm data may be used to indicate concentrations which are potentially hazardous. TLm is the limit where an effect is first noted. It is difficult to infer the potential toxicity of an ion group because toxicity data are usually reported on a pure compound basis.

ENVIRONMENTAL STANDARDS FOR CHEMICAL EFFLUENTS FROM NUCLEAR FUEL CYCLE FACILITIES

The plants or processes of the nuclear fuel cycle that are currently regulated are:

1. Uranium mining; both open pit and underground

2. Uranium milling; acid leach and acid/alkaline leach mills

3. Steam electric power generating plants. 
The other steps in the nuclear fuel cycle are not directly regulated. However, parts of the processes can be matched with effluent guidelines for industries with similar processes. Although the guidelines do not specifically refer to a nuclear fuel cycle plant, these standards should be considered effluent levels that are acceptable.

The sources most amenable to current guidelines are: (1) fluoride production wastes, which are generated in indirect conversion plants, and subsequently up the fuel chain; and (2) ammonia, which is generated and wasted throughout the fuel cycle. The guidelines specify no release of fluorides into navigable waters from production of fluoride from HF-Salt electrolysis. The fluorides emitted will be carefully monitored so as not to exceed water quality limits.

The fluorine production subcategory is concerned with manufacture of fluorine by the liquid hydroflouric acid electrolysis process. The standard reads that there shail be no discharge of process wastewater poliutants to navigable waters. This fluoride guideline will be of help in any of the processes that generate fluorine for processing uranium oxide, i.e., conversion facilities.

It is harder to determine criteria for ammonia based on the guidelines from the Federal Register which are specified for ammonia plants. Ammonia releases are specifically limited, and it is probable that ammonia will be controlled in the future in fuel cycle plants.

The ammonia subcategory of the fertilizer industry can apply to processes that use and release large categories of $\mathrm{NH}_{3}$ to the environment. The $\mathrm{UO}_{2}$ fuel fabrication facilities emit large quantities of ammonia, hence the guideline for ammonia release is as follows:

$\begin{array}{lllll}\text { Ammonia (as } N) & \frac{\text { Monthly }}{\text { BPCTCA }} & \frac{\text { Daily }}{\text { Monthly }} & \text { BATEA } \\ \begin{array}{l}\mathrm{Kg} / \mathrm{KKg}(1 \mathrm{~b} / 1000) \\ \text { of Product }\end{array} & 0.0625 & 0.125 & 0.025 & 0.05\end{array}$


The nickel plating in the fuel fabrication plant can be compared with the electroplating industry which has been regulated for the common metal platers. It would be possible to eliminate most of the parameters listed if it could be established that the chemicals are not used within the plating operation. Tables $\mathrm{C}-3$ and $\mathrm{C}-4$ show the standards for electroplating operation.

Nitric acid used throughout the fuel cycle processes will also be a "red flag" chemical because of the prospect of excessive emissions of nitrate ions.

Tables C-5 through $\mathrm{C}-13$ match the existing environmental standards with the chemical effluents for each facility. Wherever possible, emission standards for similar processes have been identified. Water quality criteria and toxicology data are also included for each chemical species.

\section{FUTURE ENVIRONMENTAL STANDARDS FOR NUCLEAR FUEL CYCLE FACILITIES}

The national goal of zero discharge looms in the future, and eventually no pollutants will be allowed to enter water courses from industrial sources. The Toxic Substances Act which was enacted in 1976 may also affect release rates of any chemicals deemed toxic now and in the future. 
TABLE C-3. BPCTCA Guideline for Electroplating

\begin{tabular}{|c|c|c|}
\hline Effluent & $\begin{array}{r}\text { Max. } \\
\left(\mathrm{mg} / \mathrm{m}^{2} \text { of op operation }\right) \\
\end{array}$ & $\begin{array}{l}\text { Average Daily } \\
\text { Values for } 30 \text { Days }\end{array}$ \\
\hline Copper & 160 & 80 \\
\hline Nicker & 160 & 80 \\
\hline Cr Total & 160 & 80 \\
\hline $\operatorname{cr}(V I)$ & 16 & 8 \\
\hline Zinc & 160 & 80 \\
\hline CN, Total & 160 & 80 \\
\hline $\mathrm{Cn}, \mathrm{A}$ & 16 & 8 \\
\hline Fluoride & 6,400 & 3,200 \\
\hline Cadmium & 96 & 48 \\
\hline Lead & 160 & 80 \\
\hline Iron & 320 & 160 \\
\hline Tin & 320 & 160 \\
\hline Phosphorous & 320 & 160 \\
\hline TSS & 6,400 & 3,200 \\
\hline $\mathrm{pH}$ & $\begin{array}{r}\text { within } \\
6-9.5\end{array}$ & within 6-9.5 \\
\hline
\end{tabular}


TABLE C-4. BATCA Guidelines for Electroplating

Effluent

Copper

Nickel

Cr Total

Cr, VI

Zinc

CN, Total

CN, A

Fluoride

Cadni im

Lead

Iron

Tin

Phosphorous

TSS

$\mathrm{pH}$
Max; 1 Day Value (mg/m of operation)

80

80

80

8

80

80

8

3200

48

80

160

160

160

3200

within 6 to 9.5
Average Daily Values for 30 Consecutive Days Shall Not Exceed

40

40

40

4

40

40

4

1600

24

40

80

80

80

1600

within 6.0-9.5 


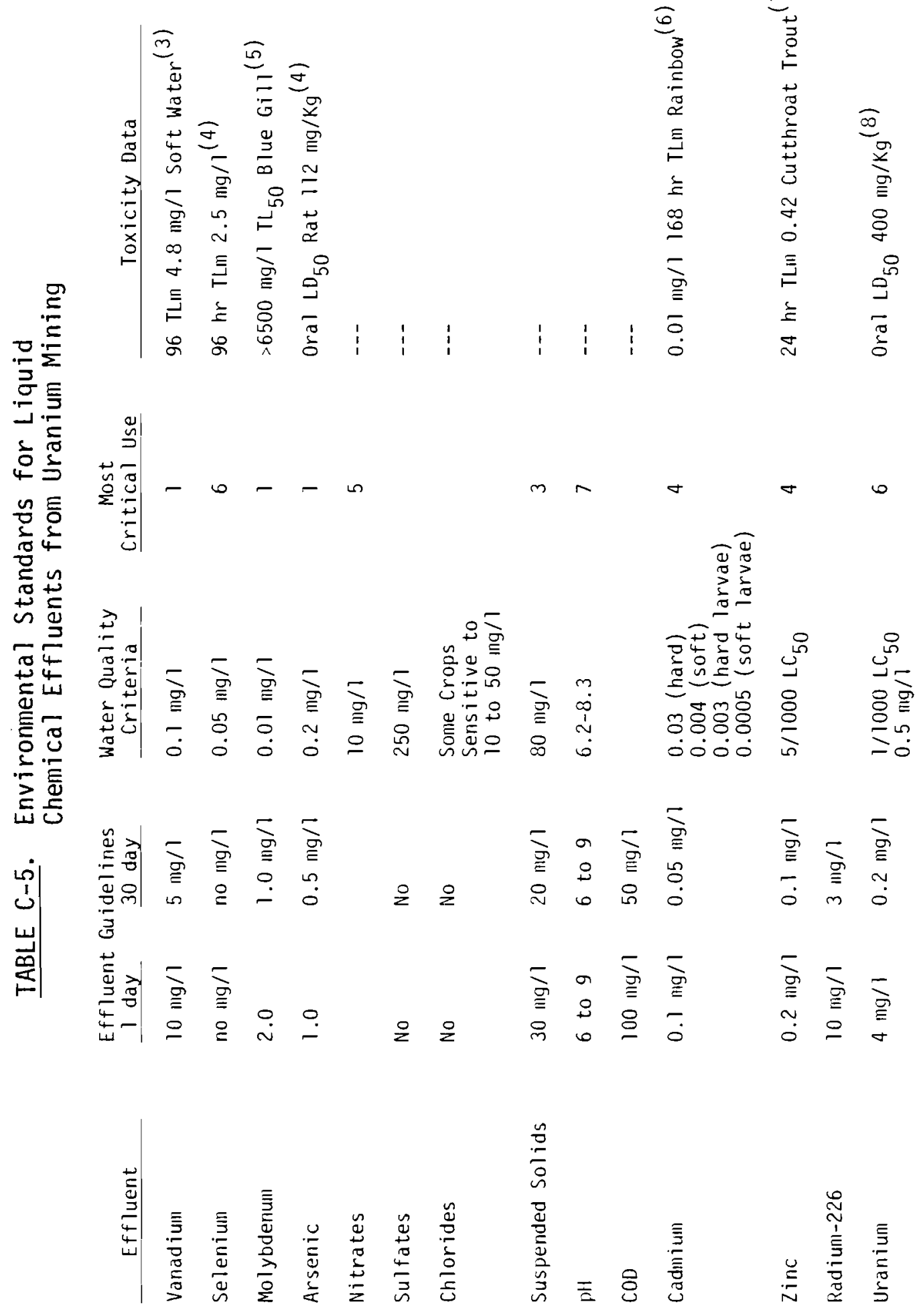




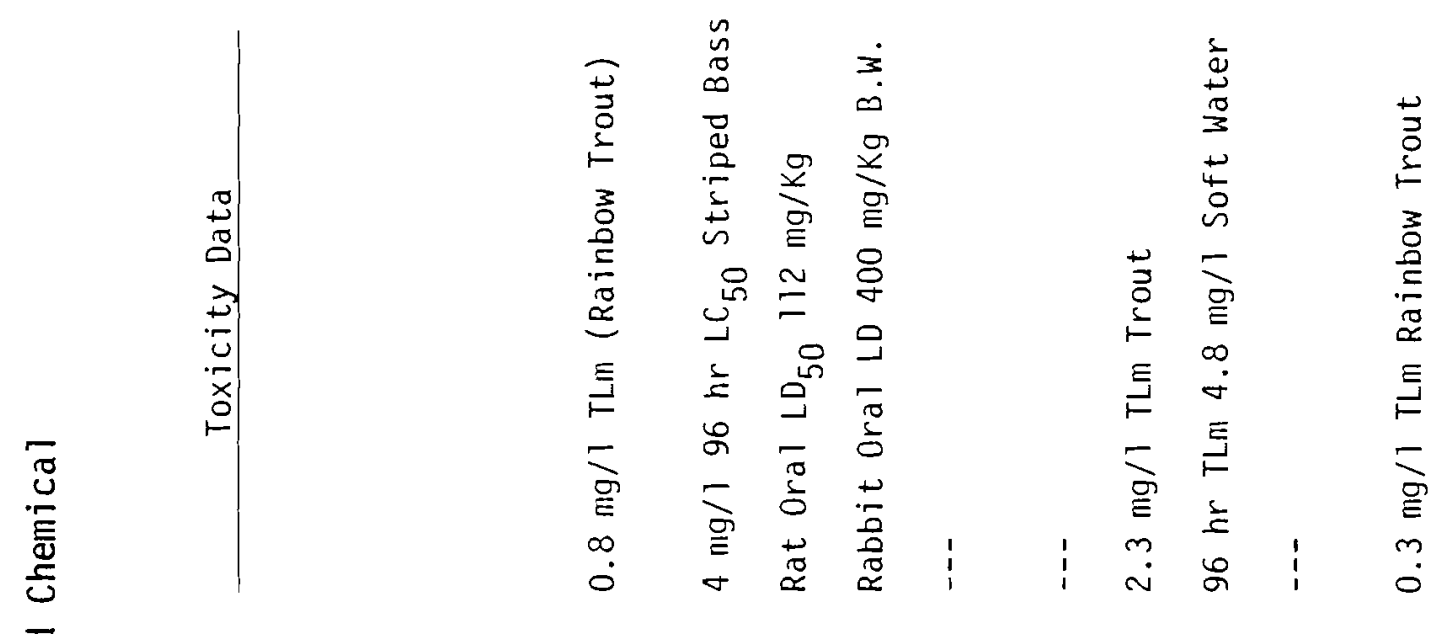

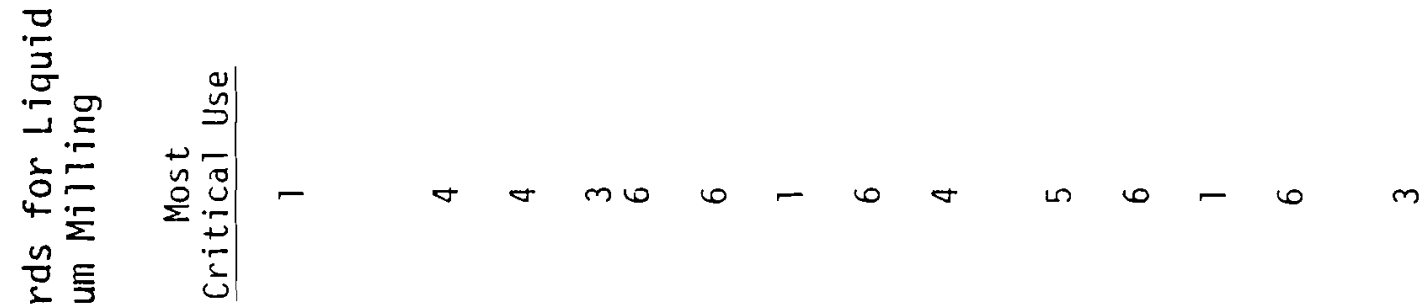

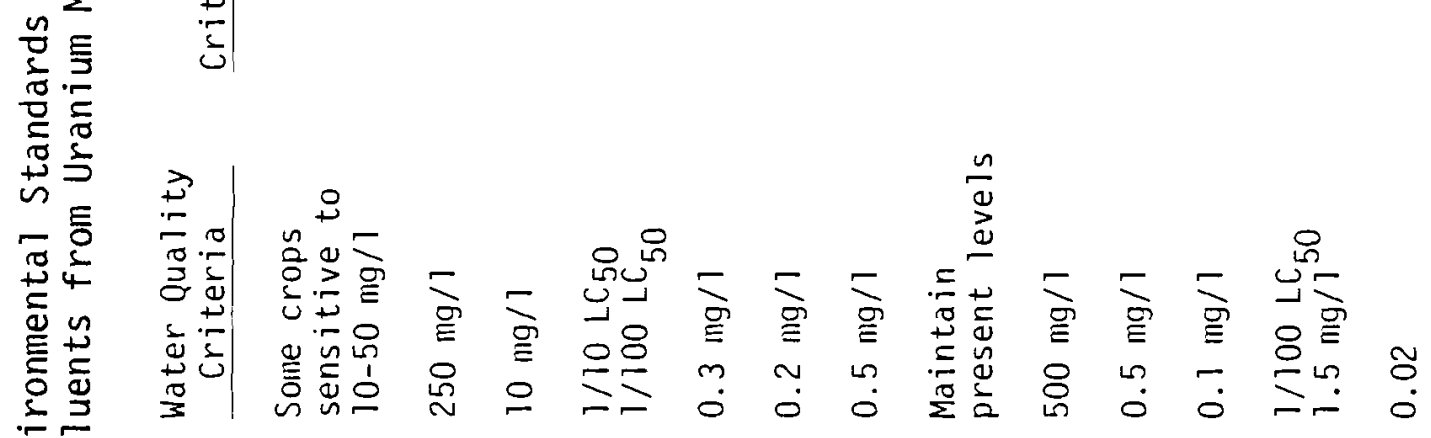

糨

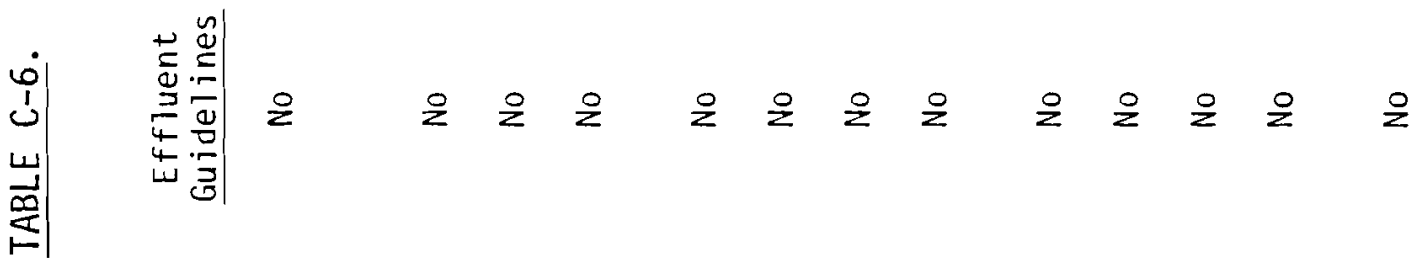

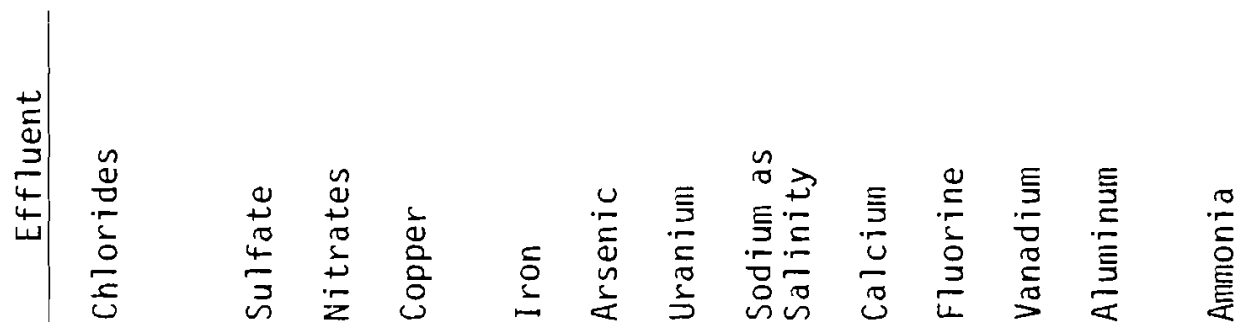




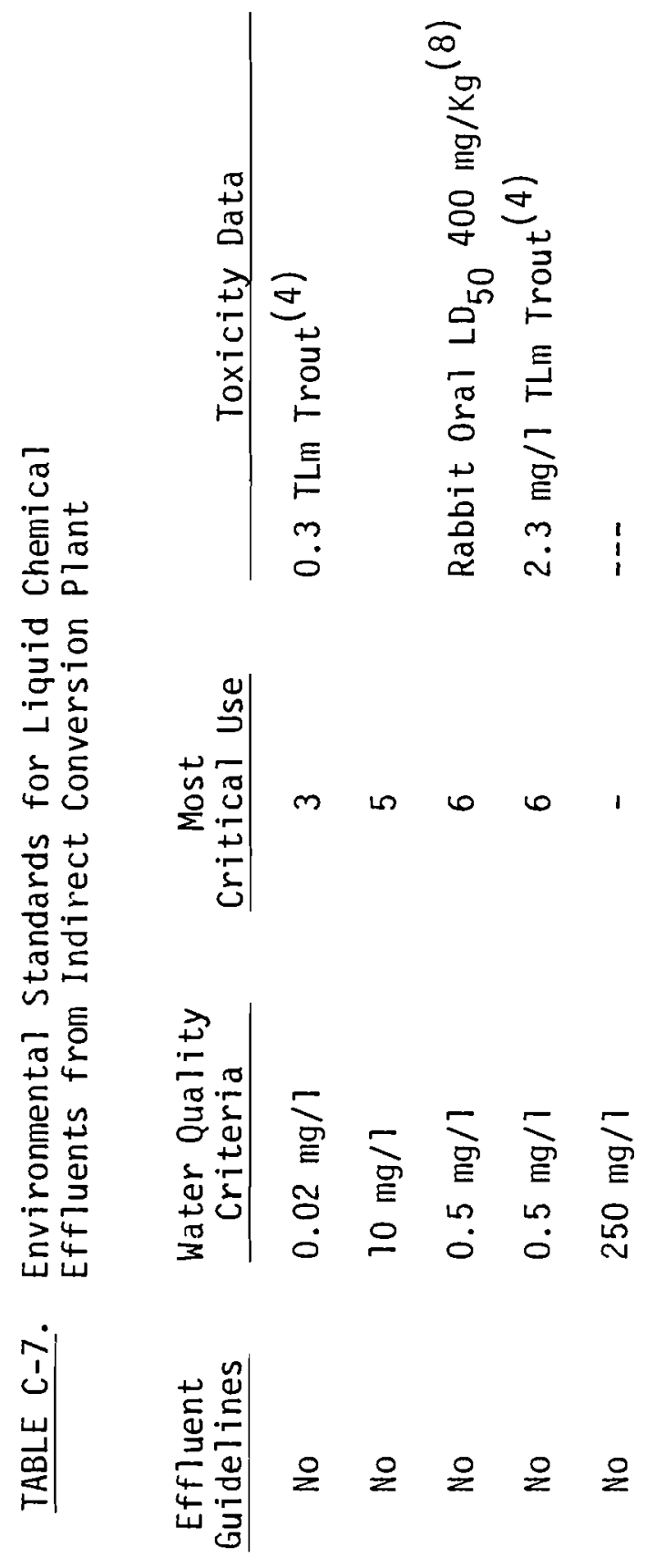

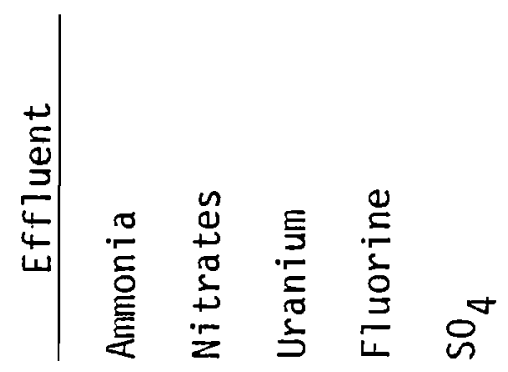




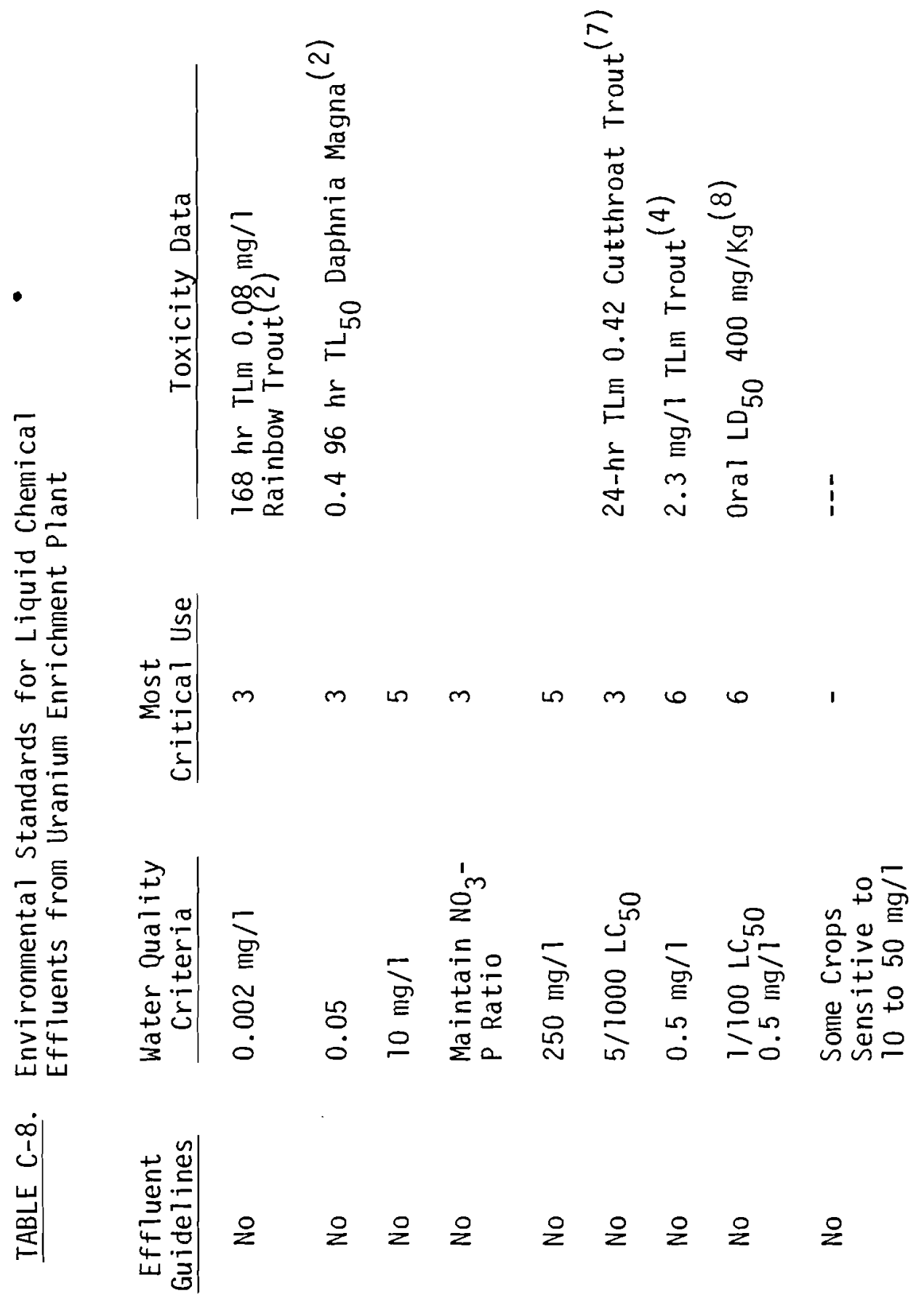

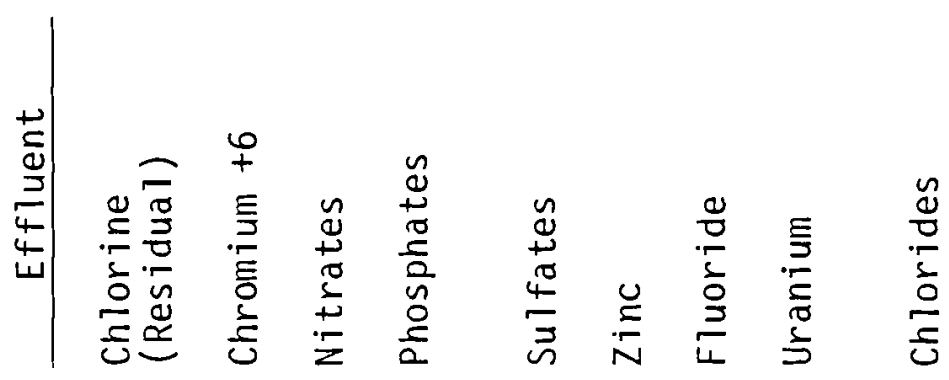




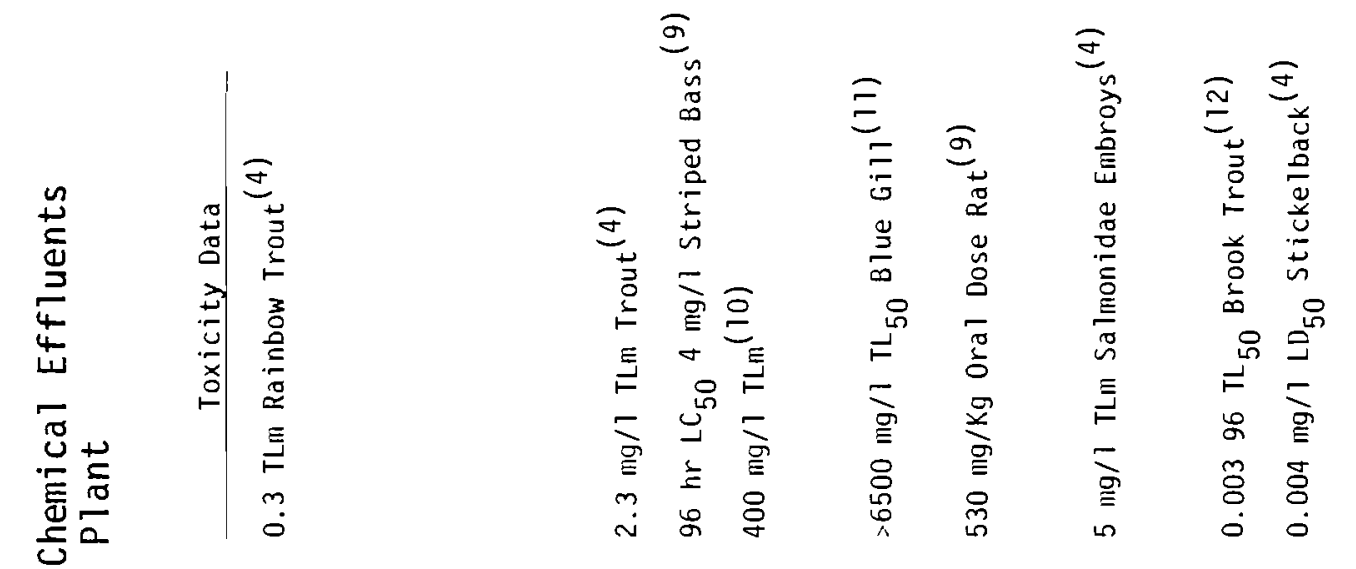

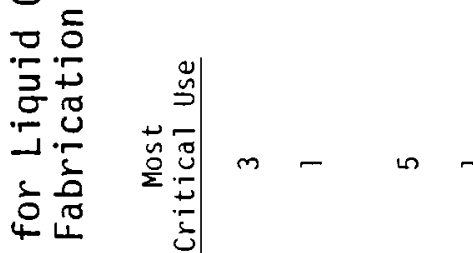

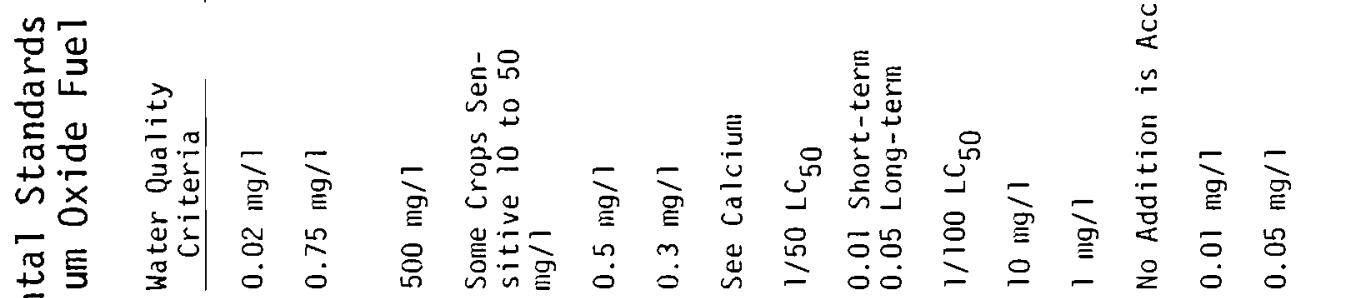

离䆑

동

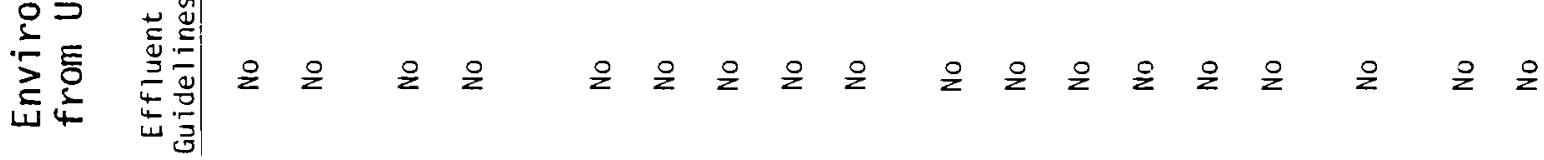

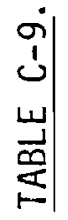

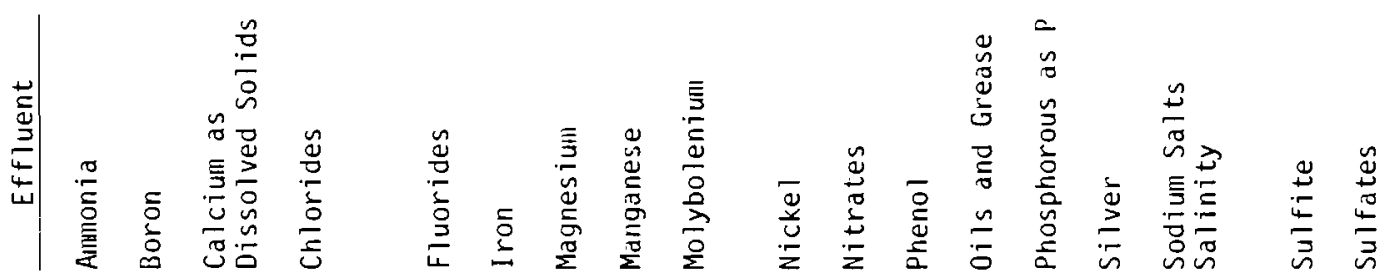




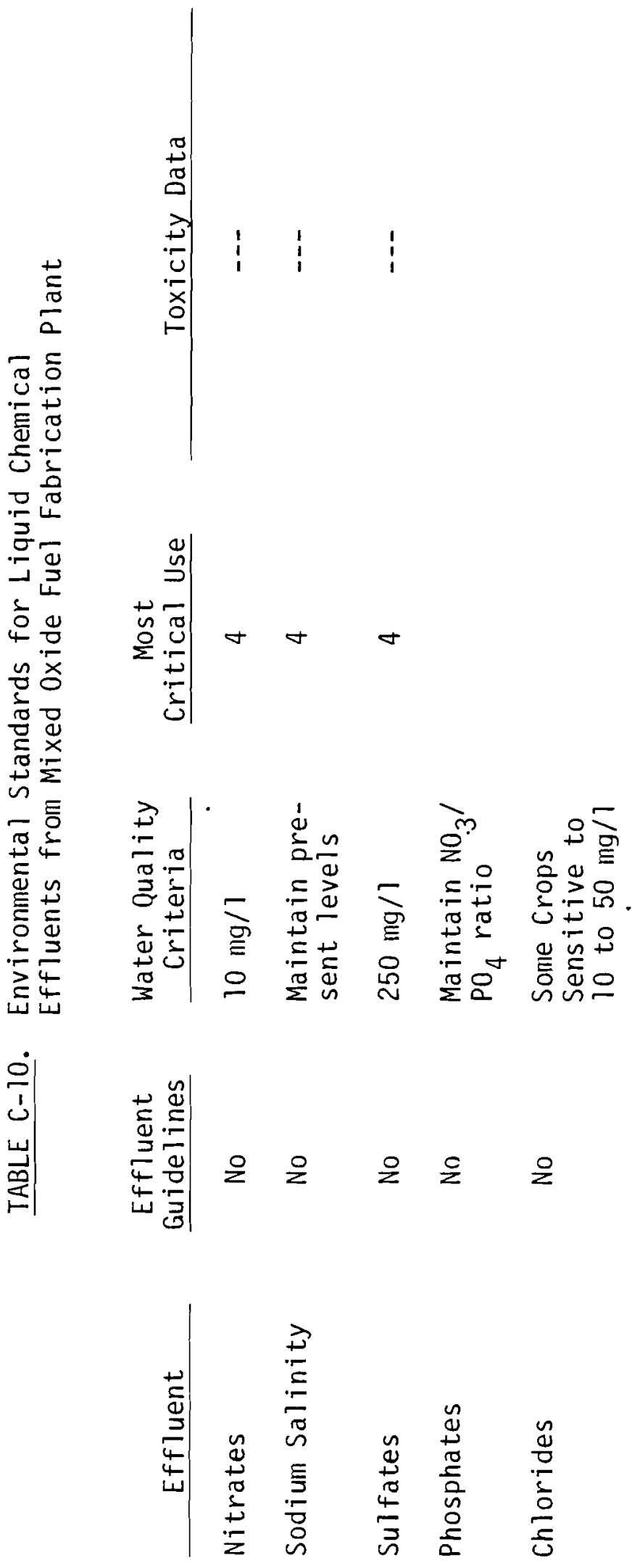




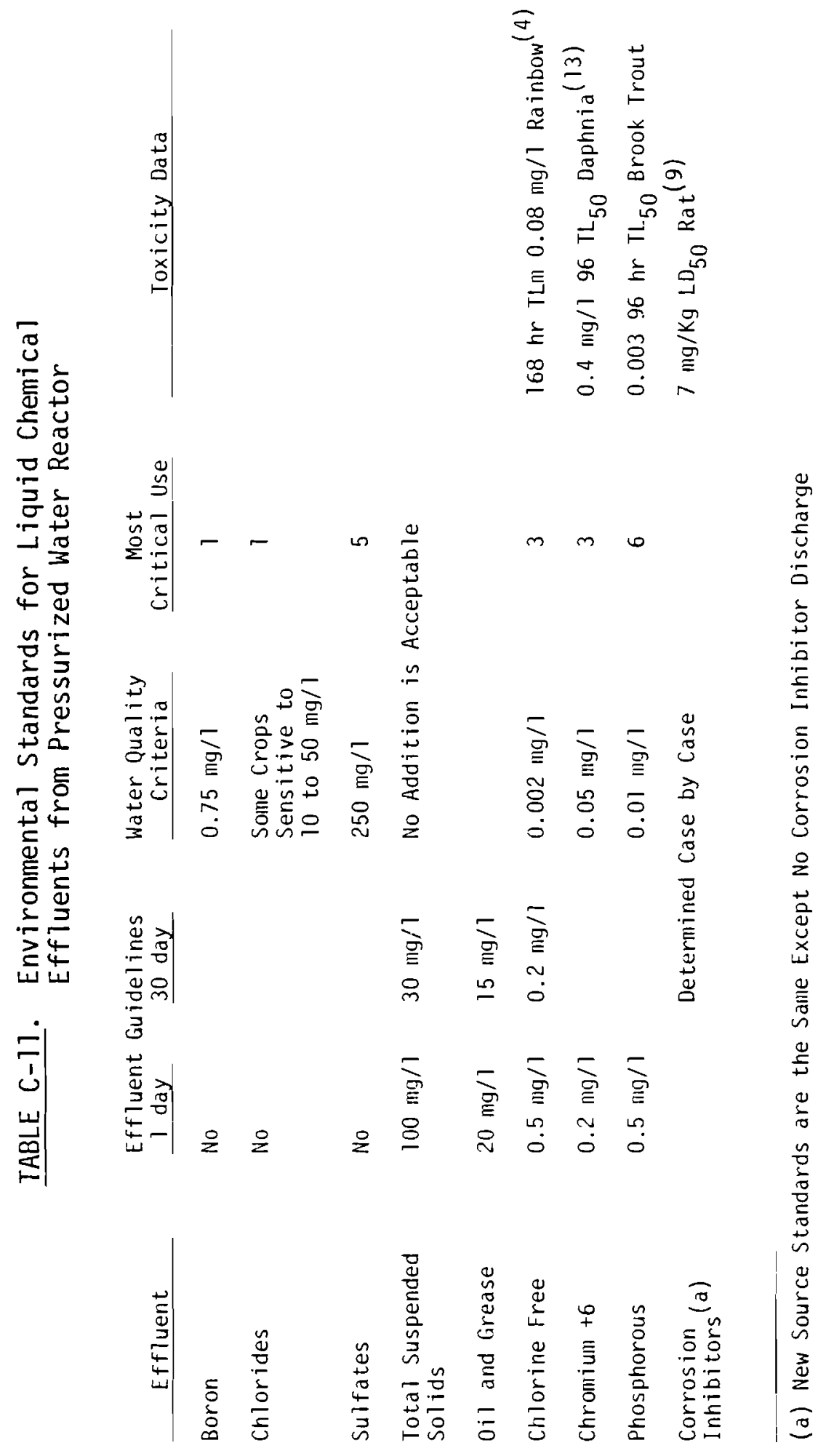




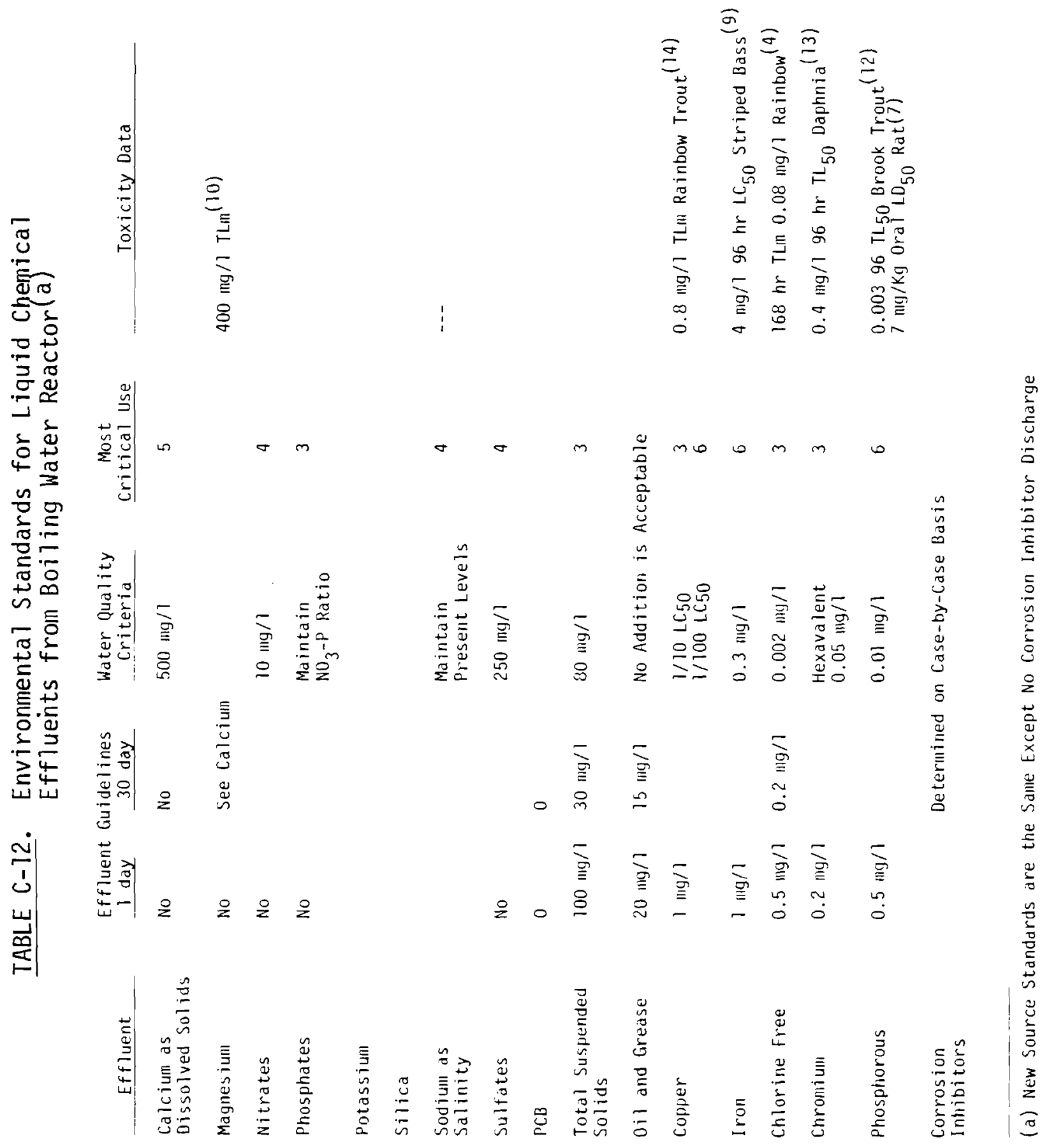




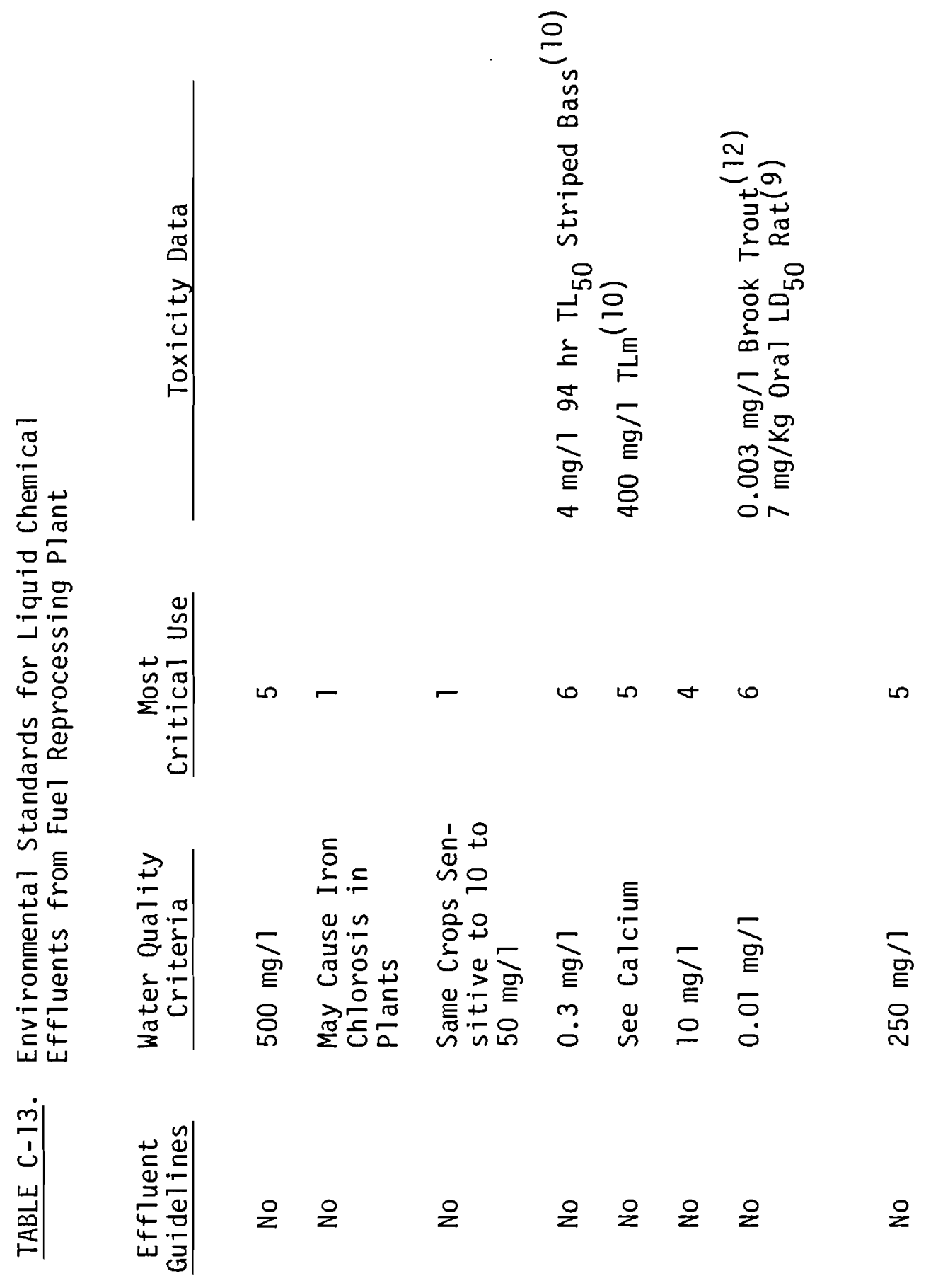

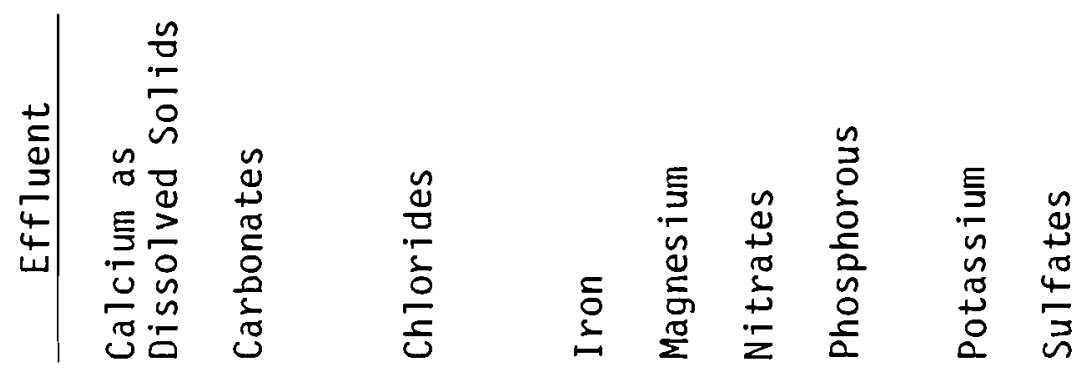




\section{REFERENCES}

1. Developmental Document for Interim Final and Proposed Effluent Limitations Guidelines and New Source Performance Standards for the Ore Mining and Dressing Industry Point Source Category, Vol. 1, EPA 440/1-75/061, 1975.

2. Spector, W. S., Handbook of Toxicology, V01. 1 \& 2, Philadelphia, Pennsylvania, $19 \overline{56 .}$

3. Tarzwe11, C. W. and C. Henderson, "Toxicity of Less Common Metals to Fishes," Ind. Wastes, Vo1. 5, p. 12.

4. McKee, J. E. and H.W. Wolf, "Water Quality Criteria," USPHS, HEW, The Resources Agency of California, State Water Resources Control Board, Pub. 3-A, Apri1 1971.

5. "Perspective," Industrial Water Engineering, May/June 1974.

6. "The Toxicity of Cadmium to Rainbow Trout (Salmo Gairdneni Richardson)," Water Res., Vol. 1, pp. 805-806.

7 Rabe, R. W. and C.W. Sappington, "Biological Productivity of the Cour D'Alene River as Related to Water Quality (The Acute Toxicity of Zinc to Cutthroat Trout Salmo Clarki)," Idaho Water Resource Research Institute Completion Report, 1970.

8. Water Quality Data Book - Vol. 2, Arthur D. Little, Inc., Environmental Protection Agency Contract No. 14-12-538, 18010DPV, Ju1y 1971.

9. Stecher, P. G. (Ed.), Merck Index, 8th Edision, Merck and Company, Rahway, New Jersey, 1968.

10. Klein, L., Aspects of River Pollution, Academic Press Inc., New York.

11. J. Ind. Hygiene Tox., Cambridge, Massachusetts, Vo1. 31, p. 343, 1949.

12. Fletcher, G. L., R. J. Hoyle and D. A. Horne, "Yellow Phosphorous Pollution: Its Toxicity to Seawater Maintained Brook Trout (Salvelinus Fontinalis) and Smelt (Osmerus Mordax)," J. Fish Res. Bd. Canada, Vol. 27 , No. 8, 1970.

13. Dowden, B. F. and H. J. Bennett, "Toxicity of Selected Chemicals to Certain Anima1s," JWPCF, Vol. 37, No. 9, pp. 1308-1316, 1965.

14. Herbert, D.W., D. H. M. Jordan, and R. Lloyd, "A Study of Some Fishless Rivers in the Industrial Midlands," J. Proc. Institute Sewage Prof., London, 1965. 
APPENDIX D

REVIEW OF ENVIRONMENTAL ASSESSMENT METHODOLOGIES 

APPENDIX D

\section{REVIEW OF ENVIRONMENTAL ASSESSMENT METHODOLOGIES}

This appendix identifies a large body of work on the development and use of environmental assessment methodologies. These references were used to develop a method for assessing chemical effluents from the nuclear fuel cycle. Environmental assessment methods have three main purposes which vary mainiy in scope and point of application:

- To assess the potential hazard of specific pollutants

- To assess the total environmental impact from one facility or technology

- To develop information and provide a basis for selecting one energy technology over another one.

The following material emphasizes the methodology used, not the results obtained. The investigator's results are given only if they reveal some perspective on the methodology itself.

\section{POTENTIAL HAZARD ASSESSMENT METHODS}

Environmental standards are set to protect human health and welfare. Assessment studies provide the basis for setting such standards. Many studies have been made on specific chemicals. $(1-5)$ These studies assess the sources, ambient exposure, biological effects, and available control technology. The assessment work compiles what is known and reported in the literature.

Although there is a vast data base on the effects of specific chemicals on test animals and on the occupational exposure to chemicals, the epidemiological data base is still very meager. Work by EPA $(6)$ is in progress to provide the necessary information to set and defend environmental standards. The purpose of the EPA work is to provide dose-response information relating short-term and long-term pollutant exposures to adverse health effects. 


\section{ENVIRONMENTAL IMPACT ASSESSMENT METHODS}

The 1969 Nationa1 Environmental Policy Act (Public Law 91-190) requires environmenta 1 impact assessments to be made for a wide range of federa 1 programs and activities. For example, it is under this law that the NRC is required to write an environmental impact statement for every nuclear power plant it licenses. Specifically the act requires agencies of the federal government to "identify and develop methods and procedures which will insure that presently unquantified environmental amenities and values are given appropriate consideration in decision-making along with economic and technical considerations." Hence this act attempts to include the detrimental effects of any facility or technology in any overall benefit-cost analyses. Past traditional benefit-cost analyses have focused primarily on income benefits and direct project costs, giving only a token recognition to the social and environmenta 1 consequences.

Leopold ${ }^{(7)}$ presents an open-ce11 matrix chart for identifying 100 project activities and 88 environmental conditions. For each action in the project, the magnitude and significance of the environmental impact is subjectively evaluated. The approach was not developed in reference to any specific type of project. Leopold does not present guidelines for using this approach and therefore reduces the replicability of the method. The main value of the method is identifying impacts and communicating these results to others.

Bender and Ahmed ${ }^{(8)}$ have presented a semiquantitative approach for evaluating the overall impact of electric power generating plants. An index of Composite Environment (ICE) is defined mathematically as follows:

$$
I C E_{j}=\sum_{k=1}^{n} D C_{k, j} C V_{k, j}\left(\frac{1000}{I C E_{0}}\right) \text {, }
$$


where

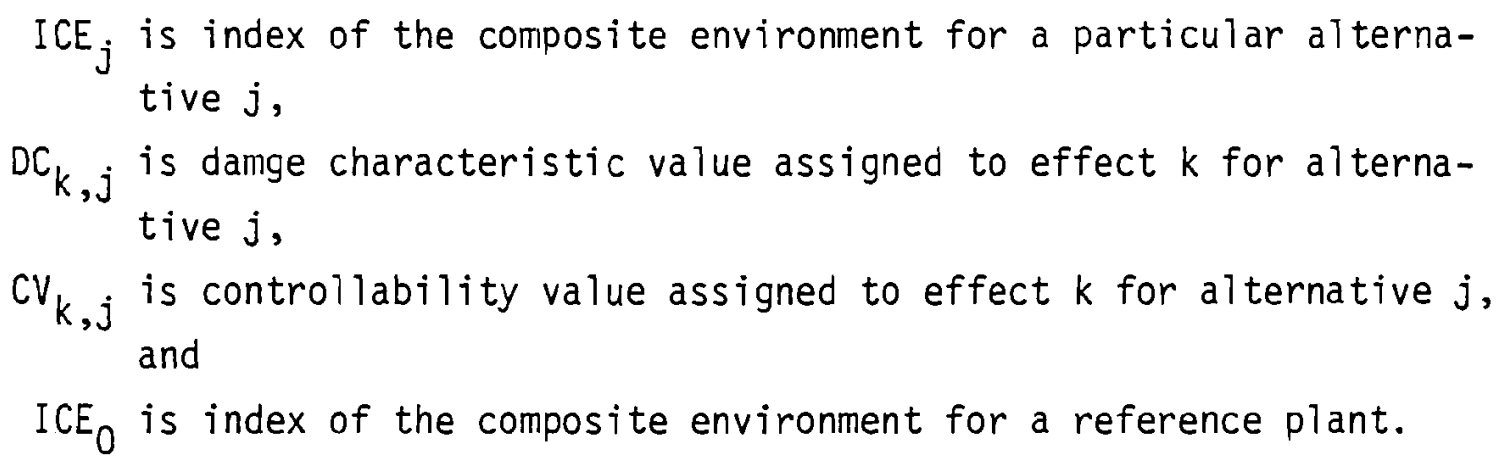

The damage potential is identified by a damage characteristic, DC, value range from 0.0 to 1.0 ; the upper value being that associated with the worst conceivable environmental effect. The controllability value, $C V$, ranges from 0.0 to 20 . The highest value of 20 indicates that nothing can be done to control the effect. Since ICE is the product of DC and CV, alternatives with high ICE values are less desirable.

Computation of the ICE results in a set of values can be used:

- To provide an overall comparison of the environmental impact of a specific energy system on a specific site with a reference system and site of recognized environmental quality,

- To show the distribution of impact factors affected by damage characteristics (DC) and controllability values (CV),

- To identify each effect separately for the purpose of determining whether it satisfies the environmental constraints of the ICE,

- To show whether the environmental effects are properly balanced so that they will be fairly distributed with respect to recipients of environmental damage and beneficiaries of energy systems without undesirable concentrations of effects on one portion of the environment, and

- To permit the comparison of several sites and energy systems on an itemby-item basis with respect to environmental effects. 
This approach uses the knowledge of environmental specialists to quantify the anticipated damage potential or characteristics $(D C)$ related to the environmental effects of a specific energy system on a specific geographical site. Controllability values ( $\mathrm{CV}$ ) for these effects are then assigned by considering the technological alternatives that could ameliorate environmental damage. Certain constraints must be satisfied to assure a realistic environmental assessment. Local or site-related constraints are established by the permissible level of each controllability value in combination with an assigned damage characteristic. Thus, the ICE is a measure of damage potential (DC) and damage control (CV) summed for the 1 isted environment effects.

The derived ICE will reflect conformance with regulatory limits through application of the local or site-related constraints and, where appropriate, the degree to which environmental damage is lessened beyond regulatory limits. Comparisons are made with an arbitrarily defined reference basis (ICE ${ }_{0}$ ) that provides a standard against which each environmental effect can be judged.

Warner and Preston ${ }^{(9)}$ reviewed 17 methodologies and evaluated their strengths, weaknesses and ranges of applicability for use with NEPA. They evaluated the methodologies on the basis of their ability to deal with four key problems: impact identification, impact measurement, impact interpretation and impact communication to information users. They concluded that there is no single "best" methodology for environmental impact assessment. Only the user can determine which method may best fit the specific requirements. The various methodologies evaluated can be divided into five categories, based on the way impacts are identified:

1. Ad hoc: These methodologies provide minimal guidance to impact assessment beyond suggesting broad areas of possible impacts (e.g., impacts on flora and fauna, impacts on lakes, forests, etc.), rather than defining specific parameters to be investigated.

2. Overlays: These methodologies rely on a set of maps of environmental characteristics (physical, social, ecological, aesthetic) for a project area. These maps have overlays to produce a composite 
characterization of the regional environment. Impacts are identified by noting the impacted environmental characteristics lying within the project boundaries.

3. Checklists: These methodologies present a specific list of environmental parameters to be investigated for possible impacts but do not require establishment of direct cause-effect links to project activities. They may or may not include guidelines on how parameter data are to be measured and interpreted.

4. Matrices: These methodologies incorporate a list of project activities in addition to a checklist of potentially impacted environmental characteristics. These two lists are related in a matrix which identifies cause-effect relationships between specific activities and impacts. Matrix methodologies may specify which actions impact which environmental characteristics or may simply list the range of possible actions and characteristics in an open matrix to be completed by the analyst.

5. Networks: These methodologies work from a list of project activities to establish cause-condition-effect networks. They are an attempt to recognize that a series of impacts may be triggered by a project action. These approaches generally define a set of possible networks and allow the user to identify impacts by selecting and tracing out the appropriate project actions.

Whitman et al. (10) proposed an environmental evaluation system (EES) to the Bureau of Reclamation for evaluating the impact of its water projects. The EES is based upon a hierarchical arrangement of critical environmental quality parameters arranged in four major categories and 17 subcategories (components).

\section{ECOLOGY (315)}

A. Species and Populations (144)

B. Habitats and Communities (196)

C. Ecosystems (75)
II. ENVIRONMENTAL POLLUTION (321)

D. Water Poliution (160)

E. Air Pollution (40)

F. Land Pollution (93)

G. Noise Pollution (28) 
III. AESTHETICS (159)

H. Land (25)

I. Air (11)

J. Water (39)

K. Biota (28)

L. Man-made Objects (21)

M. Composition (35)
IV. HUMAN INTEREST (205)

N. Educational-Scientific Significance (64)

0. Historical Significance (55)

P. Cultural Significance (54)

Q. Mood-Atmosphere Significance (32)

Relative values (in parenthesis above) of the environmental effects associated with each environmental category, component, and parameter were assigned to provide a weighting system of environmental impacts, adding up to a total of 1000 environmental quality units (EQU). The project with the highest number of EQU is the best alternative. The relative values were selected by Battelle personnel. They recommend that actual relative values should be determined by a cross-section of society and not a small segment or special interest group. They therefore proposed a method for making this determination.

Fennelly et al. (11) have outlined the considerations involved in making environmental assessments for energy technologies. Their objectives were to:

- Define environmental assessment programs and their role in energy system deveropment

- Indicate the data requirements of an environmental assessment

- Outline exemplary methodologies for acquiring the necessary data

- Serve as a technology transfer vehicle by providing background information on both conventional and state-of-the-art techniques in environmental monitoring and modeling which can be used in environmental assessments

- Summarize the extent, quality, applicability, and location of existing information resources

- Summarize existing or proposed standards and criteria for evaluating air, water, and land based pollution. 
Thus their work was aimed primarily at defining the scope of environmental assessment work required for energy technologies. It does not outline a unique or preferred way to make calculations or conduct such an evaluation program. The report is not specifically designed for the preparation of environmental impact statements.

Eimutis $^{(2)}$ and Eimutis et al. (13) have developed and applied a model for the ranking of stationary air pollution sources. The purpose of the work is to determine which sources should be further evaluated for possible application of air pollution control equipment. The ranking is determined by computing a relative environmental impact for each type of source. The potential environmental impact of a source is determined from the source severity, SV, defined as the product of the degree of hazard and the population density. The degree of hazard is defined as the ground level concentration contribution of pollutants relative to some potentially hazardous concentration of the same species. The degree of hazard of the $i^{\text {th }}$ material in the region around the $j^{\text {th }}$ source is expressed

$$
\text { Degree of Hazard }=\frac{\bar{X}_{i j}}{F_{i}}
$$

where

$\bar{x}_{i j}$ is the average concentration of material $i$ from source $j$, and $F_{i}$ is ambient air standard for material $i$.

If a material does not have an ambient air quality standard, then the following expression is used to calculate a value for $F$ :

$$
F_{i}=T L V_{i}\left(\frac{8}{24}\right)\left(\frac{1}{100}\right)
$$

where

$T_{L V}$ is the Threshold Limit Value for material $i$, $\frac{8}{24}$ is a factor to adjust the TLV from an $8-h r$ to a $24-h r$ time period, and $\frac{1}{100}$ is a factor of safety. 
The source severity, SV, is calculated as follows:

$$
S V_{i j}=P_{j} \frac{\bar{X}_{i j}}{F_{i}}
$$

where

$S V_{i j}$ is the severity imposed on individuals by the $i^{\text {th }}$ material from the $j^{\text {th }}$ source, and

$P_{j}$ is the population density around source $j$.

The impact factor, $I_{x}$, associated with a given source type $x$ is defined to be the sum of the lengths of the individual severity vectors associated with the point sources within the source type. Thus:

where

$$
I_{x}=\sum_{j=1}^{K_{x}} P_{j}\left[\sum_{i=1}^{N}\left(\frac{\bar{x}_{i j}}{F_{i}}\right)^{2} \frac{\bar{x}_{i j}^{1}}{S_{i}}\right]^{1 / 2}
$$

$I_{x}$ is impact factor, persons $/ \mathrm{km}^{2}$,

$k_{x}$ is number of sources emitting materials associated with source type $x$,

$N$ is number of materials emitted by each source

$P_{j}$ is population density in the region associated with the $j$ th source, persons $/ \mathrm{km}^{2}$,

$\bar{x}_{i j}$ is calculated maximum ground level concentration of the $i \frac{\text { th }}{\text { material }}$

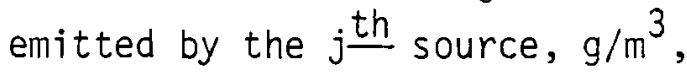

$F_{i}$ is environmental hazard potential factor of the $i$ th material, $\mathrm{g} / \mathrm{m}^{3}$, $X^{\prime}{ }{ }^{j} j$ is ambient concentration of the $i \frac{\text { th }}{}$ material in the region associated with the $j$ th source, and

$S_{j}$ is corresponding standard for the $i \frac{\text { th }}{\text { material. }}$. 
The impact factor is the parmeter Eimutis used to rank-order the categories of stationary air pollution sources.

Handy and Schindler (14) have developed a methodology for estimating maximum permissible continuous exposure levels for air and water pollutants. EPA has set maximum concentration exposure levels for some environmental pollutants. However, there are many known toxic materials for which no safe concentration levels have been established. The main objective of Handy and Schindler was to derive pollutant hazard criteria for these compounds so that safe, permissible concentrations in the environment might be estimated. The recommended equations are subject to the following assumptions and limitations:

1. The presented methods of estimating permissible air and drinking water concentrations do not apply to pollutants with known carcinogenic, teratogenic, or nutagenic effects.

2. The biological treatment was based on a one-compartment model with a single, first order excretion rate.

3. It was assumed that all pollutants entering the respiratory system were retained by the body.

4. The treatment was based on the assumption that $L D_{50}$ values for animals were applicable to man.

5. No allowance was made for synergistec or antagonistic effects of pollutants in multicomponent systems.

6. The derived equations are directly applicable only when the halflife of the pollutant is relatively short compared to the assumed life of the individual.

7. This method does not take into account other sources of environmental contamination. No allowance has been made for pollutant uptake in diet.

8. No allowance was made for metabolic inhibition or induction effects on pollutants in the body.

9. No allowance was made for factors such as odor and taste which may necessarily lower the standard below the maximum safe concentration 7 imit. 


\section{Equations for Ambient Air}

\section{Case I - TLV ${ }^{(a)}$ urknown, $L_{50}$ known}

This case will be encountered most often. The oral $L_{50}(\mathrm{mg} / \mathrm{kg})$ for rats should be used if known. It may be necessary to use the oral $L_{50}$ for mice. The permissible ambient air concentration, $x_{p}\left(\mathrm{mg} / \mathrm{m}^{3}\right)$, is given by the following equation:

$$
X_{p}=4.77 \times 10^{-5}\left(L D_{50}\right)
$$

Case II - TLV known, $L D_{50}$ unknown

This a less common situation. A derived $L_{50}$ is computed from the equation,

$$
L D_{50}=34.5 \mathrm{TLV}
$$

and used directiy in the expression given in Case I.

Alternatively, the following equivalent equation may be used:

$$
x_{p}=1.65 \times 10^{-3} \text { (TLV) }
$$

Case III - TLV and $L D_{50}$ known

Use the TLV and proceed as in Case II.

(a) The TLV is the acceptable concentration for $8 \mathrm{hr} /$ day, $40 \mathrm{hr} /$ week exposure without any adverse health effects to a heal thy worker. The TLV values are set by the American Conference of Governmental Industrial Hygienists.

The LD50 or median lethal dose represents the dose level which is lethal to half of the test population. Hence if ten rats are fed this dose, five will die over the 14-day observation period. The dose itself is applied during a 24-hr period and is measured in terms of mg of materials per $\mathrm{kg}$ body weight. Oral doses to rats are the most common data available. 
Case IV - TLV unknown, $L D_{50}$ and biological half-life for man known

This case will not be encountered often since the half-lives of most compounds in man are not known. However, the equations do provide for taking this into consideration if the information is available:

$$
x_{p}=\frac{\left(14.2 \times 10^{-4}\right)(L D 50)}{\tau}
$$

where $\tau$ is the biological half-life in days.

Equations for Drinking Water

Case I - TLV unknown, $L D_{50}$ known

For inorganic compounds, the ionic $L D_{50}$ for ion consideration is computed from the $L D_{50}$ for the compound. The ionic $L D_{50}$ is defined as:

Ionic $L D_{50}=\frac{\left.\text { (Compound } L D_{50}\right)(\% \text { content of metal or anion) }}{100}$

a. For most organic and inorganic compounds, excluding those that are known to be retained in the body for prolonged periods of time, the permissible concentration, $x_{e}(\mathrm{mg} / \mathrm{l})$, is

$$
x_{e}=4.0 \times 10^{-4}\left(L_{50}\right)
$$

b. For those compounds known to be retained by the body for long periods of time, use the equation:

$$
x_{e}=3.3 \times 10^{-5}\left(L D_{50}\right)
$$

Case II - TLV known, $L D_{50}$ unknown

A derived $L D_{50}$ is computed from the equation,

$$
\mathrm{LD}_{50}=34.5 \mathrm{TLV}
$$


and used directly in the appropriate expression given in Case I. The equivalent equations for relating TLV directly to $x_{e}$ are shown below.

$$
\begin{aligned}
& \text { a. } x_{e}=1.38 \times 10^{-2} \text { (TLV) } \\
& \text { b. } x_{e}=1.14 \times 10^{-3} \text { (TLV) }
\end{aligned}
$$

Case III - TLV and $L_{50}$ known

Use the TLV and proceed as in Case II.

Case IV - TLV unknown, $L_{50}$ and biological half-life for man known When the $L D_{50}$ and biological half-life, $\tau$, is known, the following equation should be used:

$$
x_{e}=\frac{.012\left(L D_{50}\right)}{\tau}
$$

The ionic $L D_{50}$ is used for inorganic compounds.

\section{TECHNOLOGY ASSESSMENT METHODS}

Several federal programs on energy use are applying technology assessment methodologies. EPA has an "Integrated Assessment Program" and ERDA has a "Regional Studies Program." Both of these programs are aimed at identifying environmentally, socially and economically acceptable energy alternatives.

Whenever there are several alternatives, it is important to rank them with respect to certain criteria. A number of different methods are used to make environmental assessments and comparison of energy technologies. These methods can be categorized according to the criteria used for the comparison: pollutant emission rates, compliance with environmental standards, overal1 risk, environmental impact and economic impact. 


\section{Pollutant Emission Rates}

Eisenbud and Petrow (15), Martin et al. (16), Jaworowski et al. (17), and Hul1 ${ }^{(18)}$ have compared atmospheric pollutant emission rates of various types of power plants. The comparisons are based on the fact that fossil fuels may contain appreciable quantities of radioactive substances which may be emitted in the combustion gases. Coal and oil contain radium-226 and thorium-228, but natural gas contains neither. Thus, Eisenbud and Petrow concluded "Our measurements of the natural radioactivity of fossil fuels have thus led us to the conclusion that an electrical generating station that derives its thermal energy from such fuels discharges relatively greater quantities of radioactive substances into the atmosphere than many power plants that derive their heat from nuclear energy."

Jaworowski et al. ${ }^{(5)}$ reported the following regarding ionizing radiation emissions from coal, BWR and PWR power stations: "... the radiation doses to the general population, being relatively higher in case of fossil fuel power stations and smaller in nuclear ones, are minute enough to be neglected as the health hazard. On the other hand, there is no evidence that nonradioactive pollutants dispersed by conventional power production can similarly be neglected."

Compliance with Environmental Standards

Hul1 $(18,19)$, Terril et al. (20), Schikarski et al. ${ }^{(21)}$ and Starr et al. have used ambient air quality standards as a basis for comparing nuclear and fossil fuel power plants. They have made the comparison by estimating: (a) how well each technology meets its own standards, or (b) how much each would contribute to the degradation of ambient air quality. Thus the environmental standards are used as the common denominator for comparison. Starr et al. (22) used this approach in Los Angeles to answer the question: "How many plants of a given type can be operated without reaching a pollutant concentration having public health significance?" Their answers are shown in Table $0-7$.

Terril et a1. (20) made comparisons in terms of the volumes of air requirec to dilute power plant emissions down to the concentrations specified in ambient air quality standards. The results of this work are shown in Table D-2. Hu17 $(18,19)$ has made a similar study, and he reached the same conclusions as Terril et al. 
TABLE D-1. Tolerable Numbers of Power Plants as Implied by Current Practices in Los Angeles County (a) (22)

Tolerable Numbers of 1,000-Mwe Plants

Critical (Exclusive of Pollutants)

Plant Type Pollutant from Other Sources

$0 i 1$

Natural gas

Nuclear reactor (LWR)
$\mathrm{SO}_{2}$

$\mathrm{NO}_{2}$

Radioactive

gases
10

23

160,000

(a) Based on the following assumptions:

1. Unspecified mixture of radioactive iostopes released from nuclear plant (most restrictive assumption based on $1 \mathrm{mrem})$.

2. Compliance with $0.5 \%$ by weight sulfur content for $0 i 1$.

3. Air volume of Los Angeles County was assumed to be $3,165 \mathrm{~km}^{3}$, which implies a mean inversion height of $300 \mathrm{~m}$.

4. Ventilation of this volume requires 1 day.

5. Effluent volume rate for 1,000-MWe reactor is taken as $0.5 \times 10^{6} \mathrm{cfm}$ which is an estimated upper limit. 


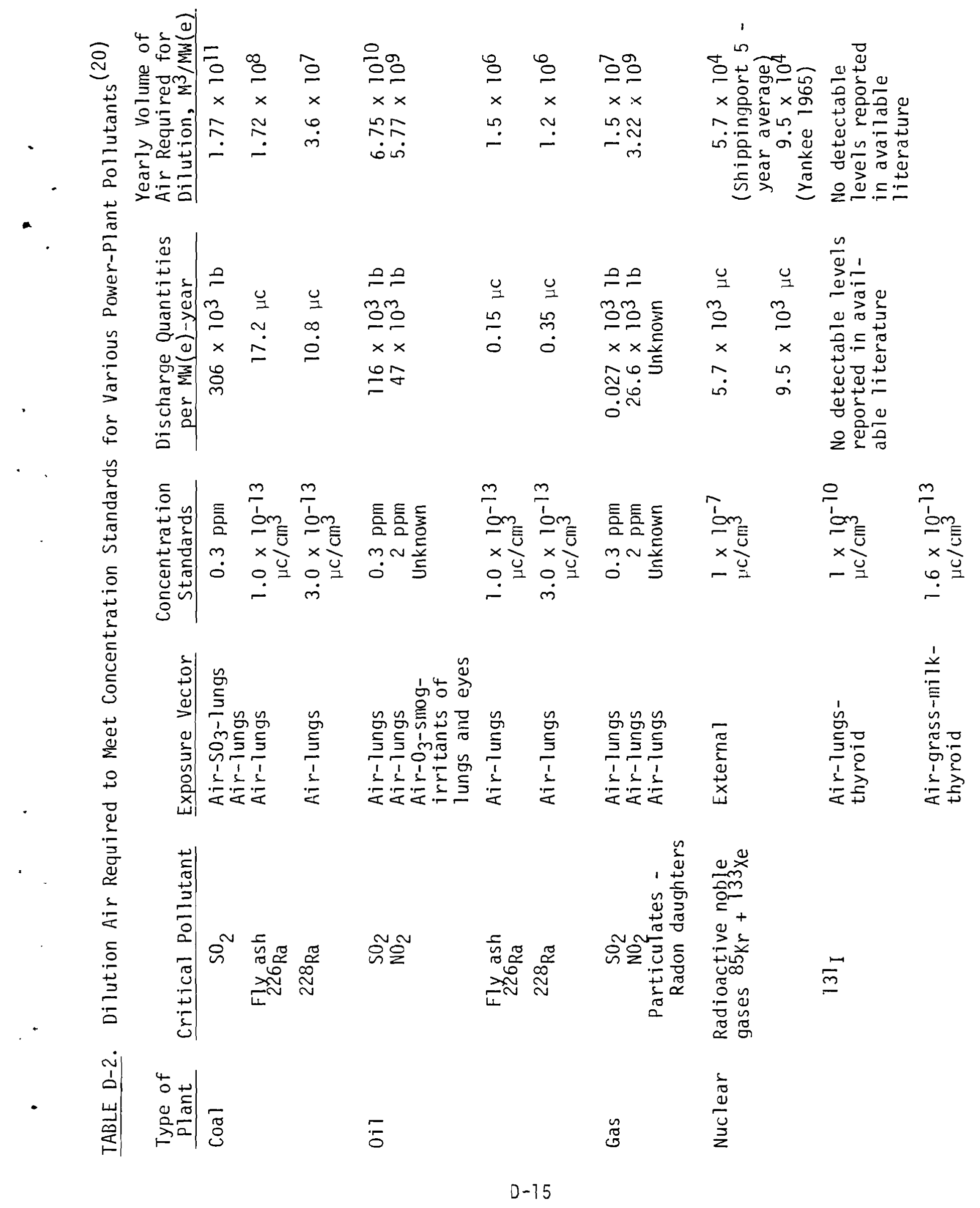


Schikarski et a1. (21) compared coal-fired power plants with nuclear power plants by calculating the dispersion of pollutants and comparing the resulting concentrations to the allowable ambient standards. On this basis, they concluded that nuclear energy systems are "better" than coal by a factor of 180 .

Overal1 Risk

Risk $^{(a)}$ assessment has been used by Hull ${ }^{(18)}$, Starr et a1. $(23,24,25,26)$, Lave et a1. $(27,28,29,30,31)$, Comar and Sagan ${ }^{(32)}$ and others to compare energy technologies. These investigators have estimated the mortality risks associated electric power production activities: mining, fuel preparation, fuel transportation, and fuel use.

Hul1 (18) reported that: "The risk from the highest radiation levels of a few millirems per year to an individual living adjacent to the boundary of a nuclear reactor site seems trivial in comparison with the many risks seldom taken into consideration by the populace." See Table D-3 in support of his conclusions.

Starr et a1. (18) report the results shown in Table D-4. The mortality estimates for the oil-fired power plant are based upon effects caused by sulfur oxides and particulates. The mortality risk was calculated as follows:

$$
M=400(\bar{S} \bar{P} t)^{1 / 2}
$$

where

$M$ is excess mortality per 10 million people,

$S$ is sulfur dioxide concentration, in ppm,

$P$ is suspended particulate concentration, in $\mathrm{g} / \mathrm{m}^{3}$,

$t$ is exposure time, in years, and

The bars indicate mean values over the time $t$.

(a) Defined as the probability of an event times the consequences of the same event. The continuous emission of effluents from the normal operation of power plants and other facilities represents a special case where the probability of the event is 1 . In this case the risk is equal numerically to the consequences of the event. 
TABLE D-3. Annual Probability of Fatal Injury from Radiation and Other Causes (18)

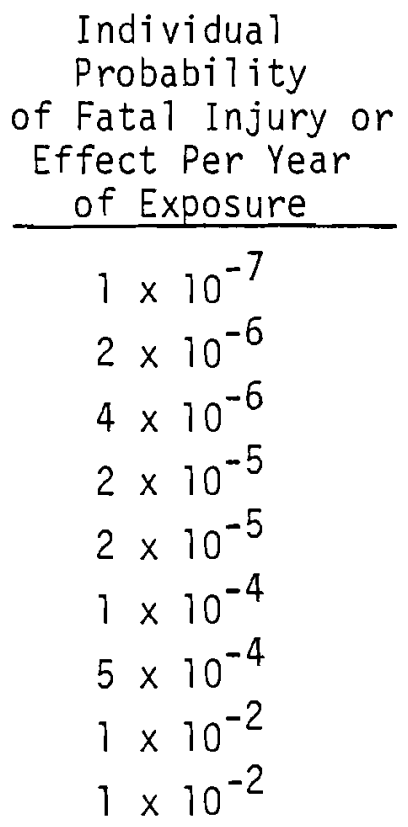

(a) Estimated from ICRP data, which are based on the conservative assumption that effects observed at higher levels (100 rems) are linear with decreasing dose and dose rate.

(b) Based on entire population exposured 100\% of the time.

(c) Based on smoking at a continuous rate.

TABLE D-4. Public Risk Comparison Expected Annual Averages (Deaths per 10 million population per 1000-Mwe plant per year)

Continuous Operation Total Risk

Plant at Regulated Exposure from Type Limits

Accidents

Nuclear

Reactor

(Cancer

Deaths)

1

Negligible

(0.00006)

0il Fired

Plant

(Respiratory Deaths)

60

Negl igible

(0.0002) 
Lave et al. $(27,31)$ have assessed the order of desirability for power plants:

$\begin{gathered}\text { PRESSURIZED } \\ \text { WATER } \\ \text { REACTOR }\end{gathered} \quad \begin{gathered}\text { BOILING } \\ \text { WATER } \\ \text { REACTOR }\end{gathered}>$ OIL $>\quad$ COAL

MORE DESIRABLE

LESS DESIRABLE

Accident statistics were used to estimate mortality risk for mining, transportation and other activities. The effect of chemical effluents from fossil-fueled power plants were estimated from available data. They did not consider gas-fired power plants, and used only sulfur dioxide and particulate matter as the relevant pollutants for the oil- and coal-fired power plants. The following regression relationship, which explains $83 \%$ of the total variation, was used to estimate mortality rates:

$$
\begin{aligned}
M R_{i} & =19.607+0.041 \text { mean } P_{i}+0.071 \min S_{i} \\
& +0.001 P / M_{i}^{2}+0.041 \% N_{i}+0.687 \% \geq 655_{i}+e_{i}
\end{aligned}
$$

where

$M R_{i}$ is total mortality rate (per 10,000 people) in city $i$, mean $P_{i}$ is arithmetic mean of suspended particulate readings in city $i$, min $S_{i}$ is smallest biweekly sulfate reading in city $i(x 10)$,

$P / M_{i}^{2}$ is population density in city $i$,

$\% \mathrm{NW}_{i}$ is proportion of the population which is nonwhite in city $i(X 10)$, $\% \geq 65_{j}$ is proportion of the population 65 and older in city $i(x 10)$, and $e_{i}$ is error term for variation in the mortality rate not explained by the equation.

Lave et al. used this expression to estimate how changes in mortality rates might be caused by the different variables of the equation. This sensitivity analysis showed that a $10 \%$ increase in air pollution (sulfates and particulate matter) would result in $0.90 \%$ increase in the mortality rate.

Sagan and Comar (32) have tabulated the health effects risks for energy technologies. Table D-5 provides a summary of their results. 
TABLE D-5. Quantitative Assessments of Health Effects in the General Population Associated with Electricity Production (all Values Rounded)

\begin{tabular}{|c|c|c|c|c|}
\hline \multirow{2}{*}{\multicolumn{2}{|c|}{$\begin{array}{l}\text { Premature Deaths/yr/ } \\
\text { 1000-MWe Plant } \\
\text { Added Risk/yr(a) }\end{array}$}} & \multirow{2}{*}{$\begin{array}{l}\text { Coal and } 0 i 7 \\
\text { in } 10,000\end{array}$} & \multirow{2}{*}{$\begin{array}{c}\text { Natura] Gas } \\
0 \\
0\end{array}$} & \multirow{2}{*}{$\begin{array}{c}\text { Nuclear } \\
\begin{array}{c}0.01-0.2 \\
\text { in } 5,000,000\end{array}\end{array}$} \\
\hline & & & & \\
\hline Age & $\begin{array}{l}\text { Norma1 Risk } \\
\text { of Death/yr }\end{array}$ & \multicolumn{3}{|c|}{$\begin{array}{c}\text { Enhanced Risk of Death Per Year Bacause } \\
\text { of Electricity Production }(a)\end{array}$} \\
\hline $\begin{array}{c}10 \\
25 \\
45 \\
65 \\
\text { A11 ages }\end{array}$ & $\begin{array}{l}1 \text { in } 3800 \\
1 \text { in } 700 \\
1 \text { in } 200 \\
1 \text { in } 40 \\
1 \text { in } 100\end{array}$ & $\begin{array}{l}1.38 \text { in } 3800(\mathrm{~b}) \\
1.07 \text { in } 700(\mathrm{~b}) \\
1.02 \text { in } 200(\mathrm{~b}) \\
1.004 \text { in } 40 \\
1.01 \text { in } 100\end{array}$ & $\begin{array}{l}1 \text { in } 3800 \\
1 \text { in } 700 \\
1 \text { in } 200 \\
1 \text { in } 40 \\
1 \text { in } 100\end{array}$ & $\begin{array}{l}1.0008 \text { in } 3800 \\
1.0001 \text { in } 700 \\
1.00004 \text { in } 200 \\
1.000008 \text { in } 40 \\
1.00002 \text { in } 100\end{array}$ \\
\hline \multicolumn{2}{|c|}{$\begin{array}{l}\text { Number of premature } \\
\text { deaths in } 30 \text { yr } \\
\text { associated with } \\
\text { routine operation } \\
\text { of } 300 \text { plants }(\mathrm{c}) \\
\text { Number of deaths } \\
\text { statistically pre- } \\
\text { dicted from cata- } \\
\text { strophic accidents in } \\
30 \text { yr from } 300 \text { plants } \\
\text { (Rasmussen estimate)(d) }\end{array}$} & $\begin{array}{l}20,000 \text { to } \\
1,000,000\end{array}$ & 0 & $\begin{array}{l}100 \text { to } \\
2,000\end{array}$ \\
\hline
\end{tabular}

(a) Upper estimates.

(b) These estimates are undoubtedly quite high because premature deaths from fossil fuel combustion products fall aimost exclusively in the older age groups.

(c) This represents the total operation for a generation of power plants that would supply about $300 \mathrm{milli}$ ion people.

(d) Based on 1 chance in $10^{6}$ of an accident per reactor-year causing 1000 immediate and delayed casualties. WASH-1400 U.S. AEC, 1974. 
Environmental Impact

Beall et al. (33) and Battelle, Pacific Northwest Laboratory (PNL) (34) have developed methodologies for assessing the overall impact of energy technologies. Beal et al. developed the following impact index:

$$
Q_{j}=\sum_{i=1}^{m} \lambda_{i} g_{i j}+\sum_{i=m+1}^{n} \lambda_{i} h_{i j}
$$

and

$$
\sum_{i=1}^{n} \lambda_{i}=100
$$

where

$Q_{j}$ is impact index of energy alternative $j$,

$\lambda_{j}$ is relative importance value assigned to account $i$,

$g_{i j}$ is impact severity measure assigned to environmental account $i$ for for energy alternative $j$, and

$h_{i j}$ is impact severity measure assigned to economic account $i$ for a)ternative $j$.

The impact index is the sum of an environmental and an economic impact. The environmental account components are land, water, air, solid or stored waste and deaths and injuries. The economic account components are resource consumed, capital costs, fuel costs and operating costs.

The relative importance values $(\lambda)$ have been defined as a "conceptual device that recognizes both the existence of multiple objectives and differential relative importance of satisfying them." The values assigned to the economic and environmental accounts must total 100, and should reflect the community's preference regarding its willingness to accept certain environmental damages in return for certain economic benefits. An assessor might choose equal values of 50 for the environmental and economic accounts. Within the 50 points of the environmental account, he might assign 5 points to land, 10 to water, 20 to air, 5 to waste, and 10 to deaths. For the economic account, he might distribute the importance factors as follows: 10 points for resource consumed, 15 for capital cost, 15 for fue 1 cost, and 10 for operating costs, again making a total of 50 points. 
The impact severity value $\left(g_{i j}, h_{i j}\right)$ is designed to reflect the differential gain or reduction of an impact element from a reference energy source in the evaluation system. A reference energy source has been included because the comparison of values will give a better evaluation of the beneficial and adverse impacts of the alternative energy sources. The reference energy source thus becomes the basis for expressing the trade-offs among the energy alternatives being considered. The reference energy source can be any energy source. If the alternative source has the same impact as the reference energy source, then the impact severity will be equal to zero. The comparison is made by dividing the value of the reference source into the difference between the sources; that is:

\section{$\frac{\text { Reference source value - alternative source value }}{\text { Reference source value }}$}

If the alternative is beneficial, by having less impact than the reference source, the impact severity will be position and vice versa. The impact severity scale to be used in the evaluation of individual impacts is shown below:

Adverse Impact

Beneficial Impact

\begin{tabular}{ccccccccccc}
-10 & -8 & -6 & -4 & -2 & 0 & +2 & +4 & +6 & +8 & +10 \\
Extreme & $\begin{array}{c}\text { Very } \\
\text { high }\end{array}$ & High Some & Low None Low Some High $\begin{array}{c}\text { Very } \\
\text { high }\end{array}$ & Extreme \\
& \multicolumn{1}{c}{ IMPACT SCALE } & &
\end{tabular}

PNL. ${ }^{(34)}$ developed the following environmental index for ranking energy systems:

$$
I_{i}=\Sigma_{m} W_{m_{i}} \Sigma_{n} W_{n} \Sigma_{p} W_{p} Q_{p}
$$

where

$I_{j}$ is Environmental index for energy system $i$

$w_{m_{i}}$ is weight of module $m$ in system $i$

$W_{n}^{i}$ is Weight of environmental component $n$ 
$W_{p}$ is Weight of parameter $p$

$Q_{p}$ is Quantity of $p$ produced per unit of energy.

This method is based upon earlier Battelle work by Whitman et al. (10) and involves a .hierarchy of environmental burdens under four major categories (modules): ecology, esthetics, environmental pollution and human interest. Each of these modules is divided into environmental components, which in turn can be separated into environmental parameters. For the energy assessment work only the environmental pollution module was developed. Five environmental components are considered: air, water, solid waste, land use and radiation.

Environmental standards and other data are used to derive the weighting factors $\left(W_{p}\right)$. For air pollutants, oxides of nitrogen were arbitrarily assigned a weighting factor of 1 . The weighting factors for the other gaseous pollutants are calculated from the ratio of the air quality standards. For example, the weighting factor for sulfur oxides is:

$$
W_{S O}=\frac{N O_{x} \text { Standard }}{\text { SO }_{x} \text { Standard }}=\frac{700 \mu g / \mathrm{m}^{3}}{80 \mu \mathrm{g} / \mathrm{m}^{3}}=1.25 .
$$

Similar methods are used to develop weighting factors for other parameters in the environmental pollution module.

Economic Impact

Many researchers $(35-42)$ have sought to use the dollar as the common denominator for comparing energy technologies. This approach is the most complex in that it requires quantification of the environmental effects and cost of these effects to society. Budnitz and Holdren ${ }^{(35)}$ review the methods available for estimating social and environmental costs of energy technologies. They note that dollar values provide a common denominator for all consequences; provides a method of comparing "apples and oranges." However, assigning dollar values to the various effects is not without problems; for instance, those aspects easiest to quantify may not be the most important ones at a 11 . Budnitz and Holdren state that such comparisons should be approached with the utmost cuation, and particular attention should be paid to the motivation for the comparison and the use to which it is put. 
Lave and Silverman (36) provide a review of how environmental impacts and costs can be incorporated into economic theory and models. They also summarize the literature that quantifies these social costs.

Hub et a . (37) used a cost-risk-benefit model to compare energy technologies. They quantified the investment and operating costs and social benefits of energy production and calculated the external costs of the energy production: natural resource consumption (air, water and 1 and), property resources (buildings, equipment, personal goods, etc.) and human resources (lost work time, medical costs and pain and anguish). Sulfur dioxide and particulate matter were the only chemical effluents considered in the study. Health effects were converted to economic terms by assuming a value of $\$ 50$ per man-day lost.

Brewer et a. $(38,39)$ extended the work of Hub et a 1 . and developed comparative data for alternative fuel cycles normalized to the production of 6.57 billion kWhe or to a generating capacity of 100 MWe. The results are given in Table D-6. The impacts and costs are described in four groups: conventional costs, consumption of nonrenewable fuel resources, environmental degradation and impacts on human health and safety.

Beller ${ }^{(40)}$ presents an analytical approach for assessing energy technologies and policies. Reference Energy Systems (RES) are defined for nuclear fuels (U-235 and U-238), hydropower, geothermal, and fossil fuels (coal, oil and natural gas). The RES has an integrated data base covering the environmental, economic and resource aspects of the system. The model is intended for a national scope and it projects the impact of energy use to the year 2020. A demand model is used to estimate the energy use scenario. Chemical effluent rates are projected for the future but no attempt is made to assess the resulting health and welfare effects or costs. Only capital and operating costs for the various energy systems and control technologies are considered.

S. M. Barrager et a1. $(41,42)$ present a method for extending economic comparisons of nuclear and coal-fired electric power to include health, safety and environmental impacts. They assign dollar values to the consequences of reactor accidents or health effects from air pollution. The values are not 


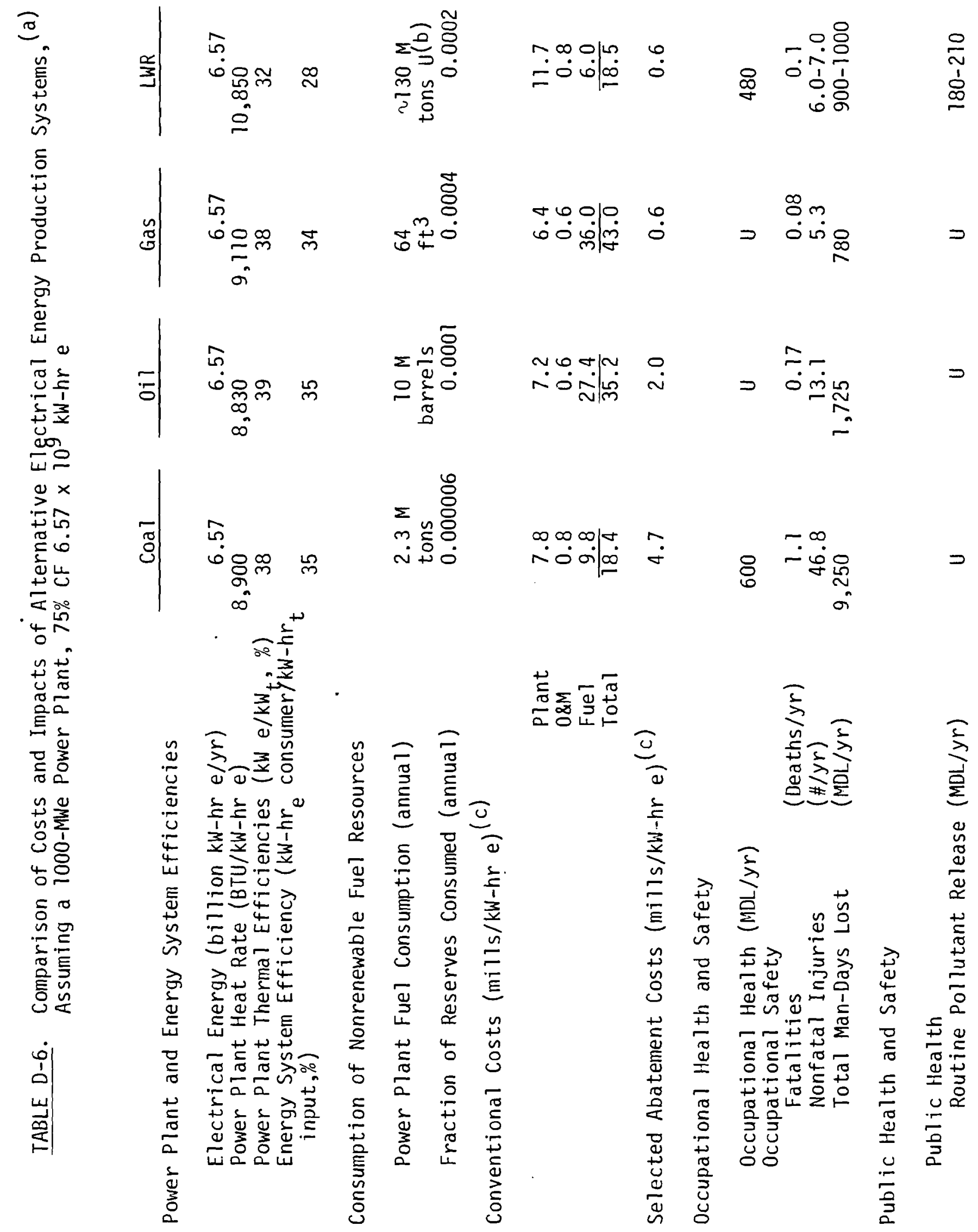




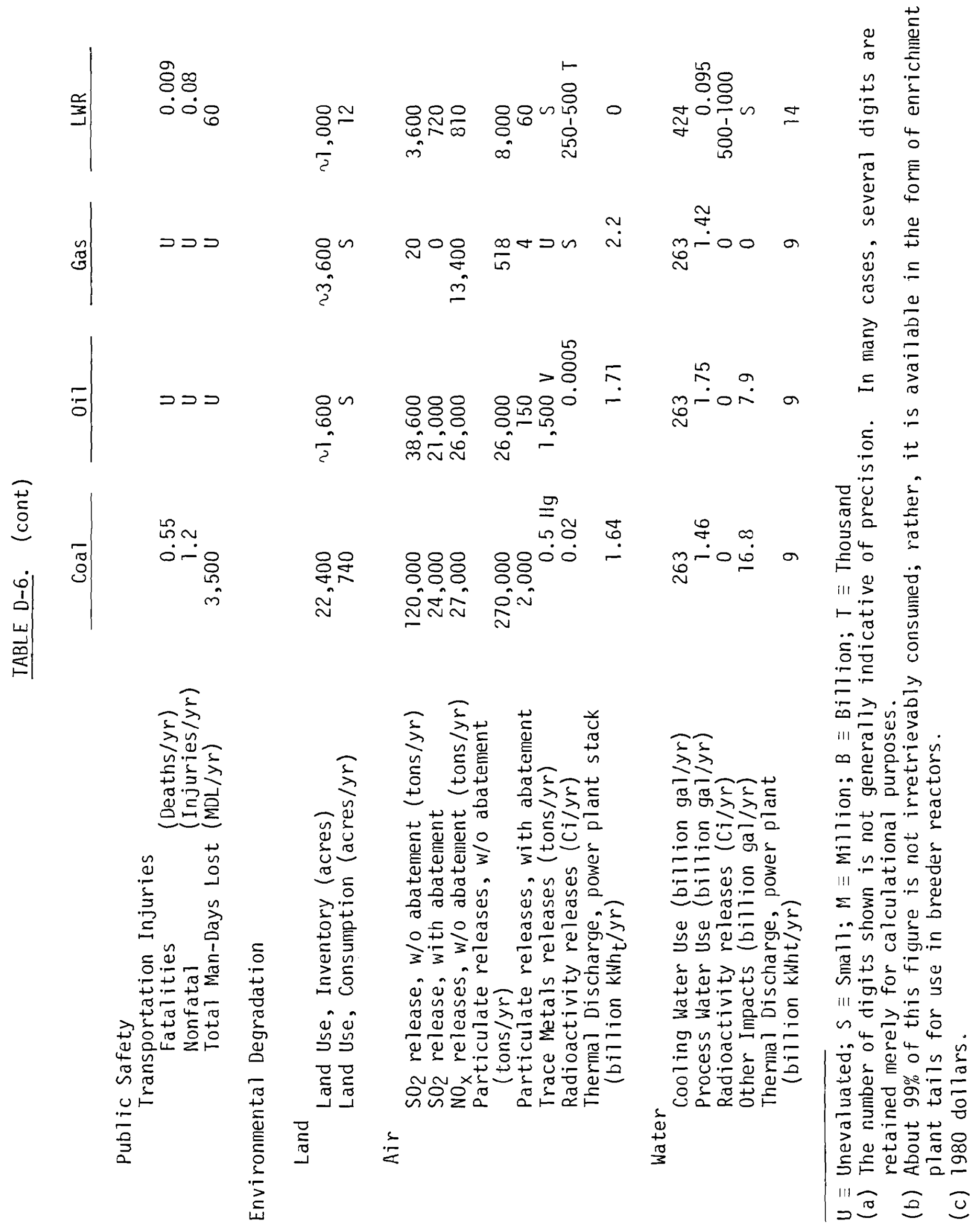


intended as objective measurements of the value society places on lives or sickness but rather how much society is willing to pay to reduce the risk. Barrager et a1. identify the external (social) costs in the nuclear and coal fuel cycles and express them in mills per killowatt hour. These costs are then summed to compare the total social costs of the two technologies.

\section{EVALUATION OF ASSESSMENT METHODOLOG.IES}

This section provides the justification for the assessment methodology described in the report. The chemical effluent assessment methodology has four main requirements. It must:

- identify any effluents which exceed environmental standards

- estimate the control required for each source

- assess the impact of chemical effluents for which no environmental standards exist and identify any potentially hazardous chemicals

- determine the ranking of chemical effluents emitted from each nuclear fuel cycle facility.

The suitability of any methodology must be determined in relation to these requirements--the premise being that human health must be protected from hazardous chemicals. An accurate assessment requires exposure-doseresponse information for each chemical and combinations of chemicals. This information is not presently available. For many chemicals the critical pathways for human exposure have not been defined. Environmental quality standards are therefore developed with less than complete information. These standards are based on laboratory tests on animals, occupational exposure data, professional judgment and other factors. Since present and future nuclear fuel cycle facilities must comply with such standards, the standards shouid be used as the main criteria for meeting the above requirements. Furthermore, the method should be able to estimate acceptable levels for chemicals that do not have environmental standards. This will ensure that the 30- to 100-yr modeling periods selected for this project will have more realistic inputs regarding environmental control requirements. 
None of the methods reviewed are designed to meet the specific needs of this project. They all fail to meet one or more of the requirements. However, the following references do describe techniques which may be used in part to develop a suitable methodology:

- Eimutis et a1. $(12,13)$ compare the concentration of a chemical to its environmental standard to determine its degree of hazard. This approach provides a method for ranking the various chemical effluents.

- Handy and Schindler ${ }^{(14)}$ describe methods for estimating acceptable concentrations of chemicals. This technique may be used for chemicals that presently do not have environmental quality standards.

- Whitman et al. ${ }^{(10)}$ and others at PNL ${ }^{(34)}$ describe methods for weighting the importance of various effects and summing of parts to assess the total effect. This summation approach can be used to evaluate situations with several chemicals present simultaneously. 


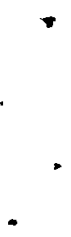

$-$ $-$ 


\section{REFERENCES}

1. Scientific and Technical Assessment Report on Particulate Polycyclic Organic Matter, EPA 600/6-75-001, U.S. Environmental Protection Agency, Research Triangle Park, NC 27711, March 1975.

2. Scientific and Technical Assessment Report on Manganese, EPA 600/6-75-002, U.S. Environmental Protection Agency, Research Triangle Park, NC 27711, July 1975.

3. Scientific and Technical Assessment Report on Cadmium, EPA 600/6-75-003, U.S. Environmental Protection Agency, Research Triangle Park, NC 27711, July 1975.

4. Scientific and Technical Data Base for Criteria and Hazardous Pollutants-1975 ERC/RTP Review, EPA 600/1-76-023, U.S. Environmental Protection Agency, Research Triangle Park, NC 27711, January 1976.

5. Review of Research Related to Sulfates in the Atmosphere, Subcommittee on the Envirorment and the Atmosphere, U.S. House of Representatives, Ninety-Fourth Congress, U.S. Government Printing Office, Washington, DC, April 1976.

6. Health Consequences of Sulfur Oxides: A Report from CHESS, 1970-1971, EPA 650/1-74-004, U.S. Environmental Protection Agency, Research Triangle Park, NC 27711, May 1974.

7. L. Leopold, et al., A Procedure for Evaluating Environmental Impacts, U.S. Geological Survey Circular G45, Washington, DC, 1971.

8. M. Bender and S. Ahmed, Index of the Composite Environment: A Basis for or Evaluating Environmental Effects of Electric Power Generating Plants in Response to NEPA, Report ORNL-TM-4492, Oak Ridge Nationa1 Laboratory, Oak Ridge, TN, 1974.

9. M. L. Warner adn E. N. Preson, Review of Environmental Impact Assessment Methodologies, Battelle Columbus Laboratories, U.S. Environmental Protection Agency, Report EPA 600/5-74-002, Research Triangle Park, NC, April 1974.

10. I. L. Whitman, et al., Design of an Environmental Evaluation System, Batte1le Columbus Laboratories, Report PB-201 743, National Technical Information Service, Springfield, VA 22151, June 1971.

11. P. F. Fennelly, et a1., Environmental Assessment Perspectives, EPA Report 600/2-76-069, U.S. Environmental Protection Agency, Research Triangle Park, NC, 27711 , March 1976. 
12. E. C. Eimutis, Source Assessment: Prioritization of Stationary Air Pollution Sources Model Description, EPA Report 600/2-76-032a, Research Triangle Park, NC 27711, February 1976.

13. E. C. Eimutis, B. J. Holmes and L. B. Mote, Source Assessment: Severity of Stationary Air Pollution Sources--A Simulation Approach, EPA Report 600/2-76-032e, Research Triangle Park, NC 27711, July 1976.

14. R. Handy and A. Schindler, Estimation of Permissible Concentrations of Pollutants for Continuous Exposure, EPA Report 600/2-76-155, U.S. Environmental Protection Agency, Research Triangle Park, NC 27711, July 1976.

15. M. Eisenbud and H. G. Petrow, "Radioactivity in the Atmospheric Effluents of Power Plants that Use Fossil Fuels," Science, 144, 288-289, 1969.

16. J. E. Martin, E. D. Harward and D. T. Oakley, "Comparison of Radioactivity from Fossil Fuel and Nuclear Plants," In: Hearings on Effects of Producing Electric Power, Vol. 1, 91st U.S. Congress, lst Session, Joint Committee on Atomic Energy, Superintendent of Documents, U.S. Government Printing Office, Washington, DC, 1969, p. 773-809.

17. Z. Jaworowski, et al., "Radiation Hazards to Population from Conventional and Nuclear Production," In: Symposium on Environmental Surveillance Around Nuclear Installations, Vol. 1, International Atomic Energy Agency, IAEA-SM-180/20, Warsaw, Poland, 1973, p. 403-412.

18. A. P. Hull, "Radiation in Perspective: Some Comparisons of the Environmental Risks from Nuclear- and Fossil-Fueled Power Plants," Nuclear Safety, 12, 185-196, 1971 .

19. A. P. Hul1, "Comparing Effluent Releases from Nuclear and Fossil-Fueled Power Plants," Nuclear News, 17, 51-55, 1974.

20. J. G. Terril, Jr., E. D. Harward and I. P. Leggett, Jr., "Environmental Aspects of Nuclear and Conventional Power Plants," Ind. Med. Surg., 36, $412-419,1967$.

21. W. Schikarski, P. Jansen and S. Jordon, "An Approach to Comparing Air Pollution from Fossil-Fuel and Nuclear Power Stations," In: Symposium on Environmental Aspects of Nuclear Power Stations, International Atomic Energy Agency, IAEA-SM-146/57, New York, 1970.

22. C. Starr, M. A. Greenfield and D. F. Hausknecht, "A Comparison of Public Health Risks: Nuclear or 0il-Fired Power Plants," Nuclear News, 15, $37-45,1972$.

23. C. Starr, "General Philosphy of Risk-Benefit Analysis," In: Energy and the Environment: A Risk-Benefit Approach, Pergamon Press, Inc., Elmsford, NY 10523, 1976. 
24. C. Starr and M. A. Greenfield, "Public Health Risks of Thermal Power Plants," Nuclear Safety, 14, 267-274, 1973.

25. C. Starr, "Social Benefits Versus Technological Risk," Science, 165, $1232-1238,1969$.

26. C. Starr, M. A. Greenfield and D. F. Hausknect, "Comparison of Public Health Risks: Nuclear and 0i1-Fired Power Plants," Nuclear News, 15, $37-45,1972$.

27. L. B. Lave and L. C. Freeburg, "Health Effects of Electricity Generation from Coal, 0i1 and Nuclear Fuel," Nuclear Safety, 14, 409-429, 1973.

28. L. B. Lave, "Air Pollution Damage: Some Difficulties in Estimating the Value of Abatement," In: Environmental Quality Analysis, John Hopkins Press, Baltimore, MD, p. 203-242, 1972.

29. L. B. Lave and E. P. Seskin, "Air Pollution and Human Health," Science, Vol. 169, No. 3947, p. 723-733, August 21, 1970.

30. L. B. Lave and E. P. Seskin, "Health and Air Pollution," Swedish Journal of Economics, No. 1, p. 76-95, 1971.

31. L. B. Lave, "Health Effects of Electricity Generation from Coal, $0 i 1$ and Nuclear Fue 1," In: Energy and the Environment: A Risk-Benefit Approach, Pergamon Press, Inc., Elmsford, NY 10523, 1976.

32. C. L. Comar and L. A. Sagan, "Health Effects of Energy Production and Conversion," Annual Review of Energy, 1, p. 581-600, 1976.

33. S. E. Bea11, et a1., An Assessment of the Environmental Impact of Alternative Energy Sources, Report ORNL-5024, Oak Ridge Nationa 1 Laboratory, Oak Ridge, TN 37830, September 1974.

34. Environmental Considerations in Future Energy Growth, EPA 600/4-73-004, J.S. Environmental Protection Agency, Research Triangle Park, NC 27711 , March 1973.

35. R. J. Budnitz and J. P. Holdren, "Social and Environmental Costs of Energy Systems," Annual Review of Energy, 1, p. 553-580, 1976.

36. L. B. Lave and L. P. Silverman, "Economic Costs of Energy-Related Environmental Pollution," Annual Review of Energy, 1, p. 601-628, 1976.

37. K. A. Hub, et al., Social Costs for Alternative Means of Electrical Power Generation for 1980 and 1990, ANL-8093, Argonne Nationa 1 Laboratory, Argonne, Il]inois, 1973. 
38. S. T. Brewer, et a1., Comparative Risk-Cost-Benefit Study of Alternative Sources of Electrical Energy, U.S. Atomic Energy Commission, WASH-1224, Washington, DC, December 1974.

39. S. T. Brewer, "Quantification and Comparison of External Costs of Nuclear and Fossil Electrical Power Systems," In: Energy and the Environment: Cost-Benefit Analysis, Pergamon Press, Inc., Elmsford, NY 10523, 1976.

40. M. Beller (editor), Sourcebook for Energy Assessment, BNL 50483, Brookhaven National Laboratory, Brookhaven, NY, December 1975.

41. S. M. Barrager, B. R. Judd and D. W. North, The Economic and Social Costs of Coal and Nuclear Electric Generation, Report NSF 76-501, National Science Foundation, Washington, DC 20550, March 1976.

42. S. M. Barrager, B. R. Judd and D. W. North, "Decision Analysis of Energy Alternatives: A Comprehensive Framework for Decision-Making," In: Energy and the Environment: Cost-Benefit Analysis, Pergamon Press, Inc., Elmsford, NY 10523, 1976. 


\section{DISTRIBUTION}

No. of

Copies

\section{OFFSITE}

1

A. A. Churm ERDA Chicago Patent Group U.S. Energy Research and Development Administration Argonne, IL 60439

27 ERDA Technical Information Center
A. F. Kluk
Division of Environmental
Control Technology
Germantown, MD 20767
J. L. Liverman
Office for the Assistant
Administrator of Environment
and Safety
Germantown, MD 20767
W. E. Mott
Division of Environmental
Control Technology
Germantown, MD 20767

No. of

Copies

\section{ONSITE}

\section{ERDA Richland Operations Office}

H. Ransom

W. Burns

46 Battelle-Northwest

R. L. Aaberg

D. L. Brenchley (10)

N. E. Carter

D. B. Cearlock

R. M. Fleischman

J. C. Fox

A. J. Haverfield

C. M. Heeb

D. L. Hesse1

T. J. Kabele (5)

H. V. Larson

R. C. Liikala

J. A. McNeese

J. M. Nielsen

T. B. Powers

K. J. Schneider

C. L. Simpson

J. K. Soldat

B. E. Vaughan

E. C. Watson (5)

W. R. Wiley

L. D. Williams

Technical Information Files (5)

Technical Publications (1) 
$-$

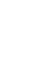

$\checkmark$

-

$\checkmark$

$+$

,

$\checkmark$ 